\title{
OBED HUSSEY
}

\author{
WHO, OF ALL INVENTORS, \\ MADE BREAD CHEAP
}

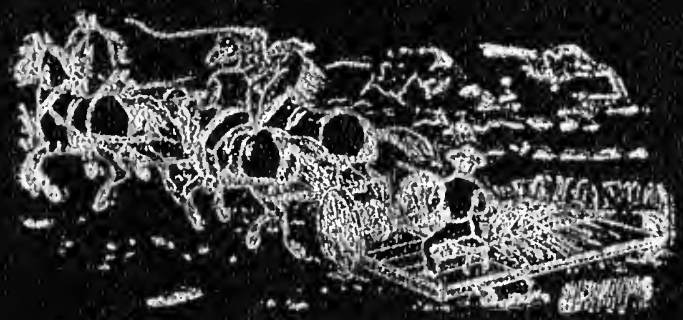



Digitized by the Internet Archive in 2007 with funding from Microsoft Corporation 






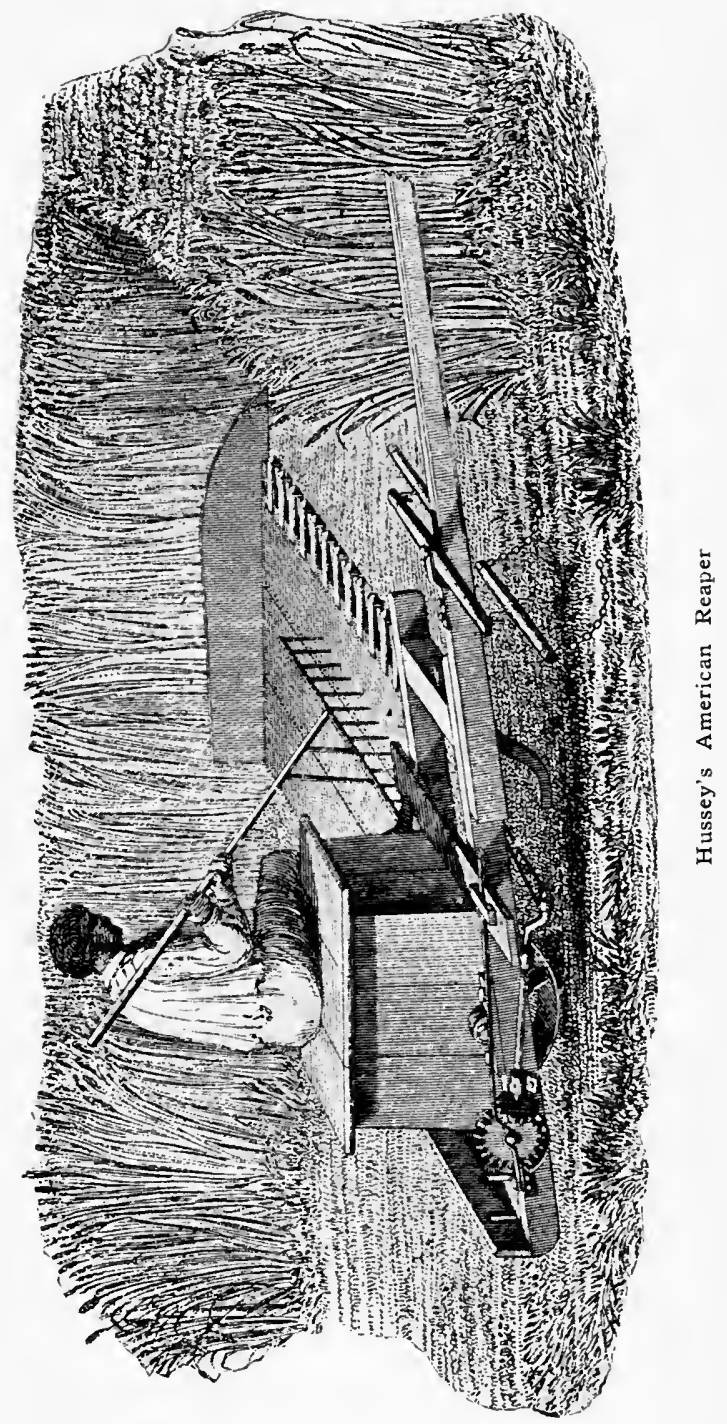




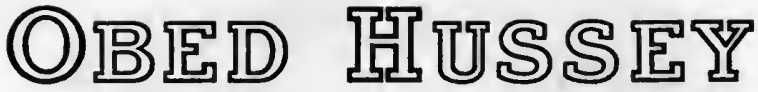

\section{WIO, OF A几匹 INWENTORS \\ MADE BREAD C REAP}

\author{
\&
}

Being a true record of his life and strugsles to introduce his greatest invention, the reaper, and its success, as gathered from pamphlets published heretofore by some of his friends and associates, and reprinted in this volume, together with some additional facts and testimonials from other sources.

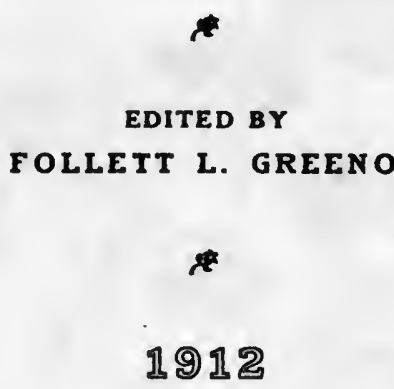




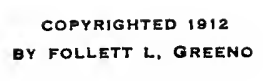




\section{PREFACE}

G VERY STEP in the progress of modern achievement has been met with strong resistance and hostile contest. There is in business an actual firing line where continuous conflict wages, and so fierce does the struggle become that it requires a certain class of men possessing qualities, not only of energy and perseverance, but of tenacity and combativeness, aggressive and determined to fight to the last ditch for commercial supremacy. Such men do not always rely upon the merits of their cause, nor do they stop to question the justice or injustice of their methods. They have but one goal, commercial supremacy, and every effort is bent and every man and method utilized to attain that end.

Men of inventive genius are rarely of that type. They are more often unassuming and averse to anything like a personal combat. Such a man was Obed Hussey, inventor of the reaper. Honest and conscientious, enured to hard and unremitting toil, with the inspiration of a new idea for the benefit of mankind burning in his brain, he applied himself in the face of immense difficulties to the production and perfection of the great gift which he gave to the world. He was a man at once so humble and so broad in his kindness, so loyal to his 
Quaker ideals of righteousness and justice, that he offered no protests, or arguments against his rivals and opponents other than the superiority of his own machine. Only his great genius which produced the superior machine (a fact which no one could possibly contradict) could have saved him from the fierce opposition of his more powerful rivals. One has only to read from some of his own letters reproduced in this narrative, to witness the fairness of his attitude, or to gain a knowledge of his scruples.

Yet it was just this which has operated to deprive Obed Hussey of his well deserved fame as inventor of the reaper. Moreover, a great industry, fostered by his opponents in the patent controversy, has grown up, the basis and life of which is Obed Hussey's invention of the reaper. It would seem that the vast fortunes made from this industry should be ample reward for those who are receiving the benefits of a man's life work without whose genius it would never have been.

In 1897 there was published in Chicago a booklet entitled "A Brief Narrative of the Invention of Reaping Machines," a large part of which is reproduced in this book. The pamphlets of which the narrative was a republication were from the pen of Edward Stabler, an able man and a mechanic of great skill and 
ability, a close friend of Mr. Hussey and one familiar with his reaper and with all the facts which he set forth in these articles. Such other facts and information as are published herein were furnished by Martha Hussey, daughter of Mr. Hussey, now living and by my uncle, Hon. Alexander B. Lamberton, who married Mr. Hussey's widow. Mr. Lamberton is a man of high standing, having for many years taken an active part in the affairs of Rochester. He was President of the Rochester Chamber of Commerce, 1901-1904 (three successive terms), and has been President of the Rochester Park Board for the past eleven years. He also won national fame as a hunter and naturalist and was President of the $\mathrm{Na}$ tional Association for the Protection of Fish and Game. His relation to the Hussey family has made him conversant with the whole history of the invention of the reaper and of $\mathrm{Mr}$. Hussey's early struggles.

The facts as set forth in this volume are well known to the reaper men of the United States, men high up in the industry. Had Mr. Hussey lived, he would have been able to establish his claim to the invention of the reaper beyond the shadow of a doubt. This humble man, who, against tremendous odds and powerful opposition, proved his contentions before Congress and the United States 
Patent Office could certainly have won deserved fame with the public.

His tragic death, which came just at the time when his Congressional victory was certain and the future of his reaper seemed bright with promise, occurred while he was en route from Boston to Portland, Maine, on August 4, 1860. In those days there was often no water in the cars. The train had stopped at a station when a little child asked for a drink of water and Mr. Hussey stepped out to get it for her. On his return, as he attempted to reenter, the cars started; he was thrown beneath the wheels and instantly killed. The last act of his life was one of kindness and compassion.

Obed Hussey is dead, but his machine still lives, an article of measureless value to the great world of agriculture. His life was one of long suffering and faithful service and he justly deserves the proper credit and honor for his great invention. To Obed Hussey belongs the fame of Inventor of the Reaper as these pages will show, to which purpose these facts are published by those who knew him and his works, and these facts, like his works, stand squarely on their own merits.

FOLLETT L. GREENO.

Rochester, N. Y., April 21, 1912. 



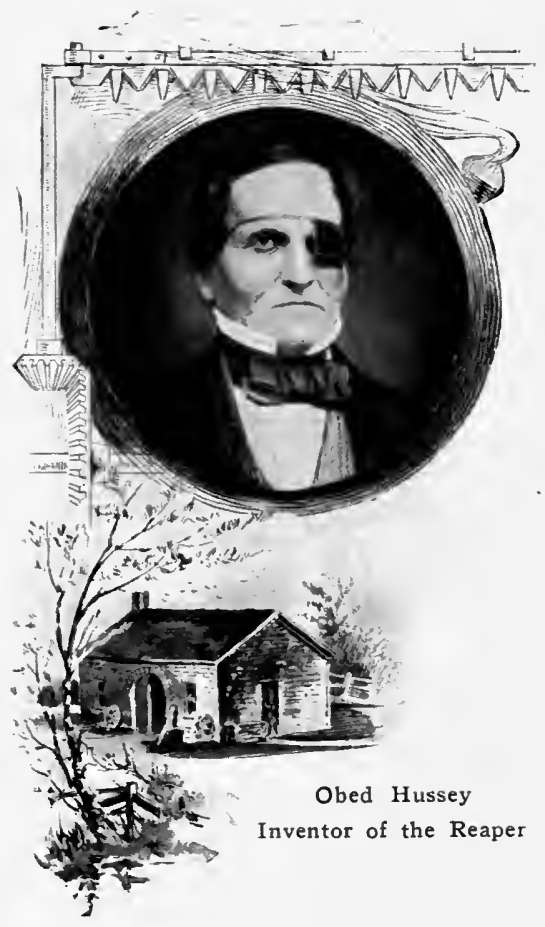




\section{OBED HUSSEY, THE INVENTOR OF THE REAPER}

Obed Hussey was of Quaker stock, born in Maine in 1792 and early removed to Nantucket, Mass. When young, like all Nantucket boys, he had a desire to go to sea, and made one or two whaling voyages. He was of quiet and retiring disposition, studious, thoughtful, with a strong bent for studying intricate mechanical contrivances. Little is known of his early life and there is none living who knew him at that time. He was a skillful draftsman and incessant worker at different inventions all his life. He invented a successful steam plow, for which he obtained a medal in the West. He also invented a machine for grinding out hooks and eyes, a mill for grinding corn and cobs, a husking machine run by horse power, the "iron finger bar," a machine for crushing sugar cane, a machine for making artificial ice, and other devices of more or less note.

His chief characteristic seems to have been an extremely sensitive, modest and unassuming personality. It was this reticence which has served to keep him in the background as the inventor of the reaper. He was unwilling to push himself forward, and his claim to dis- 
tinction has had to rest solely upon the merits of his greatest invention.

Mr. Hussey first began work on his reaper in a room at the factory of Richard B. Chenoweth, a manufacturer of agricultural implements, and the story of those early efforts is told by Sarah A. Chenoweth, a granddaughter of the latter:

Early Efforts

"As a child, it seemed that I had always known Mr. Hussey. I saw him every day of my life, for he lived in a room, the use of which my grandfather, Richard B. Chenoweth, a manufacturer of agricultural implements in Baltimore City, had given him at his factory. No grown person was allowed to enter, for in this room he spent most of his time making patterns for the perfecting of his reaper. I, unforbidden, was his constant visitor, and asked him numberless questions, one of which, I remember, was why he washed and dried his dishes with shavings. His reply was characteristic of himself, 'Shavings are clean.'

"At this time I was about seven years of age, having been born in 1824. Although very poor at the time, he was a man of education, upright and honorable, and so very gentle in both speech and manner that I never knew fear or awe of him. I do not know for a certainty how long he remained there,-several years, at the least, I think, but of his connection with 
the reaper, I am positive, for it was talked of morning, noon and night. To this day, my brother bears on his finger a scar, made by receiving a cut from one of the teeth of the machine. When, finally, the model was com- First pleted, it was brought out into the yard of the Trial factory for trial. This trial was made on a board, drilled with holes, and stuck full of rye straws. I helped to put those very straws in place. Mr. Hussey, with repressed excitement, stood watching, and when he saw the perfect success of his invention, he hastened to his room too moved and agitated to speak. This scene is vividly impressed on my mind, as is also a remark made by a workman, that $\mathrm{Mr}$. Hussey did not wish us to see the tears in his eyes."

The story of Mr. Hussey's efforts at that time is also told by a brother of the little granddaughter:

“Chicago, Nov. 25, 1893.

"Clark Lane, Esq.,

"Elkhart, Ind.

"My Dear Sir:-

'I notice in this morning's 'Inter Ocean' your letter of 22nd in regard to the First Reaper and Obed Hussey; now I can say that the name of Obed Hussey called to my mind the best friend of my boyhood days, as he was in the habit 
of keeping me supplied with pennies when I was short, and taught me how to put iron on a wood sled, and helped me to make my first wagon as he turned the wheel for me. You are right with regard to the date of the fingers and shaped cutters for Reapers, as I saw and handled it, to my sorrow in 1833 or ' 34 before the machine was finished and nearly cut my fingers off. I have the whole thing photographed in my mind and can show the spot or within 10 feet of it where I lay on the floor. It was not possible to try it in Maryland, owing to the hilly nature of the ground, and was afterwards taken to Ohio for trial and was rebuilt there, or at least a part of it, but of that part (the rebuilding) I do not know for a certainty, but the bars, fingers and knives I do most positively remember, as I was a lad of some eight or nine years old with a mechanical turn of mind and was looking into what seemed strange to me, hence I cut my finger so bad that I carried the scar for a number of years. I very distinctly remember the incomplete reaper made by my old friend, Obed Hussey, as it was made in my grandfather's shop in Baltimore, Maryland, who was at that time the leading plow-maker of the U. S. and that it was made either in 1833 or ' 34 , as I would not have had a chance to see it if later than ' 34 as I was not at home until ' 38 , when it had been 
sent, as I was told, to Ohio for trial and some parts had to be rebuilt.

"Please excuse the liberty I have taken in writing to you, but I could not resist the temptation to give my tribute to my old friend, $O$. Hussey.

"Very respectfully yours,

(Signed) "W. H. CHENOWETH."

The machine referred to was, no doubt, the reaper completed and tested near Cincinnati in the harvest of 1833.

It is not known when Mr. Hussey left the Chenoweth factory, but during the winter of The First Reaper 1832-33 he was at Cincinnati working upon the reaper that, more than else, won him lasting fame during the harvest of 1833. The "Mechanics Magazine" for April, 1834, contains an illustration of "Hussey's Grain Cutter." The picture does not represent the model deposited in the Patent Office with his application, for it differs in many essentials from the drawing of the patent, which, of course, corresponded with the model there filed. It has neither divider nor outer wheel, and the construction of the platform differs from that of his regular machine. It is thought that the picture represents the small working model made at the Chenoweth factory, mentioned by the little girl.

Mr. Hussey found one who took an interest in his invention and became so confident of its 
Financing the First

Reaper mechanical facilities for manufacturing a reaper to be tested in the field. This was Jarvis Reynolds, of Cincinnati. Drawings were made of the cutting apparatus and a description of it was sent by the inventor to a friend, Edwin G. Pratt, early in 1833.

Another personal friend of Obed Hussey was Edward Stabler, who lived at Sandy Hill, Maryland, and.was, as he termed himself, "a farmer and a mechanic." That he was a mechanic of ability is evidenced by government seals which were cut by him, that for the Smithsonian Institute being worthy of men-

The tion as an example of his skill. He was a postReaper master from President Jackson's time until his Historian own death. He is the only one who may be said to have acted as Hussey's historian, and has left very much valuable information in the form of letters, legal papers, et cetera. In 1854 and ' 55 he published "A Brief Narrative of the Invention of Reaping Machines," “Hussey's Reaping Machine in England," and "A Review of the Pamphlet of W. N. P. Fitzgerald in Opposition to the Extension of the Patent of Obed Hussey; and also of the Defense, of Evidence in Favor of Said Extention," etc. There is sufficient data obtainable from Mr. Stabler's various publications and material in the Congressional Library to enable one to judge for 
himself whether the honors placed upon this inventor by the Patent Office, the Courts, by Congress, and by the farmer were earned.

It was at the time Mr. Hussey was residing in Baltimore that he turned his attention to the idea of a reaping machine and spent his leisure hours in working out his model. This satisfied him that the thing was practical, and he undertook an operating machine, which, although lightly made, was fully sufficient to test the great principle. At this time he had no knowledge whether any others had undertaken anything in this direction and there was nothing in his own mechanical occupation which would make him familiar wth the subject.

As the only other claimant for the honor of inventing the reaper was Cyrus $\mathrm{H}$. McCormick, reference is here made to a book entitled McCormick Claims Invention "Memorial of Robert McCormick," the father of Cyrus H. McCormick, Leander J. McCormick and William S. McCormick, published by the said Leander J. McCormick in 1885, pages 44 to the bottom of page 51 , also pages 58 to 61 inclusive, from which I extract:

"Now, while we have no disposition to question the merits of the so-called McCormick harvester and binder, which, without doubt, is a good machine,-though the judgment of foreigners as to its value is of no consequence,we do assert that C. $\mathrm{H}$. McCormick was not 
Denial by entitled to any of the honors showered upon Members of him as its inventor. To be more explicit, he McCormick

Family not only did not invent the said machine, nor mechanically assist in the combinations of the inventions of others which produced it, but he never invented or produced any essential elementary part in any reaping or harvesting machine from the first to last. These assertions are broad, but absolutely true. They stand squarely upon the records and the history and state of the art. C. H. McCormick, or any one for him, cannot deny them with proofs, therefore he is not entitled to recognition as the man who 'has done more to elevate agriculture than any man the world has produced,' because of his supposed inventions in this line; but on the contrary, that the development of Western agriculture has elevated him, and that he has more money, and received more honors, 'than any man the world has produced,' by appropriating the brains of others, and the credit due them as inventors, are propositions much more defensible."

* * * * * * * *

Their "But the man who is entitled to the most Affirmation credit, as inventor and pioneer in this business, of Bussey's is Obed Hussey, who, December 31st, 1833, Claim patented the machine (successfully operated in previous harvest, well known and in use since to this day), which combined all the main fea- 



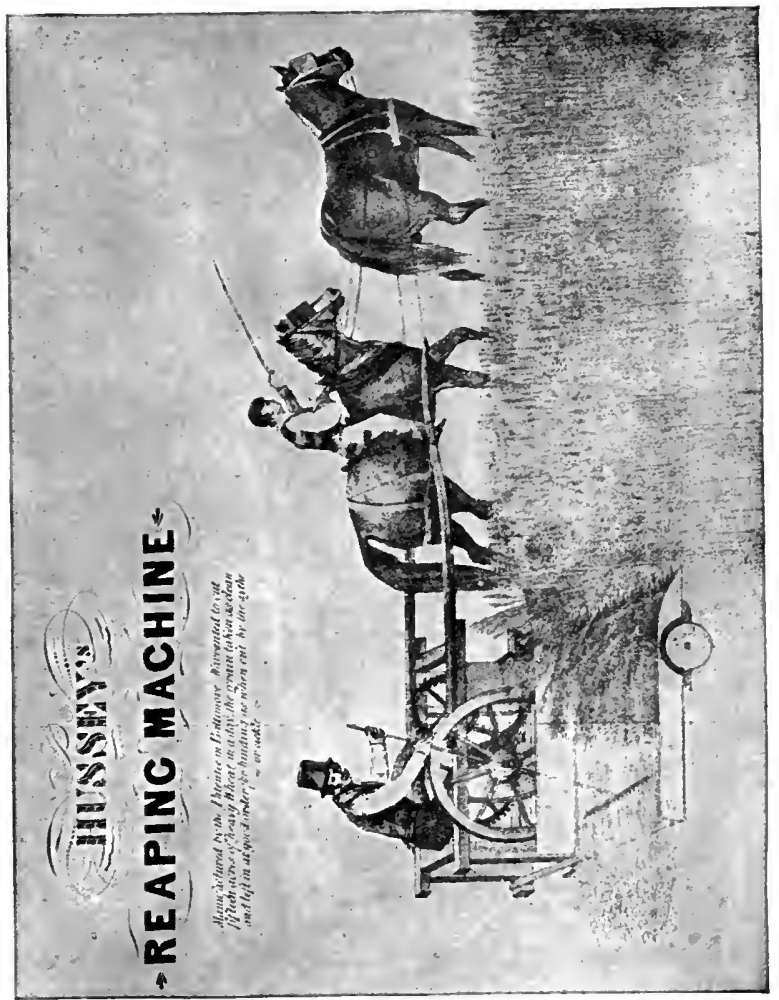

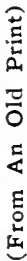


tures-except the reel, which was then an old device-of practical reapers down to the time, at least, when 'harvesters,' so-called, came into the field."

The following is also copies from "Memorial of Robert McCormick," published by Leander J. McCormick in 1885:

\section{TO THE CONGRESS OF THE UNITED STATES}

\section{"REMONSTRANCE"}

"Of the Citizens of New York against the renewal of Letters Patent granted to Cyrus $H$. McCormick, June 21, 1834, for improvements in the Reaping Machine.

"Among the early reaper inventors of this country, Mr. Obed Hussey, now of Baltimore, stood for many years deservedly the most prominent, and he has doubtless by his genius and indefatigable exertions (although in a modest way) contributed more to the advancement of this invention than any other man. $\mathrm{He}$ first tested his machine in 1833 , and took out a patent for it the 31 st of December of that year.

"He first constructed his machine with a reel to gather the grain up to the cutters, and The First Machine throw it upon the platform; but on trial, with his cutter, he thought it unnecessary and only an incumbrance, and, therefore, threw it aside and has never used it since. The main frame- 
work containing the gearing was suspended on two wheels about three feet four inches in diameter. The platform was attached to the rear of this frame, and extended out one side of it say six feet. The team was attached to the front end of the frame and traveled at the side of the standing grain as in Randall's machine. The cutting apparatus was pretty much the same as now used in Hussey's machine. The knife is constructed of steel plates, riveted to a flat bar of iron. These plates are three inches broad at the end where they are riveted to the bar, and four and a half inches long, projecting in front, and tapering nearly to a point, forming what is described as a saw with very coarse teeth, which are sharp on both edges. This cutter is supported on what he terms guards, which are attached to the front edge of the platform or cutter-bar (as termed by Hussey), one every three inches the whole width of the machine, projecting horizontally in front about six or eight inches. These guards have long slots through them horizontally through which the cutter vibrates, and thus form a support for the grain whilst it is cut, and protect the cutter from liability to injury from large stones and other obstructions. The cutter is attached by means of a pitman rod to a crank, which is put in motion by gearing connecting with one or both of the ground wheels 
as may be desired, according to circumstances, which gives to the cutter as the machine advances, a quick vibrating motion; and each point of the cutter vibrates from the centre of one guard, through the space between, to the centre of the next, thus cutting equally both ways. As the machine advances, the grain is readily cut, and the butts are carried along with the machine which causes the tops to fall back upon the platform without the aid of the reel. The grain to be cut was separated from that to be left standing by means of a point projecting in front of the cutter, in the form of a wedge, bearing the grain both inwards and outwards, with a board set edgewise upon it, sloping downwards, to a point in front. The grain was raked from the machine by a man riding upon it, in rear of the frame, at the side of the cutter, nearly in range with the guards, with his back towards the team, sometimes at the side and sometimes behind the platform. Soon after this date Mr. Hussey changed the construction of his machine somewhat, used one large ground wheel instead of two, placed the platform alongside the frame, and placed his raker on a seat by the side of the large ground wheel, facing the team, and raked the grain off in rear of the platform.

"This was for many years doubtless the The Most most practical reaping machine known, and, Practical 
with the improvements that have been made upon it, from time to time, it is now preferred to any other in many wheat growing sections of the country."

The fact and intensity of Mr. Hussey's struggles may, in part, be gathered from his letter to Edward Stabler, dated March 12, 1854:

"Baltimore, March 12, 1854.

"My Esteemed Friend, Edward Stabler :-

"I think the work goes bravely on. I am unable to express my estimation of thy disinterested efforts; I never before experienced anything of the kind; it seems entirely new to me to have any one go out of their way so much, to do so much for me. I am not so much surprised at the progress thee makes considering the man, as I am that any man could be found to do me such a service. I hope thee will not get weary; I am sure thee will not. I hope the Committee will not act so unjustly as to turn their backs on all cases because there is 'rascality' in some; because there is rascality in some cases, why should a just cause suffer? The facts in my case can be easily proved. I made no money during the existence of my patent, or I might say I made less than I would have made if I had held an under-clerk's position in the Patent Office; I would have been 
better off at the end of the 14 years if I had filled exactly such station as my foreman holds, and got his pay, and would not have had half the hard work, nor a hundredth part of the heart-aching. I never experienced half the fatigue in rowing after a whale in the Pacific Ocean (which I have often done) as I experienced year after year for eighteen years in the harvest field, I might say twenty years, for I worked as hard in England as I do at home, for in the harvest, wherever I am there is no rest for me. If I am guilty of no rascality why should I not be compensated for toiling to introduce an invention which I thought to be of so much advantage to the World. I know I was the first one who successfully accomplished the cutting of grain and grass by machinery. If others tried to do it before me it was not doing it; being the first who ever did it, why should I be obliged to suffer and toil most, and get the least by it? No man knows how much I have suffered in body and mind Mr. Hussey's Plea since 1833 , on account of this thing, the first year I operated it in Balto. Three years after I cut the first crop, I could not go to meeting for many weeks for want of a decent coat, while for economy I made my own coffee and eat, slept in my shop, until I had sold machines enough to be able to do better; there was no rascality in all that. My machines then cost 
me nearly all I got for them when counting moderate wages for my own labour. The Quaker who lent me the ninety dollars ten years afterward would not then (ten years before) trust me for iron, one who was not a Quaker did. There is one thing not generally understood; thou will remember the trial at Lloyd's, thou remembers also that I received the purse of 100 dollars; now what would the world suppose I would do? Why that I would do like the flour holders, keep the price up! But it is a fact and can be proved, that after it was announced to me that the verdict was in my favor I said to a gentleman now I will reduce my price 10 dollars, on each machine, and $I$ did it, from that hour and did not breathe my intention until after that decision was announced to me! Where is the man who has done the like under similar circumstances? There is no 'rascality' in that. Now I do not believe that there is a reaper in the country (which is good for anything) at so low a price as mine, and not one on which so little profit is made.

"I will inclose a pamphlet which I suppose thee has already seen-it may be useful.

"Thy friend,

(Signed) "OBED HUSSEY." 
Mr. William N. Whitely, an early inventor and manufacturer of harvesting machinery, who was for many years the king of the reaper business, and who fought the Hussey extension "tooth and nail," on January 8, 1897, wrote to the "Farm Implement News" upon the subject of McCormick's portrait on the silver certificates, then about to be issued, in which he refers also to Mr. Hussey, as follows:

“Editor 'Farm Implement News':

"Having been informed that the bureau of engraving and printing was preparing new $\$ 10$ silver certificates to be ornamented by the busts of Whitney, the inventor of the cotton gin, and C. H. McCormick, 'inventor of the reaper,' I From the Pen of a Hussey Opponent write you to say that it would manifestly be unjust to credit the invention of the reaper to any one man. Mr. McCormick does deserve great credit for his enterprise and business skill in the many years he was engaged in manufacturing harvesting machinery and we are pleased to honor his memory; yet so much has been done in bringing the reaper to its present state of perfection by the many thousands of inventors that our government would make a mistake in singling out Mr. McCormick from the many meritorious ones who have contributed so much to the reaper of the past and of the present day. We well understand that no 
effort has been spared for many years past in keeping C. $\mathrm{H}$. McCormick before the American people as the inventor of the reaper by his immediate relatives and friends, and we have no right to find fault with such a course upon their part; but when the great government of the United States of America proposes to certify by the above mentioned course to the correctness of the claims made for C. H. McCormick as the inventor of the reaper, to the disparagement of so many other worthy inventors and co-workers upon the reaper, then those who know better should raise their voices against such an attempted recognition for any one man, of whom the best that can be said is that he was only one of the many.

"From 1831 to 1834, and for several years thereafter, two persons, i. e., Obed Hussey and C. H. McCormick, were striving to produce a successful reaping machine for cutting grain and grass, as were many others, before and since. These two men were contemporaneously in the field, and no doubt they both labored faithfully to accomplish the desired result. The invention of Obed Hussey, the features of which were embraced in his first machine in 1832 and 1833, included all the principles of a practical reaper. It was a side draft or side cut machine; that is, the cutting apparatus extended out to one side, the animals drawing 
the machine moving along by the side of the grain or grass to be cut. It had two driving and supporting wheels, gearing extending rearward with a crank and pitman therefrom to reciprocate the cutters, which were scalloped or projecting blades from a bar and vibrated through slotted guard fingers which held the stalks to be cut. The cutting apparatus was hinged to the side of the frame of the machine to enable it to follow the surface of the ground over which the machine was passing. A platform was supported by an outer and inner wheel. The operator was seated upon the machine and raked the grain into sheaves from the platform as it was cut. Over sixty years have come and gone, yet all the essential features of the first Hussey machine and all Hussey machines made thereafter (which were large numbers) employed substantially these devices. The machine was successful the first time it was completed, and ever after were the Hussey machines successful in harvesting grain and grass. The fundamental principles of all harvesting machinery of the world to-day were furnished by Obed Hussey's invention and patent of 1833; and while very many and valuable improvements have been made thereon for harvesting grain and grass, for which credit should be given to the worthy inventors

The Reaper Itself Mr.

Hussey's Contribution 
who followed after Hussey, yet we must not ignore his valuable contribution, 'the reaper.'

"Cyrus H. McCormick's first patent was dated in 1834. This was known as a push machine with a straight cutter, the operator walking by the side of the machine and raking the grain from the platform. Other modifications in after years were made on this machine by Mr. McCormick; and it may be said that the inventive genius of Obed Hussey and the business tact and skill of C. H. McCormick produced and brought into practical use the first successful reaping machine of this or any other country.

"Whatever might have been embodied in the first McCormick machine or in his experiments or machines for the first fifteen years of

Whose his efforts, the reaper of the present day does Machine not disclose any principles contained in these Still Lives? early efforts of C. H. McCormick; but that cannot be said of Hussey. All reaping machines of the present day embody substantially all of the vital principles given by Obed Hussey in 1833 and at different periods thereafter. The Patent Office, as well as other sources of information, make good these statements.

"Passing, however, from the early history up to the present time, when the present mowing machines and grain binding machines are 
seen in operation, and taking into account the thousands of patents that have been issued to American inventors for various features that they have brought out, it would be but simple justice that all be recognized as contributors to the building up of such valuable and important pieces of machinery; and I cannot but repeat that it would be very unjust, unfair and unAmerican to single out one person, and that one Mr. McCormick, as a representative to be used by the government printing bureau, when it is so well known what he did and what he did not do in the invention of the reaper. It would be a false monument; it would only be respected by persons who are ignorant of the facts.

"If this should succeed, it would not be the first time, as likely it will not be the last time, in the history of mankind where those who did the work were soon forgotten and those who were more fortunate in being held up and prominently kept before the public by their friends or powerful allies received unjustly the credit."

It will be seen from the foregoing extracts that Mr. Hussey's machines went early into the field in such quantities as he and other little Early Ventures in Manufacture manufacturers throughout the country, some of whom ignored the exclusive rights granted him, could put them out. They were simple, 
and a few castings were all that was necessary, except lumber, which was plenty in the forests of the East and in the groves of the West, to enable a country wagon maker and blacksmith to put machines into the field. Many of the earlier inventors, who began the manufacture of reapers of their own invention, followed that course and castings were sometimes brought from great distances. Mr. Hussey applied for an extension of his 1833 patent, but, not know-

An ing the exact requirements, his application was Unfortunate offered too late, sixty days before the expiraDelay tion of the patent being the time allotted. Knowing, we presume, but little about law, and still less about "the rules and regulations of the Patent Office"-for all his time, and constant labor with his own hands, were required in the workshop to earn a bare support,--but being very desirous to obtain an extension of his Patent before it should expire, and also having some personal acquaintance with Commissioner Ellsworth, Hussey's first application was made to him in 1845 , a short time previous to his going out of office; certainly not less than twelve months before the expiration. This is proved by the annexed letter:

"Dear Sir :- "La Fayette, Ia., July 3, 1854.

"Your letter of some weeks since, referring to a conversation I had with you while I was 
Commissioner of Patents, relative to the extention of your patent for a Reaper, would have been answered earlier, but for absence and extreme pressure of business.

"If my recollection will aid you, I most cheerfully state, that before your patent expired, you consulted me as to the extension of the same. I replied that it was better to postpone an application until near the time the patent would run out, for the Office must estimate the profits of the invention during the whole term; and you accordingly postponed it. I regret you postponed it too long. The publication of thirty days before the patent expired, was a rule as published by myself. If you have lost your opportunity for relief through (the) Patent Office, you must of course go to Congress. I have always regarded your improvement as valuable, and that the country is greatly indebted to your persevering efforts, notwithstanding the obstacles presented.

\section{"Yours respectfully, "HENRY L. ELLSWORTH.}

"Mr. Obed Hussey, Balto., Md."

Hussey acted on this official advice, and did "postpone an application until near the time the patent would run out"-literally so, for he was not advised of even the "thirty days' rule." 
Why Mr. Hussey's Application Was Late

When he again applied, and not "until near the time the patent would run out," Edmund Burke was Commissioner of Patents. He states in a letter to Senators Douglas and Shields, under date March 4th, 1850, as follows:

"In relation to the patent of Hussey, if my memory serves me, his patent expired some time within the latter part of December, 1847. During that month, and within some ten or twelve days before the expiration of his patent, he applied to me as Commissioner of Patents for an extension. I informed him, that inasmuch as the act of Congress prescribed the mode in which patents should be extended; required a reasonable notice to be given to the public in sundry newspapers, published in those parts of the country most interested against such extension; and as the board had decided that 'reasonable' notice should be a publication of the application for extension three weeks prior to the day appointed for the hearing, there was not time to give the required notice in his case; and I advised Mr. Hussey not to make his application, and thus lose the fee of $\$ 40$ required in such cases, as he inevitably would, without the least prospect of succeeding in his application-but to petition Congress for an extension, which body had the power to grant it." 


\section{"Washington, 5th Sept., 1854.}

"Obed Hussey, Esq., Baltimore:-

"My Dear Sir: I have recently learned, with surprise and indignation, that certain speculating harpies who fill their coffers with the products of other men's brains, and who, in your case, seek to 'reap where they sow not' are basely and unjustly endeavoring to prevent a renewal of your patent for your 'Reaping and Mowing Machine,' upon the ground [among others] that you and your agents have neglected to press your Claim properly before Congress.

"I have been your Agent from the time the claim was first presented to Congress, and know that the Charge is entirely unfounded.

"The facts according to the best of my recollection and belief, are as follows: Your Claim for a renewal was presented to Congress at the very first Session, after you ascertained that your application to the Commissioner could not be acted upon under the rules of the Patent Office. Every paper and proof necessary to establish your right to a renewal of your patent, under the existing laws, was procured, and promptly placed with your memorial, before Congress. No further proof was required by the Committee on Patents, in the Senate, and your right to a renewal was fully 
An Able established by an able and unanswerable reand port of that Committee, accompanied by a bill Unanswerable

Report for a renewal. This report and bill were printed by order of the Senate, and were noticed as a part of the proceedings of Congress, by the press throughout the United States, and every body thus notified of your application.

"From that period to the present time, I do not think there has been a single Congress at which all proper efforts were not made to obtain the action of that Body. Members were not annoyed with indecent importunity; nor were any powerful combinations of interested individuals resorted to, to force your Claim upon the consideration of Congress. This was Mr.Hussey's not in accordance with your taste, or your Methods means. I well remember, however, that you frequently visited this City on that business; and that at almost every session, you either brought or sent to me, to be laid before Congress, some new evidence of the triumph of your great invention. These documents were faithfully laid before that body, or sent to the senators from Maryland for that purpose. On one occasion, as your agent, I addressed a somewhat extended communication to the Senators from Maryland, attempting to show the vast importance of your invention to the Agricultural interests of the United States, and the strong claims you had to a renewal of your 
patent, and requested them as the Representatives of your State in the Senate, to give their attention and influence to accomplish that end.

"At a subsequent Session, this request was repeated, to one or both of the Senators from that State.

"I can also state with certainty that hardly a Session of Congress has passed since your memorial was first presented, at which prominent and Scientific Agriculturalists, in different parts of the Country, who were acquainted with the merits of your invention, have not used their influence with Members of Congress to obtain a renewal of your patent. Any pretense, therefore, that your Claim has not been duly presented, notified to the public, and urged with all proper care and diligence upon the attention of Congress, I repeat is totally unfounded.

"It will be a stain upon the justice of the Country, if one whom truth and time must rank among its greatest Benefactors, shall be stricken down and permitted to die in indigence by the interested and unworthy efforts thus made to defeat you.

"You are at liberty to use this statement in any manner you may desire.

$$
\begin{aligned}
& \text { "Very truly and respectfully, } \\
& \text { "Your Ob't Ser'vt, } \\
& \text { "CHA'S E. SHERMAN." }
\end{aligned}
$$


Although not coming in the natural order of events, I quote from an enclosure found in a letter written to Hon. H. May, evidently a member of Congress. Mr. Hussey having failed to apply for an extension of his 1833 patent early enough, a bill was introduced in Congress with an extension in view. In some correspondence between $\mathrm{Mr}$. Hussey and the Hon. H. May an enclosure is found reading as follows :

"During the examination of my case in the Committee-room on the 21 st inst. you asked me a question, and accompanied it with a remark to the effect "Why could I not raise a company in Baltimore with sufficient capital and make as many machines as Howard \& Co. and compete with them on equal ground? The Mr.Hussey's excitement of the occasion disqualified me for Defense giving a full reply to your question and remarks. I was at the time so impressed with the injustice and the great hardship of being compelled to compete with the world for what of right belonged to myself exclusively that I had not the words to express my feelings. Could any gentleman look back twenty-one years and see me combating the prejudices of the farmers, and exerting the most intense labor of body and mind, and continuing to do so from year to year, at the very door of pov- 
erty, and also look back on those New York parties through the same period, accumulating wealth by the usual course of business, and perhaps watching my progress, and waiting for the proper moment to step in with their money power and grasp the lion's share of the prize which justly belongs to myself. If they could look back on the circumstances and comprehend the case in all its reality and truth I should have no fear of a just decision by the Committee in the House of Representatives. The Government which can tolerate and uphold such a state of things would appear to me to be a hard Government.

"The end and design of the Patent Laws was to reward the inventor for a valuable invention by giving him the exclusive right to make and vend the article which he had invented and fourteen years was deemed a sufficient time in which to secure that reward. The telegraph was perfect on its first trial. It required no improvement. On the contrary, half the wire was dispensed with. The Government was at the cost of trying the experiment and has since heaped wealth on the inventor. My fourteen years were required in perfecting my invention without any return for time and labor. (The finishing touch to his cutting ap- 
paratus is, no doubt here referred to, and shown in his patent of 1847.)

"Public opinion on the subject of valuable inventions is liberal until an obscure individual appears in the community claiming the reward for a valuable invention; the disposition then seems to be to let him shrink into a corner. The world has got the advantage of his labors and has no further use for him; every unreasonable man in the community will at once claim an equal right with the inventor of the device and one not content to urge their claims Mr. Hussey's by misrepresentation but must heap abuses on the poor inventor who they have in a great measure pushed out of their way. The idea that a wise Government, of an enlightened country, can not only look on and suffer such injustice but will actually encourage it by disregarding the prayers of the poor inventor is a mystery to those who build their hopes on the dogma that 'Truth is mighty and will prevail.' I hope the Committee will not pass lightly over my case but duly consider, as I believe they will, to whom the advantages of this invention belongs, whether to me or to the parties in New York. My chief aim in addressing this to you is to endeavor to draw a parallel between myself and the parties in New York, and thereby secure your good opinion in my favor." 
Edward Stabler, on January 11, 1854, wrote to Hon. Henry May as follows:

"As requested I have examined the peti- Farmers tions of the 450 farmers who advocate the extension of Hussey's patent and from a personal acquaintance or by character with much larger Using Hussey Reaper portion in Delaware, Maryland, Virginia, and North Carolina, and on reliable information of those from New York-234 in number-I am satisfied that they are wheat-growers to an amount of not less than from four to 500,000 bushels annually. * * * They used Hussey's reaper, and some of them three and four, or more of these great labor-saving implements."

Mr. Edward Stabler writes to Henry May, under date March 19, 1854 :

"The most that I fear is that Hussey's interests (which all appear willing to admit is a meritorious case) may suffer in the contests that I am satisfied will take place with regard to Moore \& Haskell's and McCormick's extensions. I should be greatly pleased, and have stronger hopes if Hussey's case could be acted on promptly and before that contest begins. "On the ground of its having been so long and so favorably reported on, by the Senate's Committee in '48-six years next May, possibly it could be called up at an earlier date,the sooner the better, to avoid competition 
from interested parties, and which I certainly anticipate if long delayed in either House of Congress. Honestly believing the cause just and right, for no fee, however large, could tempt me to advocate what I thought unjust or wrong, I shall persevere as long as there is ground for hope. If we fail I shall have pleasing reflections, doing unto others as you would that they under similar circumstances should do unto you."

Mr. Edward Stabler, on February 5, 1854, wrote to J. A. Pierce, member of one of the Committees, a letter from which the following is extracted:

Mr.Hussey's

Character and Service

"I will, however, preface my remarks by saying that I have no connection whatever with his business operations nor pecuniary interest in his affairs, but being well acquainted with him I am free to say, that I have known no man on whose word I have placed more implicit reliance, no one more honestly entitled to what he asks for.

"He has faithfully devoted the prime of his life, and no small portion of it either, in the invention and the perfecting of the reaping and mowing machine; and his untiring perseverance has certainly been crowned with success so far as to confer a signal and lasting benefit on his country; but unfortunately he 
has derived no corresponding advantage for himself, and from no fault on his part.

"While C. H. McCormick has literally fattened on the agricultural public by the sale of his inferior and cheaply made machines-for such I do consider them, both from my own observations and the report to me by those who have been induced to purchase themHussey has been pirated on from all quarters, and others reaping the reward of his labors. And I perceive by the papers on file, and accompanying the printed report (No. 16) that this same C. H. McCormick has actually petitioned against the renewal of Hussey's patent. It is really a very hard case, that a poor man and one of the most deserving in the community in every sense of the term, should thus fail of a just reward when he has done so much for the benefit of others. *** Believing as I do that the extension is no more than sheer justice to Obed Hussey,-quite equal in merit to any that has been granted,-as one of the most meritorious in the language of the Committee, I do most earnestly solicit thy kind aid and influence to get it through the Senate. * * * He was then (and still is) a comparatively poor man; without the means from his limited sales to extend his business in a profitable manner or to protect his known and acknowledged rights from the depredations of

Opinion of an Able Mechanic 
others. His shops-and I speak from personal knowledge-are for the most part dilapidated sheds-too confined and cramped up to do any part of his work to the best advantage, and from a personal knowledge speaking as a practical machinist of some 25 years experience, I do know that his profits are far less than some other machine makers-not the half of what is usually supposed.

"Take, for example, the machines as usually made by Obed Hussey and C. H. McCormickfor I am familiar with both; owing to the quality of the work, costs of material and arrangement of the mechanism, two of McCormick's

The Two Machines Compared

can be made by him for little or no more than the cost to Hussey of one of his. Such, too, is the statement on oath of competent men employed by both manufacturers. McCormick's foreman and clerk have sworn (see petition from New York against his extension) that his machines are made for some $\$ 35$ to $\$ 40$ each. Any man who will undertake to make and sell Hussey machines as he makes them for much less than double this sum, will soon beg his bread if he depends on his profits to buy it, unless he cheats his hands out of their part."

A postscript is added, which reads :

"I should have made no allusion to $C$. $H$. McCormick or to his machines, had he not 
volunteered by petition to injure his rival-in my opinion a most worthy, reliable and deserving man-and I would add that in my estimation the two machines differ just about as widely as the two men."

We may assume that Mr. Hussey must have begun on his large machine late in 1832, or early in 1833, at latest. During the early part of the harvest of 1833 he was in the field. "The machine was started," Stabler tells us, "but owing to some part giving way, or some slight defect not apparent until then, it at first failed to work satisfactorily. One burly fellow present picked up a reaping cradle and, swinging it with an air of great exultation, exclaimed, "This is the machine to cut the wheat!' " Another account charges the breakage to a fractious team.

"After the jeers and merriment of the crowd had somewhat subsided, the inventor remedied Mr. Hussey's Triumph the defect, and assisted by the laborers present - the horses having been removed-pulled the machine to the top of an adjacent hill; when, alone, he drew the machine down the hill and through the standing grain, when it cut every head clean in its track. The same machine was directly afterwards exhibited before the Hamilton County Agricultural Society near Carthage, on the 2nd day of July, 1833." 
The secretary of the Society wrote an exceedingly favorable report. The group of spectators present at this trial drew up a testimonial that was very favorable indeed. On July 2,1833 , then, we are warranted in saying, the problem that had so long exercised the minds of inventors was solved.

Fortunately Mr. Hussey was not as easily discouraged as many. He, no doubt, felt chagrined that his machine had broken down, but had the pluck then and there to make an effort to close the hooting mouths, and fully succeeded. In 1834 other machines were put out. We learn from the Genesee Farmer, dated December 6, 1834, that Mr. Hussey, the inventor of a machine for harvesting wheat, had left in the village one of his machines for the purpose of giving the farmers an opportunity to test its value. During the harvest of 1834 it was operated in the presence of hundreds of

The Hussey farmers with most satisfactory results. We Reaper in the Field next find Mr. Hussey at Palmyra, Mo., on July 6,1835 , with two of his machines, at the farm of his old friend, Edwin G. Pratt. The machine "excited much attention, and its performance was highly satisfactory." The results of the trials were published in the "Missouri Courrier" in August or September of 1835. The machines were sold for $\$ 150$ each. A Mr. Muldrow bought another kind of machine, 



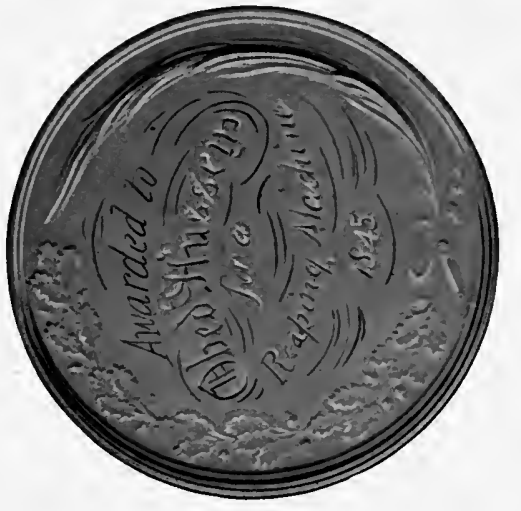

ڤ

岳

훈

悹

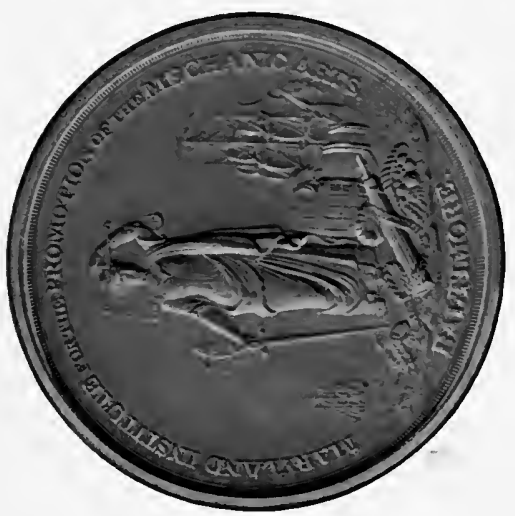

点

용

矢 
however, in which the cutting was done by a "whirling wheel" and paid $\$ 500$ for it. In 1836 Mr. Hussey was in Maryland, at the written solicitation of the Board of Trustees of the Maryland Agricultural Society. The fame of his reaping machines in the state of New York, and the far West, had spread, "though with something like a snail's pace," as new things did two-thirds of a century ago. The machine was operated at Oxford, Talbot County, on the 1st of July, in the presence of the Board and a considerable number of other gentlemen. Its performance was perfect, as it cut every spear of grain, collected it in bunches of the proper Public Tests size for sheaves and laid it straight and even for the binder. On the 12th of July a public exhibition was made at Easton, under the direction of the Board; several hundred persons, principally farmers, being present. This same machine was sold to $\mathrm{Mr}$. Tench Tilghman, for whom it cut 180 acres of wheat, oats and barley during that season. The report of the Board of Trustees of the Maryland Agricultural Society stated that "three mules of medium size worked in it constantly with as much ease as in a drag harrow. They moved with equal facility in a walk or trot." In 1837 the machines were sold in various parts of the country. One at Hornewood, Md., one at West River, and several others throughout the state. One of 
the machines sold in 1838 to the St. George's and Appoquinomick Ag. Society cut several hundred acres of grain, up to 1845 , and was then in good repair. In all this time the cost for repairs was only $1 \mathrm{I} / 4 \mathrm{c}$ per acre. The popularity of the machine became so pronounced that other inventors were given courage, and those who before had failed were prompted to pick up their work where they had dropped it or begin on newer lines.

In 1843 we find that Hussey's machine was in a field-contest with one brought in by Cyrus H. McCormick of Rockbridge County, Va. We say brought in, because the claim that it was in fact invented and made by Robert McCormick seems to be quite well founded. (Memorial of Robert McCormick.) The contest took place on the farm of a Mr. Hutchinson, about four miles above the city of Richmond. Mr. Hussey had, for a number of years, been building two sizes of machines, and at the first day's

A Bussey. trial was obliged to use a small one because McCormick Contest his only large machine within reach was elsewhere occupied. The majority of the selfappointed committee of bystanders reported in favor of McCormick's machine, but Mr. Roane, one of them, who signed very reluctantly, later bought a Hussey machine. A few days after, at Tree Hill, Mr. Hussey was present with his large machine. 
In the "American Farmer" was soon after published a letter from Mr. Roane, dated January 23,1844 , to $\mathrm{Mr}$. Hussey, in which, among other things, he says:

"Averse as I am to having my name in print on this, or any other occasion, I cannot with propriety decline a response to your inquiry. I had never seen or formed an idea of a reaping machine until I went to Hutchinson's. I was surprised and delighted with the performance of each of them, and fully resolved to own one of them by the next harvest, but their performance that day left me in a state of doubt which I should select. The report spoke in terms of high praise of each machine, and I consented to its award, that on the whole Mr. McCormick's was preferable, merely because being the cheapest, and requiring but two horses, it would best suit the majority of our farmers, who make small crops of wheat on weak land, for I doubted its capacity in heavy grain. After this report was made I heard your complaint that you did not have a fair trial, because being unable to bring into the field your large improved reaper, which was up the river, you were compelled to comply with your engagement for the day, with a small and inferior machine, drawn by an indifferent and Mr. Roane's Letter untutored team. Mr. Hutchinson's wheat was badly rusted, and therefore light. I had ready 
for the scythe a low ground field of heavy and well matured grain; partly to expedite my harvest work, and partly to renew the trial, that I might solve my doubts as to the merits of these machines, I succeeded in engaging them to be at Tree Hill on a named day. They both came agreeable to appointment, Mr. McCormick bringing the machine he used at Hutchinson's, and you bringing the one you could not on that occasion bring down the river. The day was fine, and both machines did their best, and had a very fair trial. My doubts were fully removed, and my mind convinced that in the heavy wheat we raise on our river low grounds, rich bottoms, etc. your machine is superior to Mr. McCormick's of which I still think highly. I accordingly ordered one of yours to be made for the approaching harvest.

"I wish you all possible success in cutting hemp in the 'Great West.' It must be very desirable to cut that valuable plant instead of pulling it up by the roots, and I cannot doubt that your reaper has ample power for the purpose." (Records of U. S. Patent Office.)

Mr. Hussey

No one will claim that Mr. Hussey was Not a what may be termed a good business man; Business like most inventors, his mind was on what he Man sought to accomplish rather than on the hoard- 
ing of weath. I have already quoted from correspondence that passed between him and his friends, when attempting to get his 1833 patent extended.

An early manufacturer, well known to $\mathrm{Mr}$. Hussey and who paid royalties under Mr. Hussey's patents, writes:

"Mr. Hussey's early machines were made by Jarvis Reynolds of Cincinnati, Ohio," we are informed by Mr. William $\mathrm{N}$. Whitely, who early became familiar with many of the facts, he having opposed Hussey's extension application, "in a shop on the river front, beginning in 1831 or '32. After making that operated in 1833 he built several others during two or three years or more. Some of the early ones were taken to Glendale, Ohio, to the farm of Algernon Foster."

"The first machine taken there had a reel on it, but after using it a short time the reel was laid aside. On the same machine was an extra platform, attached to the rear, so that the raker could deliver the grain to one side. The machines were intended for both reaping and mowing." Mr. Whitely states that he saw two of the machines still on Mr. Foster's farm in 1860 , that had been there since, probably, 1835 .

"The machines were at first bought by farmers who did cutting for the neighbors and under the circumstances were anxious to pros- 
trate as many acres of grain per day as possible; in order to accomplish this, they applied four horses and moved on a 'jog trot.' So moving the reel was found of little service because the rapidly moving machine caused the severed straws to fall backward on the platform so that the raker had little to do but to remove it, except where it was particularly badly lodged; in such cases he manipulated his rake as it is now used on all reelless reaping machines."

After building the machines for Algernon Foster, Mr. Hussey undertook the manufacture of two or more machines for the harvest of 1835. From a letter received from John Lane, we quote:

" 'Old Judge Foster' was a well known jurist and judge of court in Hamilton County, Ohio, having his country home (a farm) $31 / 2$ miles near due east from my father's place of business, and it was he who introduced Obed Hussey to John Lane as being a mechanic who could and would make for him the reaper he A Contract was at that time seeking to have made in Cincinnati. Also it was agreed between said Hussey and Foster that when said reaper had been made and tested to their satisfaction in the standing grains, his sons, Algernon and brother (whose name I do not remember) would pay 
all costs of making said reaper and put the same in use to best of their ability."

I quote from the book entitled "Valley of the Upper Wabash, Indiana," published by Henry Ellsworth in 1838:

"Another material reduction of the expense attending the cultivation of hay and other crops will be found in the use of some of the mowing and reaping machines recently invented.

"A machine of this description, invented by Mr. Obed Hussey, of Cambridge, Maryland, Editorial Comment has of late excited general admiration, from the neatness and rapidity of its execution, and the great amount of labor which its use will save. Its introduction on large farms, of the description we have mentioned, will undoubtedly be followed by remarkable results. These machines, when in good order (and they seldom need repair), can cut from twelve to fifteen acres of grass, and from fifteen to twenty acres of wheat, daily.

"The following letter from John Stonebraker, Esq., of Hagerstown, Maryland, will exhibit his experience in the use of this machine.

"He was induced (as the writer knows from personal communication with him on the subject) to try it from the representations of 
others, and with many misgivings as to the result. That trial, however, has satisfied him and with him, many of his neighbors, of the great utility of the machine.

"The letter is as follows:

\section{“'Hagerstown, August 15, 1837.}

" 'Dear Sir: Will you please give this a place in your paper, for the benefit of wheat growers. As the subject is of public interest, it is hoped that other papers will circulate it through the grain growing districts of the country.

"I procured a reaping machine this summer of Mr. Hussey, the inventor, which I have used through my wheat harvest. It was in constant use every day, and performed its work to my satisfaction, and far better than I had any expectation of when I first engaged it of $\mathrm{Mr}$. Hussey. When the ground is clear of rocks,

A Hussey loose stones, stumps, etc., and the grain stands Testimonial well, it cuts it perfectly clear, taking every head; and, if well managed, scatters none, but leaves it in neat heaps ready for binding. When the grain is flat down, the machine will of course pass over it; but if it be leaning, or tangled only, it is cut nearly as well as if standing, excepting when it leans from the machine, and then if the horses are put in a trot it will be very well cut. But in cutting such grain 
much depends on the expertness of the hand who pushes off the grain, in making clean work and good sheaves. I found the machine capable of going through anything growing on my wheat land, such as weeds and grass, no matter how thick.

" 'After my harvest was over, I cut my seed timothy with the same neatness and ease that I did my grain. As respects the durability of the machine, I can say this much for my machine, that not the least thing has given out yet; it appears as strong as a cart, and but little liable to get out of order, if well used. I was advised by Mr. Hussey of the necessity of keeping some of the parts well greased; this I have punctually attended to, and no perceptible wear yet appears, beyond the ordinary wear of any other machinery.

" 'It is immaterial to the machine whether the speed be a walk, or trot; although a walk will make the most perfect work. My speed was a common walk, but a trot is sometimes necessary to counteract the effect of a strong wind when blowing from behind, in order to incline the grain backwards, on to the platform, to make good bundles. A quick walk is required to make good work in very short and scattering grain. The machine performs well, up or down hill, provided the surface be not too broken. By its compactness and ease of

Durability of the Machine 
management, rocks, and stumps too high to be cut over, can be easily avoided. Although a rough surface is very objectionable, yet I have cut over very rocky ground with no material difficulty. I can say one thing which to some may appear incredible, but it is not the less true; the cutters of my machine have not been sharpened since I have had it; nor have I yet seen any appearance of a need of it in the quality of its work. How many harvests a machine would cut without sharpening is hard to say. I propose sharpening mine once a year only. I have used two horses at a time in the machine, and sometimes changed at noon; they worked it with ease, the draught being light. I took no account of what I cut in any one day, with this exception: in less than half a day I cut six acres, and was often detained for want of the requisite number of binders, by which much time was lost. My machine being something narrower than those generally made by Mr. Hussey, I could cut but about one acre in going two miles; this, at the moderate gait of two and a half miles per hour, would amount to twelve and a half acres in ten hours; and at four miles per hour, a speed at which the work is done in fine style, the amount would be twenty acres in ten hours. I should judge my quantity per day to range between ten and fifteen acres, yet I am decided in the opinion that 
I can cut twenty acres in a day, of good grain, on good ground, by the usual diligence of harvest hands, with a little increase of my usual speed, and a change of horses. Two hands are required to work the machine, a man to push off the grain and a boy to drive, besides a number of binders, proportioned to the quantity cut. As the machine can be drawn equally fast in heavy or light grain, the number of binders is necessarily increased in heavy grain, except an additional speed be given in light grain. Under every circumstance, the number of binders will vary from four to ten; and, when the usual care is practiced by the binders, there will be much less waste than in any other method of cutting.

"I speak with more confidence of the merits and capacity of Mr. Hussey's reaping machine, from the circumstance of having pushed the grain off myself for several days, in order to make myself practically and thoroughly acquainted with it, before putting it into the hands of my laboring men. The land in this country being rather rocky and uneven, it is hard to say what may be the ultimate advantage of these machines to our farmers; but from what little experience I have had, I am resolved not to be without one or two of them. A LaborSaving Machine I can therefore recommend the machine with 
confidence, especially to those who have a large proportion of smooth ground in cultivation. It is undoubtedly a labor saving machine, and worthy of their attention.

\section{'JOHN STONEBRAKER.}

'Mr. Bell, Editor of the Torch Light.'

"To this testimonial from one of the best and most practical farmers in Maryland could be added many more, should they be needed. Farther improvements on the part of the inventor, during the past year, have much increased the power of the machine; and its adoption, as a valuable agricultural implement, is becoming very general.

Other

"One of these machines is now in the posTestimonials session of the writer, which arrived too late for use during the harvest of the present season. From one or two trials, however, and those under the disadvantageous circumstances of arranging a new machine, and the forced selection of a spot little suited for experiment, no doubt remains of the result.

"We add a letter to the inventor from Colonel Tilghmann, who also resides near Hagerstown, Maryland.

“'September 15, 1837.

"'Sir: Your wheat cutting machine was used by me in securing my clover seed. With one man, three boys, and two horses, we cut 
about twelve acres per day. The operation was in every respect complete. The clover was well cut, and deposited in proper sized heaps, and no raking required, further than to remove the heaps of cut clover from the track of the machine. The whole operation was easily performed by the hands and the horses.

" 'In the operation of cutting wheat, I followed the machine for two hours in the field of Mr. John Stonebraker, during the late wheat harvest, and can vouch for the operation in securing his wheat in the manner described in his publication. The late improvements made by you in your machine have added greatly to the beauty and facility of its operation.

'Yours respectfully,

'F. TILGHMANN.'

'Mr. Hussey.'

"We add the following notice of this machine, from Messrs. S. and E. P. Le Compte, enterprising farmers, of Cambridge, Maryland, as follows :

" 'Cambridge, July 3, 1838.

" 'We have employed Mr. Obed Hussey's wheat cutting machine to cut for us about thirty-four acres; the greater part of which was very heavy. We were remarkably well pleased with the performance of said machine, and are of opinion that, with proper manage- 
ment and attention, it will cut twenty acres per day, and save it much better than any other mode of cutting we have ever tried. “'S. \& E. P. LE COMPTE.'

"To which is appended the following postscript :

" 'I have been a practical farmer forty years; and am well satisfied, that, on a large farm, this machine will save wheat enough, beyond the scythe and hooks, to pay all the expense of cutting and binding.

"'SAMUEL LE COMPTE.'"

I next quoted again from the "Valley of the Upper Wabash, Indiana:"

\section{HUSSEY'S GRAIN CUTTER}

"Report of the Board of Trustees of 'The Maryland Agricultural Society,' for the Eastern Shore, on the machine for harvesting small grain, invented by Mr. Obed Hussey, of Cincinnati, Ohio.

Invitation of Agricultural Board

"The favorable accounts of the operation of this implement in several of the Western States, induced the board to invite Mr. Hussey to bring it to Maryland, and submit it to their inspection. It was accordingly exhibited in Oxford, Talbot county, on the first of July, in presence of the board, and a considerable num- 



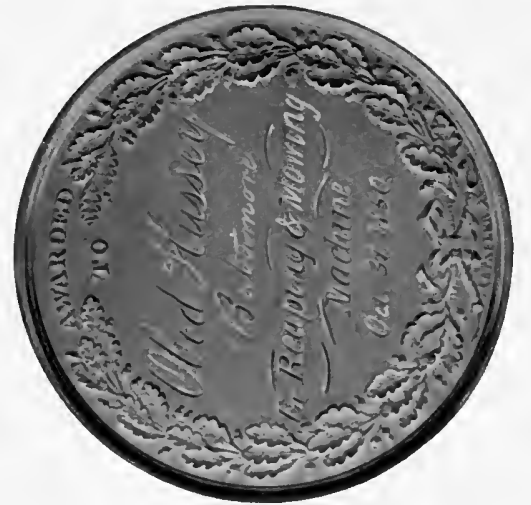

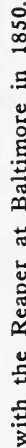

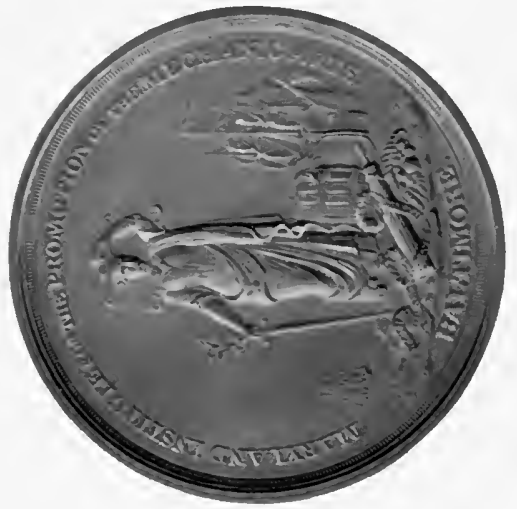

点

点

品

茫

을

5

7

롱

$\stackrel{2}{2}$ 
ber of other gentlemen. Its performance may justly be denominated perfect, as it cuts every spear of grain, collects it in bunches of the proper size for sheaves, and lays it straight and even for the binders. On the 12th of July a public exhibition was made at Easton, under the direction of the board; several hundred persons, principally farmers, assembled to witness it, and expressed themselves highly satisfied with the result. At the Trappe, where it was shown by the inventor on the following Saturday, an equal degree of approbation was evinced. It was afterwards used on the farm of Mr. Tench Tilghman, where 180 acres of wheat, oats, and barley were cut with it. Three mules of medium size worked in it constantly, with as much ease as in a drag harrow. They moved with equal facility in a walk or a trot. A concise description of this simple implement will show that it is admirably adapted to the important purpose for which it was invented. Resting on two wheels, which are permanently attached to the machine, and impart the motion to the whole, the main body of the machine is drawn by the horses along the outer edge of the standing grain. As the horses travel outside of the grain, it is neither knocked down or tangled in the slightest degree. Behind the wheels is a platform (supported by a roller or wheel), 
which projects beyond the side of the machine five feet into the grain. On the front of the edge projecting part of the platform is the cutter. This is composed of twenty-one teeth, reBow the sembling large lancet blades, which are placed Reaper side by side, and firmly riveted to a rod of iron. Worked A lateral motion is imparted to it by a crank, causing it to vibrate between two rows of iron spikes, which point forward. As the machine advances, the grain is cut and falls backwards on the platform, where it collects in a pile. A man is placed on the part of the platform directly behind the horses, and with a rake of peculiar constraction pushes off the grain in separate bunches, each bunch making a sheaf. It may appear to some that the grain will accumulate too rapidly for this man to perform his duty. But, upon considering the difference between the space occupied by the grain when standing, and when lying in a pile after it is cut, it will be evident that the raker has ample time to push off the bunches even in the thickest grain. In thin grain he has to wait until sufficient has collected to form a sheaf.

"The machine is driven around the grain, which may be sown either on a smooth surface or on corn ridges. For the first round a way may be cleared with a cradle; but this is deemed unnecessary, for the grain, when driven over, is left in an inclined position, and 
by cutting it in the opposite direction as much of it is saved as with a cradle. Fourteen acres in corn lands were cut between $10 \mathrm{~A}$. M. and $71 / 2$ P. M. The hands had never worked with the machine before, nor was it a trial day's work; for, owing to the shortness of the straw, the machine was not allowed to cut when passing over the ridges from one side of the ground to the other, and this time was consequently lost. From the principle on which the cutting is performed, a keen edge to the cutter is by no means essential. The toughest weeds, an occasional corn stalk, or a stick of the thickness of a man's little finger, have been frequently cut without at all affecting its operation; it can be sharpened, however, in a few minutes with a file. The width of the swath may be increased by having the cutter made longer, and the same machine will cut a stubble of several different heights.

"There is ample room to make the different parts of any size, though the strength of every part has been fully tested. The machine has been often choked by oyster-shells getting into the cutter, in attempting to cut too low a stubble. The motion of the machinery being checked, the main wheels slide on the ground; the strain on every part being equal to the power exerted by the horses. It can be managed by any intelligent, careful negro. We

Mr. Bussey Awarded Silver Caps 
deem it a simple, strong, and effective machine, and take much pleasure in awarding unanimously the meritorious inventor of it a handsome pair of silver cups.

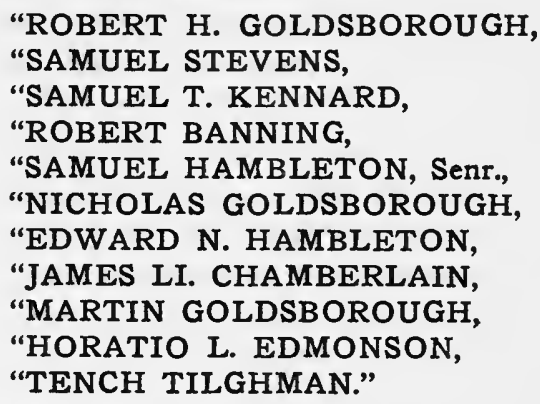

Mr. Lane goes on to say that one of the machines was taken to La Porte, Indiana, and there put to work. Another was sent to Illinois.

"The turning and fitting for these machines was done at the mill of Henry Rogers, about 500 yards away from the little shop. In the following copy of a recent affidavit sent us, date not given, these last matters are sufficiently substantiated."

Mr. Lane continues:

The True Inventor

"Who invented the Reaper? The full, honest answer is that Obed Hussey invented the Reaper.

"Between April and July, 1835, John Lane and Henry Rogers (with Isaac and Clark Lane 
assisting in the work) at their respective places of business one mile north of Mt. Healthy, Hamilton County, Ohio, made to order of Obed Hussey one Reaping machine for S. F. and Algernon Foster, then of the same County and State. Said Reaper was made to conform to or with drawings and patterns made and furnished by the said Obed Hussey, who also superintended the work of making the machine, and witnessed its trial in the field near the middle of June, 1835, in presence of many farmers, mechanics and others near by where the same was made; and when and where it was delivered to the Messrs. Foster's, who took this same reaper to La Porte County, Indiana, for the reaping season of the same year.

"For the iron and steel work done as aforesaid books in my possession show that fiftythree and $69 / 100$ dollars was paid by Messrs. Fosters, July 6th, 1835, to John Lane and by him receipted for in full, etc., etc.

"The cutting device we then made for this machine evidently was the invention of Obed Hussey; and it was as near exactly the same in all material parts to the cutting device now universally in use, as the hand made sickle could then or now be made. The sections of sickle were forged steel blades $\mathrm{V}$ shaped, having serrated or sickle cut edges, and riveted to vibrating bar passing through slotted fingers, 
substantially riveted to the apron or table upon which the cut grain fell in position to be raked, or 'forked off.'

"This Obed Hussey machine cutting in a good average stand of barley, June, 1835, was light draught for two horses and left as clean and as evenly cut stubble behind it as the best of machines now do the same work. But one fault, if any, with this first reaper was the lack of one or more cogs in the driving wheel that gave motion to the sickle, which required the team to walk a bit too fast for teams of habitual, or slow motion.

\section{(Signed) "CLARK LANE."}

Regarding one who became a competitor of Hussey, much can be gathered from the U.

McCormick

Late in the Field

S. Patent Office. McCormick, who came comparatively late in the field, when applying for an extension of his patents made many admissions which were afterwards shown to dispute that he had accomplished a successful machine before Mr. Hussey and others. He tells us in his petition and brief to the Commissioner of Patents that he had operated his machine in some late wheat in the harvest of 1831 , but that, although he was sometimes flattered, he was often discouraged; that he did not make sales or sell rights because not satisfied that the reaper would succeed well. $\mathrm{He}$ 
was not sufficiently satisfied of its being a "useful" machine to patent the reaper; he tells us that its construction and proportions were imperfect and its cutting apparatus defective on account of liability to choke. He admits that the cutting "proved not sufficiently certain to be relied upon in all situations" until "the improvement in the fingers and reversed angle of the teeth of the sickle" shown in his patent of 1845 were adopted. A farmer ordered a machine to be delivered in 1841 , but McCormick "did not then feel that it was safe to warrant its performance." These facts are found in the records of the United States Patent Office. Referring to Mr. Hussey, on whose patent, among others, McCormick's application for an extension was rejected, who proved McCormick's Application to be a factor he must consider, he said: "I did not interfere with him because I did not find him very much in the way, calculated to beat him without, and supposed it might be best to do so." Mr. Hussey, no doubt, took the charitable view and supposed Mr. McCormick to have meant that his proofs would have been sufficient to support him in his own rights. Mr. Hussey, the Quaker, wrote the Board to whom McCormick's application for an extension had been referred, and from his letter I quote:

Rejected 
"In view of all these facts, I feel justified in asking your Honorable Board a decision, which, while it adjudges McCormick's machine according to its merits, will not be prejudicial to my interests, seeing that Mr. McCormick makes no claims to the grand principle in my machine, which makes it valuable, and so much better than his, which principle I claim as my invention.

Mr. Hussey's Attitude

"I had no intention, neither had I any desire, to place any obstacle in the way of the extension of McCormick's patent, but the course he has taken, before your Board and before Congress, has compelled me to act in self defense, by which I have given your Honorable Board much trouble, which I would have gladly avoided."

Mr. McCormick also said to the Board: "If my claim be made out as so far appears from the evidence presented, it will be observed (as I think) that nothing will be left of Mr. Hussey's claim to which he is entitled, and all the improvements he has added since his patent have, I believe, been taken from mine." Reference is no doubt had to the effect that Hussey, in some of his machines, used only a single drive wheel and balanced his machine thereon. He confessed that he never received profits from his first patent until after twelve years of study, and never should have realized anything 
from the invention but for later improvements, and he continues as follows: "If then it shall appear that I am the original inventor of all the leading and important principles of the invention, is it wrong that I should ask for reciprocal benefits for myself, who alone have brought them into being? Mr. Hussey's prior patent stood in Mr. McCormick's way, but its inventor raised no voice against the extension of McCormick's rights unless his prior rights became endangered. The honors due Mr. Hussey were not lessened by the Commissioner of Patents when treating of a competitive claimant to have invented the reaper.

Mr. McCormick took out a third patent in 1847 covering inventions shown by the statement of Leander and others to have been the Not McCormick's Inventions invention of the father or some one else. An application was made for the extension of this patent. It then became necessary that the applicant show that he had not reaped the benefits he believed himself entitled to through his monopoly for the term of the patent.

The value of the second patent that of 1845 , may be gathered from the words of the Commissioner of Patents: "The invention of 1845, considered in itself, and examined in presence of the reaping machine as then in successful operation, both in Europe and America, can

Neither

Brilliant nor Extraordinary 
scarcely be regarded as brilliant or in any degree extraordinary."

The Commissioner further said:

"It was a conviction of the inefficiency of the machine that led the applicant to make his invention of 1847 , which, by a modification of pre-existing elements, provided an advanta-

An Efficient geous location for the raker's seat. Upon this Machine his fame as an inventor rests, and to this is his reaper indebted for the triumphs it has achieved. This seat had been previously known in at least nine patented reapers; but it had not been well placed, and an appropriate location for it was, up to 1847, an acknowledged desideratum. Whatever, however, may have been the value or the success of the reaper as improved in 1847 , such value or success can exert no influence in determining the issue under discussion."

The Commissioner further said, referring to the 1847 patent:

"Without the parts thus slowly accumulated and combined, and which have been so unhesitatingly appropriated by himself, his own McCormick's "Invention" Valueless invention would have been as valueless as would be a shingle to him who could find no house-top on which to nail it. The construction insisted on would compel the public to pay again, and pay extravagantly, for that which 
is already its own, alike by purchase and by long uninterrupted possession."

The authorities cited make it clear the Hussey reaper was successful, from the start, but the Patent Office did not seem to think that the machine of his opponent for honors was so.

The Commissioner in his decision refers to the testimony of William S. McCormick, who, at that time, was a partner of Cyrus McCormick as a manufacturer and seller of the McCormick reaper:

"As a farmer I used the reaper without a seat, before a good one was invented, and am perfectly certain that it was so nearly worthless that a machine without one could not be A Worthless sold at any price that would pay in competition with one having a raker's seat; this is my experience from my intimate connection with the business for many years." (Commissioner's Decision, January 28, 1859.)

I further find :

"In the criticism which has been necessarily made upon the invention of 1845 , there has been no design to detract from the acknowledged value and usefulness of the machine, as constructed under the patent of 1847. It has had its brilliant successes in England and France, but it has also had its marked discom- 
fitures when competing with other machines. Though enjoying a great and perhaps a still expanding popularity, it is by no means a universal favorite."

The last words of the Commissioner are: "The application must therefore be rejected."

There were no questions raised as to the invention of Mr. Hussey.

The statement that McCormick's success was founded upon the inventions of others and to no extent upon his own, as quoted from "Memorial of Robert McCormick," is in part admitted by Cyrus McCormick, who, in his affidavit when applying for the extension of his 1847 patent said: "He has, at the expense of much thought, time, and money, added many other important improvements to it since 1847 , which have contributed to the profits of his manufacture." He then refers to other im-

McCormick Had to Pay for

"Hussey

Improvements

provements, saying: Among such improvements by others as he has had to pay for, are the inventions of his brothers, of Obed Hussey, of Jonathan Reed, of Henry Green, of Solymon Bell and of Joseph Nesen. It is known that Mr. Hussey Did Not Need the Improvements of Others for nearly thirty years Obed Hussey manufactured and sold reaping machines and mowers in his limited way and, infringing no rights of others, had no royalties to pay. To such an extent was his mind that of an inventor, that he devoted thought to many side lines, the ex- 
pense of which taxed his abilities until, when his patent of 1847 had but two years to run, he sold it for $\$ 200,000.00$.

\section{COMMISSIONER'S DECISION}

In the matter of this application of Eunice B. Hussey, Administratrix of Obed Hussey, deceased, for the extension of Reissued Letters Patent No. 449 for an improvement in Reaping Machines, dated the 14th day of April, 1857, being a division and re-issue of original Letters Patent No. 5227, dated the 7th day of August, 1847 , for an improvement in Reaping machines.

Also, the application of the same party for the extension of the Reissued Letters Patent No. 451, for an improvement in Reaping Machines, dated the 14th day of April 1851, being a division and Reissue of Original Letters Patent No. 5227, dated the 7th day of August, 1847, for an improvement in Reaping Machines.

Also, the application of the same party for

Applications of

Mr. Hussey's Widow for Patent

Extension the extension of Reissued Letters Patent No. all Granted 742, for an improvement in Reaping Machines, dated the 21 st day of June, 1859, being a division of Reissued Letters Patent No. 450, dated the 14th of April, 1857, being a division and Reissue of original Letters Patent No. 5227, 
dated the 7th day of August, 1847, for an improvement in Reaping Machines.

Also the application of the same party for the extension of Reissued Letters Patent No. 917, dated the 28th day of February, 1860, for an improvement in Reaping Machines, being a reissue of reissued Letters Patent No. 743, dated June 21, 1859, the last named Patent being a division and reissue of reissued Letters Patent No. 450, dated the 14th day of April, 1857, which last mentioned patent was a division and reissue of original Letters Patent No. 5227, dated the 7th of August, 1847, for an Improvement in Reaping Machines.

These four applications for the extension of the said four patents, Nos. 449, 451, 742 and 917 , having been made in due form on the 30th day of November, 1860 , and the Commissioner of Patents having caused to be published in due and legal form, notice of said applications and of the time and place when and where the same would be considered. And the applicant, the administratrix and widow of the patentee, having duly furnished and filed statements in writing under oath of the ascertained value of the said inventions and improvements claimed in said patents, and of the receipts and expenditures of the patentee and his legal representatives sufficiently in detail to exhibit a true and faithful account of loss and profit in any man- 
ner accruing to the patentee and his legal representatives from and by reason of said inventions and patents. And the testimony in these four cases having been duly filed and considered and referred to the principal Examiner having charge of the class of inventions to which these belong, and the said Examiner having made a full report upon the said cases, and particularly that the inventions or improvements, secured by the said four patents, were new and patentable when patented. And the printed arguments in these cases having been duly filed and considered, and the day of hearing viz. the 28th day of Feb., 1861, arrived, undersigned, the Acting Commissioner of Patents, sitting at the time and place designated in the said published notice to hear and decide upon the evidence produced before him both for and against the extension, and having heard all persons who appeared to show cause why the extension should not be granted, does decide as follows, viz.:

That the applications for extension in these cases were made at a proper time, and not prematurely as the opponents have contended. The only ground alleged to support the allegation that the applications were premature is that the receipts for the year 1861 cannot be fully ascertained at this time, but must be estimated or guessed at. If this is a good rea- 
son for not considering the applications now it would also be good on the 7th of August

Claim of when the patent expires, for the receipts would Opponents not then be ascertained, but would still be the Overruled subject of estimate only. These receipts can be as well determined by this mode now, as in August. The objection on this point is not therefore well taken, and must be overruled. An application for extension cannot be regarded as premature if made during the last year of the term of the patent, and the total receipts are known or can be estimated with reasonable certainty. In addition to this there seems to be no little force in the argument of Counsel that the public convenience would be promoted by an early decision upon these cases before manufacturers enter upon their preparations for another year's business.

Besides these considerations, which of themselves are sufficient to determine the propriety of hearing these cases at the present time, the late Commissioner of Patents fixed this time for these hearings with reference to the public interests therein, and is an additional reason why it should be adhered to, yet I should have no hesitation in postponing the hearing if it were made to appear that the public interest were likely in any way to be subserved by such postponement. 
The report of the Examiner leaves no doubt in my mind as to the novelty of each of the inventions which constitute the subject matter of the four patents for which the extensions are asked. His report is equally conclusive as to the utility of the inventions, their value and importance to the public, and as to the patentee's diligence in introducing them into public use, and his efforts to derive remuneration from their sale.

From a careful examination of all these points myself, I have arrived at the same conclusion as the Examiner.

The Counsel, Wm. N. Whitely, the opponent of these extensions have urged with great pertinacity that the inventions are not novel. They allege that the same thing existed before in Hiram Moore's "Big Harvester" in Michigan-the Ambler Machine in New York-the Nicholson Machine in Maryland-and the White and Hoyle Machines in Ohio. They also contend that the invention claimed in Patent No. 451 especially, is of no utility or value. On a careful review of all these points with the light of the Argument of Counsel, I Opponents Contentions Not Proven by Facts am quite clear that the Examiners conclusion as to the novelty and utility of Hussey's invention are sound. The Moore or "Big Harvester" cutting apparatus, the testimony shows was designated for the performance of a dif- 
ferent duty from Hussey's and could not without essential changes of construction, amounting to changes in its principle and mode of operation, be used for the same purposes as that of Hussey.

The Ambler machine had a straight edge cutter vibrating on arms through barbed or open slotted fingers. His Cutting apparatus lacked an essential element found in Hussey's the scalloped cutter, to say nothing of other material differences. This machine has nothing to impeach the novelty of Hussey's inventions. The Nicholson Model has no vibrating scalloped cutter which is one of the specific elements of Hussey's combination. The White machine as shown in the exhibit produced and which the testimony shows has been recently fabricated is not substantially the same combination claimed in patent No. 742. It has not like Hussey's a cutter with flush edges on both sides of the angle of the forks on the same side of the blade. The Hoyle Machine, according to Hoyle's own deposition, is subsequent in date to Hussey's invention.

It is contended by the opponents that the patent No. 451 has no utility or value. I am

Utility of inclined to the opinion that the utility of the Hussey's improvement specified in this patent is, of itInventions self, small, compared with the improvements covered by the other patents of Hussey now 
before me, which are all of very great utility, and two of them indispensable in the present state of the art. Still since the novelty of the improvement claimed in No. 451, is admitted and is proven by the testimony of Henry $B$. Renwick to have some utility as one of this series of patents, I think it has sufficient utility to justify an extension.

The contestant's counsel have argued from the testimony of Lovegrove, that Hussey abandoned his inventions to the public by having them on sale more than two years before applying for a patent. The testimony does not sustain this point. Besides, an inventor does not abandon his invention to the public by constructing a machine embracing it, in the Mr. Hussey Did Not same factory where he makes and sells other Abandon machines. Nor by using it experimentally in His such a factory or elsewheres. Nor by keeping it in such a factory from the autumn of one year to the harvest of the next year. Nor by doing all or any of these things more than two years before his application for a patent.

The statement of receipts and expenditures is unusually full and in detail, more so than is necessary to fulfill the requirements of the law.

There are two classes of expenditures and two corresponding classes of receipts, viz.: 
1st. Expenditures and receipts on account of the manufacture and sale of Reapers and Mowing Machines embracing the patentee's improvements.

2nd. Expenditures and receipts on account of the sales of Patent rights and licenses, and compromise of infringements.

The Patentee manufactured and sold about 2,000 machines, and a few other articles at a cost of materials and labor..... \$ \$195,292.88 Shop and Tools............ 12,500.00 One-quarter of patentee's time and expenses $\ldots \ldots \ldots \ldots \ldots$

$9,008.22$

$\$ 216,801.10$

The receipts on account of the sale of these manufactures were:

Cash for Reapers .......... \$216,607.90

Cash for parts of Reapers..... 22,416.58

Notes and Book Accounts..... 11,388.23

Cash for Corn Crushers........ 1,135.25

Discount and Interest....... 2,327.84

$\$ 253,875.80$

The result of the manufacturing business is an excess of receipts over expenditures of $\$ 37$,074.70. This statement, however, allows nothing for manufacturer's profits. An allowance 
for such profit ought to be made but in this case the object is to eliminate from the gross receipts such profits as have in any manner accrued from or by reason of the inventions claimed in the patents. Now receipts or profits that result from business talents or skill in manufacturing or in financeering are not receipts or profits in any manner accruing from or by reason of an invention. In the case of Seymour and Morgan vs. McCormick-Howards Reports Vol. 16 p. 480, the Supreme Court of the United States held that the ruling of Judge Nelson that the whole profits of the manufacture of Reaping machines in which one small part of the machines infringed a patent was to be considered as accruing from the use of the patented part was erroneous, and that a reasonable manufacturer's profit for the use of the Capital so, in addition to the actual cost of the machine must first be deducted from the gross receipts, and if then there was any excess, that might be assigned to patents. This decision I should deem binding and conclusive upon the subject even if I did not think that the values of business capital and talent are as fairly charges against the receipts of business as the values of a business house or tools.

In this case there is only an excess of $\$ 37,-$ An 074.70 of the receipts over the expenditure or something less than 14 per cent upon the gross Inadequate Profit 
amount of sales. This is a very inadequate profit for manufacturing and selling, but it is all there is, and it is all that I can allow.

If the excess of the receipts over the expenditures had amounted to three times fourteen per cent, I should have had no hesitation in allowing the whole of it for manufacturer's profit, and should not have deemed it more than a reasonable allowance in view of the testimony of Long, which shows that his firm have made a profit of over fifty per cent after paying patent fees, on their manufacture of reapers.

It seems to be supposed from the reference which has beeen made to Commissioner Holt's decision in the case of McCormick's application for the extension of his patent of 1845, that he entertained views at variance with those I have expressed as to the justice of allowing manufacturer's profits as a part of the expenditure, and as an offset against the receipts, but a careful examination of that opinion will show clearly that Mr. Holt was not willing to allow a charge for the use of Capital, and for wear and tear of machines (which are the Constituent elements of a manufacturer's claim to allow for profit) and then, again allow a second or duplicate charge for the same things under the name of manufacturer's 
profits. This is the extent to which Mr. Holt goes, and I fully agree with him.

The expenditures on account of the patents and the sale of rights and licenses under the same are:

For three quarter of patentee's

labor and expense......... $\$ 27,024.68$ For sundry legal and traveling

expenses $\ldots \ldots \ldots \ldots \ldots \ldots \ldots \quad 44,562.88$

$\$ 71,587.56$

The receipts on the same account are:

Cash for licenses, sale of rights,

etc. $\ldots \ldots \ldots \ldots \ldots \ldots \ldots \ldots \quad \$ 92,788.38$

Notes and unsettled accounts.... $\quad 23,748.89$

License fees estimated for 1861 . $\quad 10,000.00$

$\$ 126,537.27$

Showing that the receipts exceed the expenditures by $\$ 54,949.71$ or $\$ 13,737.42$ for each of the four patents.

This I can have no hesitation in pronouncing to be a totally inadequate compensation for inventions of such great value and importance.

After a most laborious examination and careful consideration of the whole matter, it appears to my full and entire satisfaction, hav- 
ing due regard to the public interest therein, that it is just and proper that the term of the said reissued patents No. 449, No. 451, No. 742 , and No. 917 should severally be extended by reason of the patentee, without fault or neglect on his part, having failed to obtain from the use and sale of his said inventions a reasonable remuneration for the time, ingenuity and expense bestowed upon the same and the introduction thereof into use.

Hussey's

Inventions

the Basis of all Reaper

Manufacturers Profits

The list of licenses under these patents show the acquiescence of the principal manufacturers in the justice of Hussey's claims. The list shows that the manufacturers of Reapers have made large profits, and that Hussey's improvements are the foundation of their success. It is certainly just and equitable that Hussey's heirs should be allowed to participate in the advantages of using his own inventions to an extent more nearly commensurate with the merits of those inventions.

The character of the opposition to these applications, in which but a single manufacturer has entered an appearance is such, as greatly strengthens this view, and I feel constrained

A Merited Tribute from the U. S. Patent Office to regard this tacit assent, of the great body of manufacturers to these applications for extension, an additional evidence of the soundness of my own conclusions. As it is also a fitting and merited tribute to Obed Hussey, now in his 
grave, for the invaluable contributions his genius and industry have made to the improvements of the age.

The said four patents, Nos, 449, 451, 742 and 917 , are accordingly extended for the term of seven years from the 7th day of August, 1861.

S. T. SHUGERT,

Acting Commissioner of Patents.

United States Patent Office,

Mar. 1, 1861.

\section{A BRIEF NARRATIVE OF THE INVENTION OF REAPING MACHINES}

And an Examination of the Claims for Priority of Invention

The object aimed at in this examination is to ascertain as far as reliable evidence within reach will establish the fact-and before the evidence may be lost-to whom belongs the credit of first rendering the Reaping and Mowing Machine a practical and available implement to the American farmer; not who theoretically invented a machine for the purpose, that may have worked an hour only, and very imperfectly for that short period, and was then laid aside; but who rendered it an operating and efficient machine that was proved by successive years in the harvest field, capable of 
doing its work, and doing it well; better than either the scythe or cradle.

The object is not to detract from the merits fairly claimed by any inventor; but it is to examine into some of the rival claims, furnish the evidence that has satisfied our own minds, and leave it for others to judge for themselves. We would not intentionally deprive an inventor of his often dearly bought and hard-earned fame-the creation of his own genius-for it is more prized than even fine gold by many. But it is equally just that merit should be acknowledged, and the meed of praise awarded, where it is honestly and fairly due; and to this end we propose and intend to examine into the evidence closely and critically. It may also be right to remark that we have no private or pecuniary interest whatever, in these, or any other patent claims.

As to the theoretical portion of the business, the enquiry might be greatly extended; indeed for past centuries, as we have imperfect accounts of Reaping Machines being used by the Attempts Romans. If the ancients were successful in of the making a practical implement for Reaping, by Ancients horse, or ox power, as some ancient writers assert, we certainly have no correct and reliable account of a machine that would be considered efficient or useful at the present day; a machine to save or tear off the heads only-as 



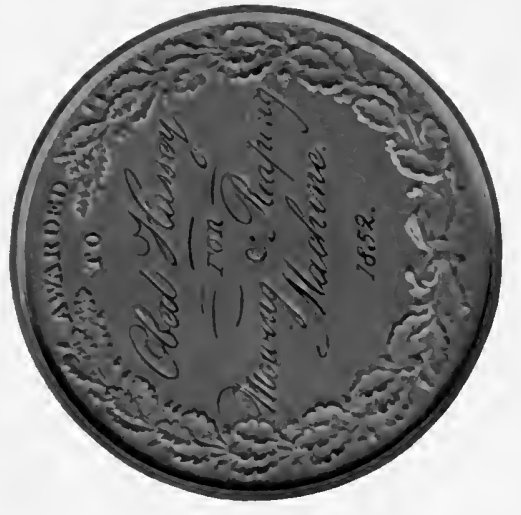

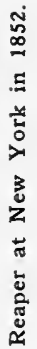

导

点

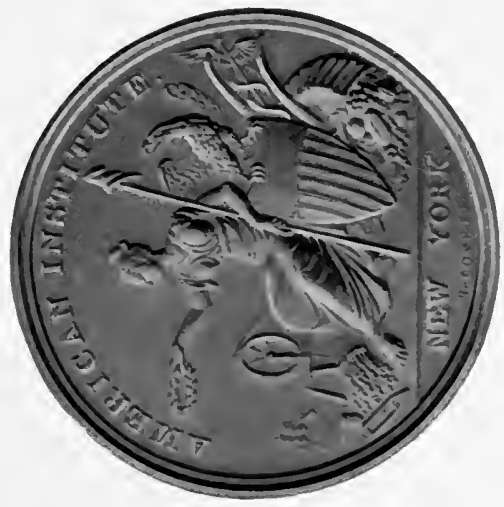

号

L

i

동

"ृ

E

$\stackrel{5}{5}$ 
described by Pliny and Palladius-would more properly be termed a gathering machine, and not at all suited to the wants and habits of modern farmers.

It was not until near the close of the past, and within the present century, so far as we can learn, that the subject again claimed much attention of the inventive talent of either this, or foreign countries. Of some half a dozen or more attempts made in Great Britain, and recorded in Loudon's Encyclopedia of Agriculture, the Edinburg Encyclopedia, and other similar works, all, or nearly all, relief either upon scythes or cutters, with a rotary motion, or vibrating shears. And although there was English Endeavors "go ahead" about them in one sense of the term, as it was intended for the "cart to go before the horse," none of them appeared to have gained, or certainly not long retained, the confidence of the farmers; for at the exhibition of the "World's Fair in London," the whole Kingdom could not raise a Reaping Machine;-a practical implement which was considered worth using and exhibiting.

That the idea was obsolete there, and had been unsuccessful, is clearly proved by the fact that the English journals and writers of that period, without a single exception, spoke of the American Reapers-after the trials!-as "completely successful"- "taking every one by 
surprise"- "their reaping machines have astonished our agriculturists"-_"few subjects have created a greater sensation in the agricultural world than the recent introduction into the country of the reaping machines"-the "curiosity of the crowd was irrepressible to witness such a novelty, even to stopping the machine, and trampling the grain under foot," etc., etc.Much more and similar evidence is at hand; but better need not be produced to prove the entire failure of reaping machines in Great Britain, as late as 1851 . We would also refer the curious to Rees' Cyclopedia, for a very brief account of what had been effected;-a few paragraphs only are written on reaping machines, but several pages are compiled as to the use of the scythe, sickle or reap hook, and reaping fork. The Doctor refers to Plunknett's Machine by name, as being "somewhat on a new principle, the horse drawing the machine instead of pushing it forward as was the old mode of applying the power." The machine is fully represented in the Farmers' Dictionary; and he winds up the account as follows: "But the success with which they have been attend-

English Failure ed has hitherto been far from complete;" again, "Other machines of this kind have still more lately been invented by other persons [meaning of course his own countrymen] but without answering the purpose in that full and com- 
plete manner which is necessary in this sort of work."

The Doctor undertakes to tell us what is wanted, but fails entirely to inform his readers how to do it. That John Bull had not done it is clearly established; but Brother Jonathan, the "Live Yankee," as John calls his cousin, has solved the problem; and the solution is so simple, when you know how to do it! that it is marvelously strange no one for centuries had before struck upon the right key.

Philip Pusey, Esq., M. P. and F. R. S.-the chief manager of the London Exhibition-admits the failure, though apparently reluctantly; but the source of his information, in writing about the American machines, was interested and defective; and when he again writes on this subject he will be better informed. He says: "At the opening of this century it was thought that a successful reaping machine had been invented, and a reward had been voted by Parliament to its author. The machine was employed here and abroad, but from its intricacy, fell into disuse. Another has been lately devised in one of our Colonies, which cuts off the heads of the corn, but leaves the straw standing, a fatal defect in an old settled country, where the growth of corn is forced by the application of dung. Our farmers may well, therefore, have been astonished by an Amer- 
ican implement which not only reaped the wheat, but performed the work with the neatness and certainty of an old and perfect machine. Its novelty of action reminded one of seeing the first engine run on the Liverpool and Manchester railway in 1830 . Its perfection depended on its being new only in England; but in America the result of repeated disappointments and untired perseverance, etc."

We propose to prove, and by better evidence, and disinterested too, than he then had, that in 1833, near the date of "the first engine run on the Liverpool and Manchester railway in 1830," the American machine cut the "corn" just as perfectly, with equal "neatness and certainty" as did the "Novelty" or "Rocket" pass over the Liverpool and Manchester railway. We shall again recur to English authority. John Bull is a right honest and clever old gentleman in the main; but he is rather prone to claim what he has no title for-inventions, as well as territory. We are willing to give him what he can show a clear deed for, but no more.

English Claims He beat us by one year only in the Locomotive; but we fairly beat him eighteen or twenty in the Reaping Machine; and yet some of his writers contend to this day that we "pirated" from Bell and other English inventors all we know! 
The excitement and sensation thus produced by the American Reapers, caused renewed efforts on the part of English inventors; some who had near a quarter of a century previously, been endeavoring to effect this "great desideratum," to use an English editorial; and the most conspicuous of these was one invented by the Rev. Patrick Bell, of Scotland. Of the half a score or more and previous inventors in Great Britain-Boyce, Plunknett, Gladstone of Castle Douglass, Salmon of Waburn, Smith of Deanston in Perthshire, etc., etc.-none were waked up from their Rip Van Winkle slumbers; or if they were, the world is not advised of it. They all used revolving scythes, revolving cutters, or shears instead. Several trials were made with Bell's in 1828 or 1829 ; and a very full and minute description with plates, English Inventors and Their Mistakes was published some 24 or 25 years ago, and may be found in Loudon's Encyclopedia of Agriculture.

It was, however, too complicated, too cumbersome and expensive, performed too little service, and required too much tinkering and repairs to be viewed as a practical and available implement.-The English farmer found the sickle or reap hook preferable, for it was everywhere resorted to.--The cutting apparatus of Bell's consisted of shears, one half stationary, the other vibrating, and turning on the bolt 
that confined them to the iron bar which extends across the front of the frame. The vibrating motion was given by connecting the back end of one shear to a bar-making the bolt the fulcrum-and which was attached to a crank, revolving by gear to the driving wheels.

A reel was used to gather the grain to the shears, and adjustable, back and forth, and Bell's higher or lower, to suit the height of the grain. Machine A revolving apron delivered the grain in a continuous swath; and the team was attached to the rear of the machine, pushing it through the grain.

We have been more minute in the description of Bell's machine, because it may have been the foundation of some of the early, and nearly simultaneous attempts made in this country. In fact it does not admit of doubt that several were nearly identical with Bell's in the use of the shears and reel, though with much more simple gearing, and in the general arrangement. Whether they were original inventions, cannot be ascertained. In this country, from 1800 to 1833 out of some 15 or 20 patents granted for "cutting grain" and "cutting grass," only four appear to have been "restored"; i. e. technically speaking, "not restored" in models and drawings after the burning of the Patent Office in 1836. Many, if not 
most of them, were probably improvements in the grain cradle, and mowing scythe; though the names are preserved, there is no record to show for what particulars the patents were granted. There can be no doubt, however, that the inventors considered them valueless, as they were "not restored," though Congress voted large sums to replace the burnt models and drawings, without any expense to the parties. Of those restored James Ten Eyck's patent is dated 1825, Wm. Manning's in 1831, Wm. \& Thos. Schnebly's in 1833, and Obed Hussey's also in 1833.

James Ten Eyck used an open reel; not only to gather the grain, but his cutters or shears, were attached to, and revolved with the reel;-very much, if not exactly on the principle of shearing cloth.

William Manning used another form of cutters, and quite different from James Ten Eyck's -he likewise used fingers or teeth to support the grain during the action of the horizontal cutters.

William and Thomas Schnebly of Maryland also used the reel, with shears as cutters, very similar to Bell's.

Abraham Randall, or Rundell, of New York (for the name is spelled both ways), was another of the early inventors. His patent of 1835 is not restored, though it is stated his ma- 
chine was experimented with as early as 1833 or 1834. He also used the reel, and his cutters, it is said, were similar to Bell's-using shears.

T. D. Burrall, of New York, was also one of the early inventors, about 1832 or 1833 , but we believe professedly after Bell's, so far as to use a reel and shears.

None

None of these machines, however, Hussey's Successful excepted, were successful, or were used any length of time; nor is it necessary here to refer particularly to other attempts, about this time, or indeed prior to this period, for they were equally unsuccessful; and their inventors cannot claim the merit of doing a thing, that was not in fact performed-making an efficient and successful Reaper. We may here remark, however, that so far as now known, no machine like Bell's, on the shear or scissor principle, has succeeded in this country; or as we believe, is ever likely to succeed. We have seen a number by different inventors, and all have failed to give satisfaction. They may work well for a very brief period and with keen edges; but as they become dull, the shears are forced apart by the straw and grass-particularly the latter, and the machine fails, as it inevitably must do, in its allotted duty, and for very obvious reasons. If the shear rivet or bolt is kept tight there is too much friction; if loose enough to play freely it is too loose to cut well; and, last- 



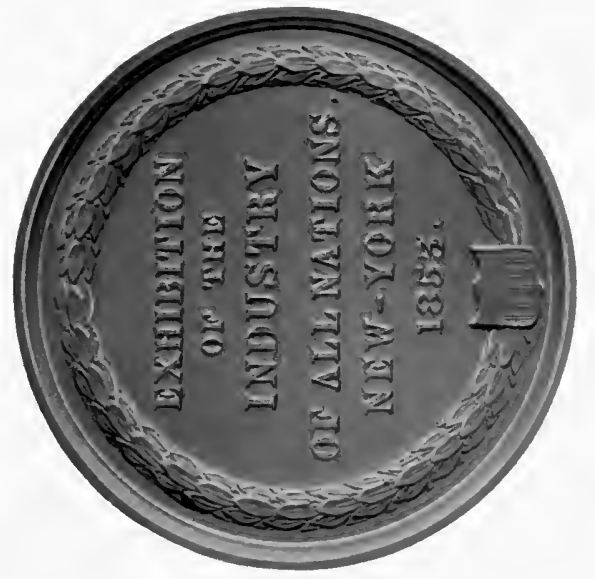

告

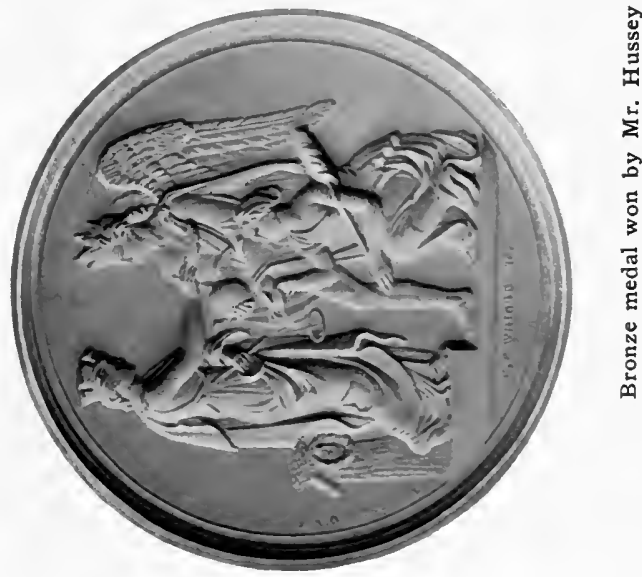


$1 y$, it is too liable to wear at the most important point of the whole machine. During the harvest of 1853 in England every effort was made to uphold Bell's machine; in some cases prizes were awarded to it, though evidently partial; for in the face of these awards some who witnessed the trials, and had used Bell's machines, laid them aside and purchased Hussey's. At the close of the season, as we learn from reliable authority, even the engineers who operated Bell's, frankly admitted that the American machine as exhibited by Hussey, was the better implement, owing to the arrangement of the guards and knives; Bell's required so much tinkering, that several machines were required to cope with one of Hussey's. At the recent harvest (1854) the Mark Lane Express acknowledges that the Royal Agricultural Societies' show at Lincoln, Bell's machine was "at Hussey's Machine an American Triumph last fairly beaten" by Hussey's, including McCormick's, and Hussey's machine received the prize over all others. It is just, however, to add, that far as we consider Bell's machine behind some of the present day, yet complex and cumbersome as it was, it combined more of the essential features of success than any Reaper that preceded it.

We now come to 1833, the date of Hussey's patent; and to 1834 , the date of C. H. McCormick's first patent. These were known and ad- 
mitted by all to have been the rivals for popular favor and patronage, from about the year 1844 or 1845 to the opening of the great Industrial Exhibition in London, in 1851. To these, therefore, the enquiry will be more particularly directed.

We must, however, refer back for a brief period to 1831 ; for although C. H. McCormick's first patent was dated in 1834 , yet when he applied for his extension in 1848 he alleged that his invention was prior to Hussey's, as he had invented a machine in 1831, two years before the date of $O$. Hussey's, and three years before'the date of his own patent. The evidence produced written and prepared by $\mathrm{C} . \mathrm{H}$. McCormick and now on file in the Patent Office) was deemed inadmissible and informal by the Board, and it refused to go on with the examination either as to priority or validity of invention without notice to Hussey-his patent being called in question by McCormick-to be present when the depositions were taken.

McCormick's

Attempt to Get Hussey's Signature

Before, however, receiving the official notice, he was called on by C. H. McCormick in Baltimore, and requested to sign a paper, agreeing or admitting, that the testimony he had himself prepared should be considered evidence-i. e. considered formal; alleging that it would save him trouble and expense in going to Virginia. This was declined by Hussey on 
the ground that he might thus unwittingly injure himself; he having previously applied for an extension of his own Patent. Neither was he then aware of the nature of this evidence; or until this interview, was he advised of C. $\mathbf{H}$. McCormick's application for extension.

Hussey was subsequently duly notified by order of the Board to be present at taking the depositions in Augusta County, Virginia,- the Board having adjourned three weeks for that purpose.

Either just previous or subsequent to these proceedings the case was referred by the Commissioner of Patents, or Board of Extensions, to Dr. Page, one of the Examiners of the office.

His report is as follows:

"Patent Office,

"Sir : "Jan. 22d, 1848.

"In compliance with your requisition I have examined the patent of Cyrus H. McCormick, dated 31st June, 1834, and found that the principal features embraced in said patent, viz, the cutting-knife and mode of operating it, the fingers to guide the grain and the revolving rack for gathering the grain, were not new at the time of granting said letters patent.

"The knife-fingers and general arrangements and operation of the cutting apparatus 
are found in the reaping machine of 0 . Hussey, patented 31st Dec., 1833.

"The revolving rack presents novelty chiefly in form, as its operation is similar to the revolving frame of James Ten Eyck, patented 2nd November, 1825.

\section{"Respectfully submitted, \\ "CHAS. G. PAGE, \\ "Examiner.}

"Hon. Edmund Burke, Com'r of Patents."

As some have enquired, and others may enquire, why a patent should issue under these circumstances, we reply, that previous to 1836 but little, if any, examination was made as to priority of inventions, or into preceding Patents; the applicant made oath as to his invention, and the patent was issued as a matter of course. And as another matter of course, if the rival interests clashed, litigation was the result:- the Courts and juries often decided what they little understood, and at times not at all, after the pleading of well fee'd lawyers; a pretty fair illustration of the fable of the boys and frogs; it may be fun for the lawyers but it is death to the hopes of many a poor patentee. We are, however, pleased to perceive a disposition manifested by the courts to sustain patents; even if occasionally an unjust claim is recognized as a valid one, it is better, according 
to the legal and moral maxim, that half a dozen rogues should escape punishment for a time, than that one innocent person should be unjustly convicted; the rogue is almost certain to be caught in the end, and truth will ultimately triumph.

This testimony was taken in due form at McCormickSteele's Tavern, Augusta County, Va., McCormick and Hussey both being present. It is too Hussey Coutroversy voluminous to copy entire, but we will refer briefly to each, having read them carefully, and obtained certified copies of all from the Patent office.

Dr. N. M. Hitt testified to a reaping machine being made by $\mathrm{C}$. $\mathrm{H}$. McCormick in 1831 -it had a straight sickle blade.

William S. McCormick and Leander J. McCormick, brothers of C. H. McCormick, also testified to the making of a machine in 1831.

Mary McCormick, mother of C. H. McCormick, agreed in general with the testimony of her sons, - did not doubt but it was correct, "it appears familiar to me," but testified to nothing in particular.

John Steele, Jr., was tavernkeeper at Testimony "Steele's Tavern," testified as to the year being 1831 or 1832 . In his amended testimony, admitted that C. H. McCormick wrote the paper describing the machine for him to testify to; 
recollects little else about the machine than the straight sickle edge.

Eliza H. Steele refused to testify without first seeing a certificate previously signed by her; admitted that C. $\mathrm{H}$. McCormick wrote it for her to sign; her testimony as to the year depended on the building of a certain house, on which the workmen put 1831 .

John McCown-was a blacksmith-testified that he made the "straight sickle blade," and that it was "a long, straight sickle" blade.

This was most singular testimony to found a claim of priority of invention on, and by which to invalidate another man's patent. There was discrepancy in the evidence as to the year of the invention; also whether the machine was intended for one or two horses; how the "fingers" were arranged, and whether of wood or iron, above or below, the "straight sickle blade." Two of the brothers-one at least who helped to make, if not also to invent this machine-testified that the plan or arrangement of the machine here sworn to, was changed in $1840,1841,1842$, or 1843 , they did not know which; from 9 to 12 years afterwards!

John McCown swears positively that he helped to build the machine, so far at least as to forge "a long, straight sickle;" but neither he, or a single one of the seven sworn wit- 
nesses, "Iadies and gentlemen," testify that the machine ever worked a single hour, or cut as much grain of any kind as would make a single sheaf!*

In a long communication to Commissioner Burke in 1848, together with a list of sales and profits, C. H. McCormick states, and on oath, that he had exhibited his machine in 1840 or 1841 to a considerable number of farmers and very satisfactorily, though but one person could be induced to purchase-a Mr. John Smith we believe-and that up to 1842 , eleven years after the alleged invention, he had sold but two machines, and one of them conditionally. Again, in the same paper he states, "but they failed to operate well," and had to be altered-in other words they would not work at all. Amongst others, he had applied to "the

"John Smith"

- The reading of this testimony strongly reminds us of an anecdote related at the hustings in Virginia by that talented but eccentric character, John Randolph, of Roanoake, in a political canvass with an opponent, who promised what he would do for his constituents, if elected. Randolph told him he was like one of his overseers, a plausible fellow, but on whom little reliance was to be placed-and who, desiring to show what fine crops he had raised, exhibited a better tally board than the crop could justify. "I told him," said Randolph, "this is very good tally, John, but where's the corn? and I tell the gentleman, I don't want to see his tally, but the corn-the evidence of what he ever did to entitle him to a seat in Congress." The effect was electric, and the hustings rang with plaudits. Now we would say to C. H. MeCormick, this is very good tally, John, but where's the Corn? The evidence that the machine ever cut a single acre of grain. 
farmer of Virginia, Mr. Sampson," for a certificate as to the satisfactory working of the machine, but it was declined.

We are not surprised at this; for some 35 years ago we were personally acquainted with this "farmer of Virginia," and also with his mode of farming; and know that a machine of any kind to please him must work and must also work "well." Richard Sampson was at that early day in this "age of progress," one of the best and most practical farmers in the "Old Dominion," and was not a man to be "caught napping," either at home or abroad.

The record shows that "on March 29, 1848, the Board met agreeably to adjournmentPresent, James Buchanan, Secretary of State, Edmund Burke, Commissioner of Patents, and R. H. Gillett, Solicitor of the Treasury-and having examined the evidence adduced in the case decide that said patent ought not to be extended."

(Signed) "JAMES BUCHANAN, "Secretary of State, "EDMUND BURKE,

"Commissioner of Patents.

"R. H. GILLETT,

"Solicitor of the Treasury."

This evidence, taken in due form, and certified to by the magistrates in Augusta and Rockbridge Counties, Virginia, was not ruled out as 
informal, as we have seen it stated: but it was certainly laid before the Board; and was doubtless satisfactory both as to priority of invention, and in connection with Dr. Page's report, conclusive, "that said patent ought not to be extended."

We have also seen it stated that Hussey appeared before the Board of Extensions "to contest the extension of McCormick's patent."

We think injustice-and no doubt unintentionally-is here done to Hussey. Until the order of the Board was passed to afford him the opportunity to defend his rights, assailed without his knowledge, he was not aware of $\mathrm{C}$. $\mathrm{H}$. McCormick's application. As a matter of course he then attended, but stated in writing, and which is now on file, "I had no intention, Mr. Hussey Acted in Self Defense neither had I any desire to place any obstacle in the way of the extension of C. H. McCormick's patent. But the course he has taken before your Board and before Congress has compelled me to act in self defense."

Not so with C. H. McCormick; for when his claims were rejected by the Board of Extensions,-and most justly, as we think, in accordance with the evidence-he petitioned Congress against Hussey's extension: and to this most ungenerous, illiberal and unfair course, McCormick Assailed the Hussey Extension and of which Hussey was for years totally ignorant, C. H. McCormick may justly attribute 
this enquiry;-but for this, it had never been written. Our object is not to injure C. H. McCormick; but it is that justice may be done to another, whose interests and rights he was the first to assail.

If the foregoing testimony is not conclusive, as regards priority of invention in 1831 against C. H. McCormick, we think the evidence which follows-and which no one will pretend to call in question, or doubt-establishes the fact that the machine of 1831 was good for nothing,not even half invented; and that the machine of 1841 was not much more perfect.

On page 231 of the Reports of Juries for the Great London Exhibition, and now in the Library of Congress, we find the following:

"It seems right," says Philip Pusey, Esq., M. P., "to put on record Mr. McCormick's own account of his progress, or some extracts at least, from a statement written by him, at my request."-[Pusey.]

"My father was a farmer in the county of Rockbridge, State of Virginia, United States. He made an experiment in cutting grain in the year 1816 , by a number of cylinders standing perpendicularly. Another experiment of the same kind was made by my father in the harvest of 1831 , which satisfied my father to abandon it. Thereupon my attention was directed to the subject, and the same harvest $I$ invented 
and put in operation in cutting late oats on the farm of John Steele, adjoining my father's, those parts of my present Reaper called the platform, for receiving the corn, a straight blade taking effect on the corn, supported by stationary fingers over the edge, and a reel to gather the corn; which last, however, I found had been used before, though not in the same combination.

"Although these parts constituted the foundation of the present machine, I found in practice innumerable difficulties, being limited also to a few weeks each year, during the harvest, for experimenting, so that my first patent for the Reaper was granted in June, 1834.

"During this interval, $I$ was often advised by my father and family to abandon it, and pursue my regular business, as likely to be more profitable, he having given me a farm. [Italicised by C. H. McC.]

"No machines were sold until 1840, and I may say that they were not of much practical value until the improvements of my second patent in 1845 .

"These improvements consist in reversing the angle of the sickle teeth alternately-the improved form of the fingers to hold up the corn, etc.-an iron case to preserve the sickles from clogging-and a better mode of separating the standing corn to be cut. Up to this 
period nothing but loss of time and money resulted from my efforts. The sale has since steadily increased, and is now more than a thousand yearly."**

It would be just as conclusive and reasonable for the father of C. H. McCormick to claim at this day priority of invention for his Reaper invented in 1816, "by a number of cylinders standing perpendicularly;" or for "the invention made by my father in the harvest of 1831 , which satisfied my father to abandon it." This authority, high and official as all must admit it to be, [and italicised too, by the writer for a particular object,] clearly proves that the invention of 1831 was an abortion; for if the principle was effective to cut one acre of grain properly, any man of common sense knows that it was equally so to cut one thousand acres;

* "The sale has since steadily increased, and is now moro than a thousand yearly." This was written in 1851 , and by a little calculation, we can readily estimate the "yearly" profits. In the Circuit Court of the United States, at Albany, in the suit brought by C. H. McCormick against Seymour \& Morgan, in 1850, for an alleged infringement of patent, it was proved on the oath of $O$. H. Dormon, his partner, and also on the oath of H. A. Blakesley, their clerk, that these Reapers only cost $\$ 36$ to $\$ 37$ to manufacture. By the same evidence, the sales averaged from $\$ 110$ to $\$ 120$ each machine; leaving a clear profit of at least \$73. C. H. McCormick first received a patent fee of $\$ 30$ on each machine, then three-fourths of the remainder in the division of profits. It would thus appear, if these figures are correct-and they are all sworn to-that C. H. McCormick realized full fifty thousand dollars clear profit annually, with a margin of eight to ten thousand dollars for commissions and bad debts in addition. 
but so complete was the failure that, "During this interval"-between 1831 and 1834-" $I$ was often advised by my father and family to abandon it, and pursue my regular business, as likely to be more profitable, he having given me a farm."

Again, "No machines were sold until 1840, and I may say that they were not of much practical value until the improvements of my second patent in 1845." What these improvements were we are also informed: "These improvements consist in reversing the angle of the sickle teeth alternately, the improved form of the fingers to hold up the corn, etc.-an iron case to preserve the sickle from clogging, etc.up to this period nothing but loss of time and money resulted from my efforts."

Nor is it at all surprising ; for until improvements were added, invented and long in successful operation by others, the machine would not work, and consequently no one would buy.

This letter is the most perfect and complete estopper to priority of invention-not only for 1831 , but to 1841 inclusive, if not to 1845 , that could be penned. His pen cuts a "cleaner swath," as we farmers say, than ever did his Reaper; and this letter at least is certainly $\mathbf{C}$. H. McCormick's own "invention," which no McCormick's Pen More Effective Than one else can lay any claim to. Yet, strange as it may appear, he contended before the Board His Reaper 
of Extensions in order to invalidate Hussey's Patent, that he invented a Reaping Machine nine years before! So has perpetual motion been invented a hundred times-in the estimation of the projectors; and by his own showing, and on oath, he sold but two machines up to 1842 - one of them conditionally sold-being eleven years after the alleged invention, and even they had to be re-invented to make them work, or use the previous inventions of others.

In this letter to Philip Pusey, Esq., M. P., C. H. McCormick admits that the Reel "had been used before," yet he includes it in his patent of 1834.-Both the specifications and drawings in the Patent Office conclusively establish the fact that James Ten Eyck patented the reel or "revolving rack," or "revolving frame" in 1825, used not only to gather the grain as all such devices are used, but by the knives attached to it, also intended to cut it off.

Could it be contended that because rockers are attached to a chair it is no longer a chair, or useful as a seat? Even "Mary McCormick, the mother of Cyrus," and "Eliza H. Steele, of Steele's Tavern, Virginia"-nay every woman and child in the country would tell you that it was then a rocking chair-just as much a seat as ever-and Ten Eyck's was a Reel to all intents and purposes, but also a cutting reel. It does not require the mechanical tact and skill 
of Professor Page to discover that "the revolving rack presents novelty chiefly in form, as its operation is similar to the revolving frame of James Ten Eyck, patented November 2d, 1825." It is certain the reel was no "novelty," either in 1831 or 1834 , when patented by C. H. McCor- Priority mick; he tells us so himself; and it is most of the Reel likely the father of C. H. McCormick also used a reel for his "cylinders standing perpendicularly, in 1816," and also for his other plan in 1831, and "which satisfied my father to abandon it." And it is equally probable that most of the "fathers" and the sons, who invented Reapers for a hundred years preceding the date of Hussey's patent, used reels;-indeed the reel seemed to be considered a Sine qua non by many; most of the inventors we have any clear account of, resorted to the reel.

Hussey also used the reel in 1833-of course the reel and seat in combination-but only for a short period, as it was found quite unnecessary-an actual incumbrance with his cutting apparatus, and soon laid it aside.

We will now examine another invention patented by C. H. McCormick, in 1847. We here assert and challenge a denial, that from 12 to 14 years after the alleged invention of a Reaper by C. H. McCormick in 1831, and from 9 to 12 years after the date of his patent in 1834 his raker walked by the side of his machine, 
while Hussey's raker rode on the machine as they always had done since his first machine that cut the grain like "a thing of life" in Hamilton County, Ohio, in 1833 . Yet, in 1847, C. H. McCormick takes out a patent for the raker's seat! this was a "novelty" and well worth a patent!

In two trials of reaping machines by Hussey and McCormick in the same fields in Vir-

The Raker's

Seat ginia, in 1843, one at Hutchinson's, and the other on the plantation of the late Senator Roane, at Tree Hill, near Richmond, McCormick's raker walked by the side of the machine, while Hussey's rode on the machine, in the same manner as he did just exactly ten years before.

We have three letters from the late Hon. William H. Roane referring to these trials, and ordering a machine from Hussey, after witnessing the operation of both. Two of the letters he desired might not be published; but says in one of them, "I have no objection to your stating publicly that a member of the committee who made the report last summer at Hutchinson's, which was published a few days thereafter, witnessed a fuller and fairer trial between the two machines, and has in consequence ordered one of yours. * * * What I have said above of _— is intended only for your eye confidentially, to show you in part the charac- 
ter and probable motives of the opposition your Reaper has met. Let what I say be private, as I have a great objection to going into the newspapers. Should you ever want it, you can have from me the strongest public testimonial of my good opinion of your machine."

The third letter, giving this "testimonial," was published in the American Farmer in January, 1844. As the Raker's Seat-the main feature of C. H. McCormick's patent of 1847comes fairly within the scope of this enquiry as to priority of invention, we re-publish Senator Roane's letter and also furnish other testimony on the subject.

"To the Editor of the American Farmer:

"As the question of which is the best Reaping Machine is of no little importance to wheat growers, it is highly necessary that they be rightly informed of every fact which tends to decide the question. The trial which forms the subject of the following correspondence was looked forward to with great interest by farmers; such was the partial character of the trial, and the general terms of the committee's report, in which the particulars that led to the result were omitted, it cannot appear strange that the public should be in some degree misled with regard to the relative merits of the two machines. If my own interest was alone con- 
cerned, I would not thus far trespass on your columns, but you will doubtless agree with me, that it is due to wheat growers throughout the country that the views expressed by Mr. Roane, in connection with the committee's report, should be published as extensively as the report itself; I therefore solicit the insertion of the following correspondence in your paper.

\section{"Very respectfully,}

"OBED HUSSEY."

"Baltimore, January 18th, 1844.

"To the Hon. William H. Roane:

"Dear Sir-You will remember that a trial took place on the farm of Mr. Hutchinson near Richmond, Va., in July last, between my reaping machine and Mr. McCormick's, at which trial you were one of a committee which gave

Hussey

Letter to Mr. Roane the preference to Mr. McCormick's machine.

"You will also recollect that the machine which I used at that time was a small one, and quite different from that which $I$ used in your field a few days afterwards in a second trial between Mr. McCormick and myself.

"As the first trial was made under circumstances unfavorable to myself, owing to the difficulties which prevented me from getting my best machine to the field on that day, and other impediments incidental to a stranger un- 
provided with a team, etc., and as no report was made of the second trial, you will oblige me by informing me what your impressions were after witnessing the second trial.

"I would very gladly embrace the opportunity which the next harvest will afford of following up my experiments in wheat cutting in Virginia, but the new field opened to me in the great west for cutting hemp, in which I was so successful last September, as will appear by the Louisville 'Journal' of that date, will claim my particular attention this year. I mention this to you lest it might appear that I had abandoned the field in Virginia by my nonappearance there in the next harvest.

$$
\begin{aligned}
& \text { "Very respectfully yours, etc., } \\
& \text { "OBED HUSSEY." }
\end{aligned}
$$

“Tree Hill, January 23d, 1844.

"Dear Sir:

"I received a few days ago your letter of the 17 th inst., on the subject of your reaping machine; you call my recollection to a trial between it and Mr. McCormick's reaper at Mr. Hutchinson's in July last, on which occasion I 'was one of a committee which gave the preference to Mr. McCormick's machine;' you also advert to a trial between these rival machines a few days subsequent, at this place, and request to know my impressions after this

Mr. Roane's Reply 
second trial. I presume from the fact of my having ordered one of your reapers for the ensuing harvest, that it is your purpose to publish this statement. Averse as I am to having my name in print on this, or any other occasion, I cannot with propriety decline a response to your inquiry. I had never seen or formed an idea of a reaping machine until I went to Hutchinson's-I was surprised and delighted with the performance of each of them, and fully resolved to own one of them by the next harvest, but their performance that day left me in a state of doubt which I should select. The report spoke in terms of high praise of each machine, and I consented to its award that on the whole Mr. McCormick's was preferable, merely because being the cheapest and requiring but two horses, it would best suit the majority of our farmers, who make small crops of wheat on weak land-for I doubted its capacity in heavy grain. After this report was made I heard your complaint that you did not have a fair trial, because being unable to bring into the field your large improved Reaper, which was up the river, you were compelled to comply with your engagement for the day, with a small and inferior machine, drawn by an indifferent and untutored team. Mr. Hutchinson's wheat was badly rusted, and therefore 
light. I had ready for the scythe a low ground field of heavy and well matured grain; partly to expedite my harvest work, and partly to renew the trial, that I might solve my doubts as to the merits of these machines, I succeeded in engaging them to be at Tree Hill on a named day. They both came agreeable to appointment, Mr. McCormick bringing the machine he used at Hutchinson's, and you bringing the one you could not on that occasion bring down the river. The day was fine, and both machines did their best, and had a very fair trial. My doubts were fully removed, and my mind convinced that for the heavy wheat we raise on our river low grounds, rich bottoms, etc., your machine is superior to Mr. McCormick's, of which I still think highly. I accordingly ordered one of yours to be made for the approaching harvest.

"I wish you all possible success in cutting hemp in the 'Great West.' It must be very desirable to cut that valuable plant instead of pulling it up by the roots, and I cannot doubt that your reaper has ample power for the process.

"Most respectfully, yours, etc., "W. H. ROANE.

"Mr. Obed Hussey, Baltimore." 
"We are not advised at what precise period subsequent to 1843 and previous to 1847 (when C. H. McCormick patented the raker's seat), that he changed the arrangement of his wheels, etc., so as to admit a seat for his raker without 'tipping up the machine' as was unavoidable previously. From evidence deemed fully reliable, he was not the first even on his own machine, to provide a seat for the raker, "and all take a ride.' It is laborious enough to test fully the endurance of the most powerful and muscular man, to ride and rake; but to walk and rake is even more barbarous than the old time ball and chain to the leg of the felon. The considerate and feeling farmer would certainly 'wait for the wagon' to be better fixed before thus undertaking to reap his grain fields if himself or his hands had to ride in this sort of style.

"We have a letter from Isaac Irvine Hite, Esq., now of Clarke County, Va., which throws some light on the subject; he says (italicised by the writer) :

"In 1842 my father, by my request, purchased for me of C. H. McCormick and Father, a reaper at $\$ 110$, which was drawn by two horses, and it was raked off to the right hand side by a man on foot. The father of C. H. McCormick stated to me at the commencement of that harvest, that it had been nine years since 
they had first operated with it, in pretty much the form it was then constructed. On a recent visit to Messrs. McCormick, who then resided on the line between Augusta and Rockbridge Counties in this State, the old gentleman stated to me that he had been at odd times at work on the reaper for many years; and either he or his son stated to me that C. H. McCormick had been improving, changing or inventing various parts until they had (as they thought) perfected the machine. * * * I disliked the labor imposed on the hand who had to walk and remove the wheat from a platform seven feet in width, and urged Messrs. McCormick to attach another contrivance so as to enable the raker to ride and perform his arduous task; the old gentleman contended that that could never be accomplished, but that a self-operating appendage could be constructed to remove the grain, but that would be uncertain, and entirely unreliable. During my visit, he pointed out to me one or more fixtures they had tried for the raker to ride on. I think one was on one wheel, and the other on two.

I yet contended that it could be accomplished; if by no other means, by changing the construction of the machine, and remarked to him, if I were a mechanic, and understood the

Mr. Hite construction of the machine well enough to a Seat venture to alter its parts, I was certain I could 
so arrange it, and requested him to urge his son to make the effort; he replied that it would be useless; that they had tried every imaginable way or plan before placing the machine before the public, and that they regarded it as an impossibility, successfully, and properly, in any other way than on foot, and said it was necessary for the heads to be brought round to the right, in which I fully agreed; but contended it could be done while the raker was riding or standing in an erect position.

After this unsatisfactory interview I returned home, and at the close of the next wheat harvest I had a small carriage, about 3 feet by $31 / 2$ feet, constructed on two wheels, and connected underneath the platform, by means of

MeCormick Condemns shafts to the back part of the head of the machine; this during the cutting of my oat crop answered every purpose, so far as the raker was concerned, but there was a difficulty in turning. C. H. McCormick came to see this combination sometime during the year, and condemned it in toto. But by the next harvest I had it so constructed, as to be drawn by an iron bar so shaped, appended and supported on the underneath part of the carriage, as to admit of the machine turning in any direction, and the carriage would follow just as the two hind wheels of a wagon do; the carriage had a seat behind, and a thick, deep cushion in 
front, for the raker to press his knees against while removing the grain from the platform to his right hand, which he was enabled to do with apparent ease with a rake of peculiar shape;-(it cannot be done with a rake of ordinary shape).

The working of the first carriage was witnessed by many gentlemen who approved of it; and the combination of the second carriage $I$ applied for a patent for. The model carriage can now be seen in the room of the Patent Office, containing models of all rejected patents. After this, I heard of McCormick making experiments at one of his Western facMcCormick Adopts Mr. Hite's Suggestion tories-I think it was at Chicago; and finally he addressed me a letter, stating he had changed the construction of his machine, and had it so constructed that the raker could ride on the machine and remove the grain."

We think the foregoing letter-for it carries truth on its face-clearly shows that the idea of "changing the construction of the machine," and permit the raker to ride, did not originate with the McCormick's father or son; for "they had tried every imaginable plan or way before placing the machine before the public, and that they regarded it as an impossibility for the wheat to be so removed regularly, successfully and properly, in any other way except on foot." 
At the trial referred to at Hutchinson's, and the late Senator Roane's in 1843, it was demonstrated that a raker could ride and rake, and as was also done by Hussey many years before, at various places, and delivering the grain at back or side. But we have still better evidence than the above-C. H. McCormick himself.

His Patent of 1847 , covering some four or five folio pages, is altogether to change "the construction of the machine," to admit of, and to patent the raker's seat; the substance of the whole is comprised within the following brief extract from the patent of 1847 :

"And the gearing which communicates motion to the crank is placed back of the driving wheel, which is therefore subject to be clogged by sand, 'dirt, straw, etc.-and in consequence

McCormick's Patent for Raker's Seat of the relative position of the various parts, the attendant is obliged to walk on the ground by the side of the machine, to rake the cut grain from the platform as it is delivered and laid there by the reel. These defects which have so much retarded the introduction into practical and general use of Reaping $\mathrm{Ma}$ chines, I have remedied by my improvements, the nature of which consists in placing the driving wheels further back than heretofore, and back of the gearing which communicates motion to the sickle, which is placed in a line back 
of the axis of the driving wheel, the connexion being formed, etc., and also bringing the driving wheel sufficiently far back to balance the frame of the machine with the raker on it, to make room for him to sit or stand on the frame," etc., etc.- "which cannot be done, if the raker walks by the side of the machine, as heretofore."

Now if C. H. McCormick's testimony in his own favor, can be considered reliable, he certainly had not invented a seat for his raker as late as 1845-and not long prior to 1847 , when he patented it; and just fourteen years after Hussey Fourteen Years Ahead Hussey had used it every year, successively. The raker's seat therefore was just as original an invention as the reel.

The "straight sickle blade," but cut one way only, and abandoned some 10 or 12 years after its conception in 1831 , as he states, appears to be the only original idea-properly belonging to whom it may-in the patent of 1834. As to the "foundation" of the machine, viz:-the platform, cog wheels, crank, etc., etc., they have been used by every projector in reaping machines, for a century.

A machine exhibited at the World's Fair in London, by C. H. McCormick, had the "straight sickle blade," but alternating the cuts every few inches. With such a machine it is impracticable to cut grain, much less grass, 
efficiently, divested of the reel. That plan has since been changed to a much more efficient blade, the scolloped edged sickle. That it was used in the Northwestern States by others several years previous to its adoption by $\mathbf{C}$. $\mathrm{H}$. McCormick, we believe admits of just as little doubt, as rests with the priority of invention of the Reel, Rakers-seat, etc.

There is one other important feature, patented in 1845 and referred to in the Pusey letter;-an "Iron case to preserve the sickles from clogging;" these we will also take a look into after a while.

Obed Hussey, as appears by the evidence before us, made his first machine in Cincinnati, Ohio, where he then resided, in the spring of 1833 , and it was patented the same year.

The Hussey Principle

His principle-the arrangement and construction of the Guards and Knives-was precisely identical with those used by him at the present day, except an improvement patented in 1847 , leaving openings at the back end of the slot in the guards for the escape of particles of straw or grass that might get in between the blades and guards.

It was communicated at the time by letter with a diagram to a personal friend now living, and of the highest respectability, from whom we have a certificate, and copy of the drawing. The knives or cutters, for lack of more suitable 
materials were made out of hand saw blades cut into suitable form, and riveted to a bar, vibrating through an opening or slot in the guards.

Judge Foster, residing within a few miles of the city, and to whom he applied, kindly offered him every facility to test the machine by cutting grain, ripe and unripe, being himself greatly interested in its success. When taken to the field, a considerable number of persons were attracted to the spot; and rather to the discomfiture of the inventor, for it may well be supposed it was an anxious moment to him, and he desired no witnesses to his failAn Early Experiment ure. The machine was started; but owing to some part giving away, or some slight defect not apparent until then, it failed to work satisfactorily. One burley fellow present picked up a cradle, and, swinging it with an air of great exultation, exclaimed, "this is the machine to cut the wheat!"

After the jeers and merriment of the crowd had somewhat subsided, the inventor remedied the defect, and assisted by the laborers present - the horses having been removed-pulled the machine to the top of an adjacent hill; when alone, he drew the machine down the hill, and through the standing grain, when it cut every head clean in its track! 
The same machine was directly afterwards exhibited before the Hamilton County Agricultural Society near Carthage, on the 2nd of July, 1833. Of its operation and success, the following statements, and certificates, now in our possession, sufficiently testify. Doctor Wallace as well as some others of the gentlemen, are living witnesses of what is here stated.

\section{Cincinnati, November 20th, 1833.}

This may certify that $I$ was present on the 2nd day of July near Carthage, in this county, at an experimental trial with a machine invented by $\mathrm{Mr}$. Obed Hussey for cutting grain. The operation was performed on a field of wheat. The machine was found to cut the Wallace wheat clean, and with great rapidity. But Testimonial owing to its having been imperfectly made, being only constructed for the experiment, some parts of wood which should have been made of iron, and in consequence frequently getting some parts out of order, a correct estimate of the quantity of work it would perform in a given time could not be made. One point was, however, satisfactorily established, that the principle upon which the machine is constructed will operate; and when well built will be an important improvement, and greatly facilitate the harvesting of grain. I would also remark that the horses moving the machine 
were walked, and trotted, and it was found to cut best with the greatest velocity.

$$
\text { C. D: WALLACE, }
$$

Secretary of the Hamilton County

Agricultural Society.

We, the undersigned, witnessed the exhibibition of Mr. O. Hussey's Machine for cutting grain alluded to by Dr. Wallace, and do fully concur with his statement of its performance. We would further add, that notwithstanding its temporary construction, its performance far exceeded our expectations. Cutting the grain Exceeded Expectations clean and rapidly, and leaving it in good order for binding. We are of the opinion that the machine is capable of being propelled at the rate of five miles the hour, and do good work. The machine was worked when the cutters were both in a sharp and a dull condition, and no difference could be perceived in its execution.

$$
\begin{aligned}
& \text { (Signed) “G. A. MAYHEW, } \\
& \text { "T. R. SEBRING, } \\
& \text { "A. CASTNER, } \\
& \text { "JACOB WHITE, } \\
& \text { "H. B. COFFIN, } \\
& \text { "C. F. COFFIN, } \\
& \text { "S. W. FOLGER, } \\
& \text { "T. B. COFFIN, } \\
& \text { "WM. PADDOCK." }
\end{aligned}
$$


There are several other certificates equally conclusive and satisfactory; but we will only copy in addition to the foregoing, a short piece from the Farmer and Mechanic, issued July $3 \mathrm{~d}, 1833$, in Cincinnati, as follows:

"Several members of the Agricultural Society on last Wednesday attended in Carthage to see a machine for cutting wheat by horse power, in operation. It was propelled by two horses, and cut as fast as eight persons could conveniently bind, doing the cutting neatly.

"This machine is the invention of $\mathrm{Mr}$. $\mathrm{O}$. Hussey, and will no doubt prove a useful addition to our agricultural implements. Mr. J. C. Ludlow suggested that it would be good economy of time and labor to take a threshing machine into the field and thresh out the grain as it is reaped, thereby saving the binding and hauling to the barn or stack. We think the suggestion a good one."

The Here, then, was the problem solved-the Problem great discovery made that had puzzled the Solved brains of hundreds if not of thousands, and for centuries. No one we fearlessly assert had ever succeeded so completely and satisfactorily, and with so simple and practical a machine.

Some visited the exhibition determined to condemn as they afterwards acknowledged, deeming the thing impracticable; but all were convinced; for the demonstration was of that 
character which left no room for doubt or cavil in the minds of any.

It was indeed a triumph,一not perhaps entirely unexpected to the inventor-but neither he, nor any one else at that early day, could foresee the wonderful changes ultimately to be effected, and the world-wide renown to be conferred on the inventor as the result of this experiment; one that was certain to immortalize his name as a pioneer and benefactor in the most useful and peaceful pursuits in life. It was too, the dawn of a brighter day to the toiling husbandman, by lightening his labors, and adding to his comfort and independence; only circumscribed in its beneficial influence by the bounds of civilization.

Some may possibly suppose that we view the invention in too glowing colors; but we have yet to meet with the farmer who owned a good reaping and mowing machine that would dispense with its advantages for twice the cost of the implement, and again be compelled to resort to the sickle, the cradle, and the scythe; for of a truth it completely supersedes all three in competent hands and with fair usage, in both the grain and grass crops.

It is difficult to confine our narrative to its intended brief limits and select from the mass of evidence on hand as to the uninterrupted success of Hussey's invaluable invention from 
that day to the present-now twenty-one years. We will therefore only select a single and short account of each year; until about 1840 or ' 42 ; not long after which a few other inventors came before the public. There was,

No however, no competitor in the field from 1833

Competitors Ontil 1841 to 1841 or 1842, either in Europe or America, so far as we can ascertain, that did more than make a few occasional trials; none attracted public attention, or were successful and efficient machines even in the estimation of the projectors themselves. The evidence proves it, and it is corroborated by our own personal knowledge, having been constantly engaged in Agricultural and Mechanical pursuits for more than thirty years-and, as we believe, familiar with most of the important improvements of the age; - of all in fact, directly connected with agriculture in its labor saving implements, of any notoriety.

Many alleged improvements have been made in the Reaper in the past ten or twelve years; and many more still within half that period. How far they are new inventions, and actual improvements, we can better judge by examining Hussey's patent; for it describes the cutting apparatus clearly and minutely, and which in fact is the whole thing,- the "one thing needful" to success. For the use of wheels, or a system of gearing to all kinds 
of motive machinery is coeval with the first dawn of mechanical science. How ancient we know not, for the Prophets of old spoke of "wheels within wheels" near three thousand years ago; and it is very certain the hand of man, unaided by wheels and machinery, never erected the vast Pyramids and other structures of antiquity. We do not believe there is a single Reaping and Mowing machine in successful operation on this continent that is not mainly indebted to Hussey's invention in the cutting apparatus, for its success: deprive them of this essential feature-disrobe them of their borrowed plumes, and their success would be like the flight of the eagle, suddenly bereft of his pinions, - he must fall; and the machines would stand still, for not a farmer in the land would use them.

As previously remarked, $O$. Hussey's first patent is dated in 1833. We omit the more general description of the machine, and copy only what embraces the most important features, the guards and knives; also an extract from his improvement patented in 1847, to obviate choking in the guards:

"On the front edge of the platform is fixed the cutting or reaping apparatus, which is constructed in the following manner: A series of iron spikes, and which I will call guards, are fixed permanently to the platform, and extend
No Reaping Machine Without Hussey Principles 
seven or eight inches, more or less, beyond the edge of the platform, parallel to each other, horizontal, and pointing forward. These The Guards guards are about three inches apart, of a suitable size, say three-quarters of an inch square, more or less, at the base, and lessening towards the points. The guards are formed of a top and bottom piece, joined at the point and near the back, being nearly parallel, and about oneeighth of an inch apart, forming a horizontal mortice or slit through the guard; these mortices being on a line with each other, form a continued range of openings or slits through the guards. The first guard is placed on the rear of the right wheel, and the last at the extreme end of the platform, and the intermediate guards at equal distances from each other, and three inches apart, more or less, from center to center.

"The cutter or saw (f) is formed of thin triangular plates of steel fastened to a straight flat rod, (g) of steel, iron or wood, one inch

The Cutter and a half wide; these steel plates are arranged side by side, forming a kind of saw with teeth three inches at the base, and four and a half inches long, more or less, sharp on both sides, and terminating nearly in a point. The saw is then passed through all the guards in the aforesaid range of mortices, the size of the mortice being suited to receive the saw with 

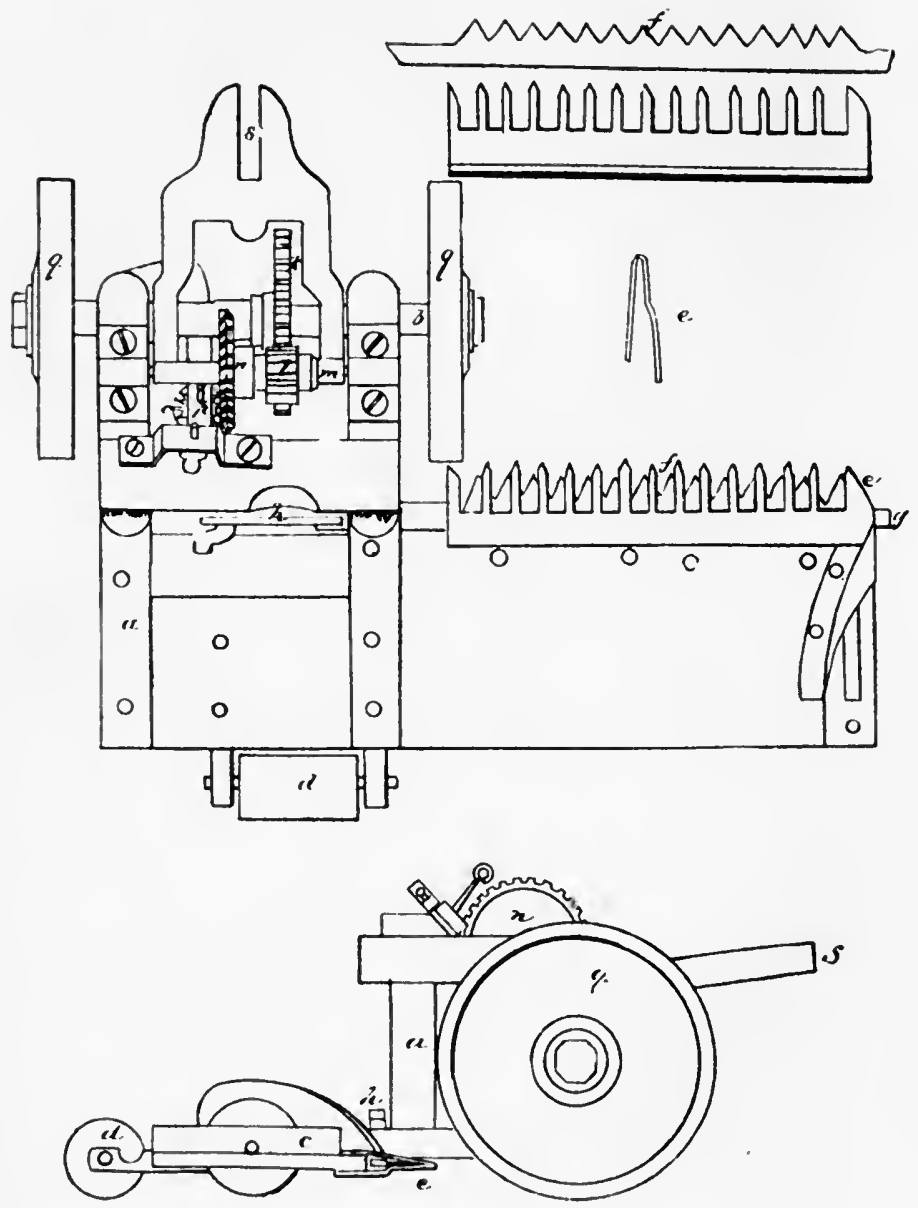

Diagram Showing Arrangement of Guards and Knives 

the teeth pointing forward; observing always that the points of the saw teeth should correspond with the center of the guards. One end of the saw is connected with a pitman moved by a crank, and receiving its motion from the main axis, by one or two sets of cog wheels. The vibration of this crank must be equal to the distances of the centers of the guards, or the points of the saw teeth, or thereabouts, so when the machine is in motion, the point of each saw tooth may pass from center to center of the guards on each side of the same tooth at every vibration of the crank; if the main wheels are three feet four inches in diameter, they should in one revolution give the crank sixteen vibrations, more or less; the saw teeth should play clear of the guards, both above and below. ***

"The power is given by locking the wheels to the main axis, the machine has one square wheel box, the other round and locked at pleasure. If the power should be wanted, one, two, or more horses are attached and driven on the stubble before the machine, the right wheel running near the standing grain, the platform with the saw in its front edge extends on the right, at right angles with the direction of the horses, with the guards and saw teeth presented to the standing grainwhen the machine moves forward, the saw 
moves with the teeth endwise and horizontal, the grain or grass is brought between the guards, the saw teeth in passing through the guards, cut the stalk while held both above and below the saw-the butts of the grain receive an impulse forward by the motion of the machine while in the act of being cut, which causes the heads of the grain to fall directly backwards on the platform-in this manner the platform receives the grain until a sufficient quantity is collected to make one or more bundles, according to the pleasure of the operator, then it is deposited with a proper instrument by the operator, who may ride on the machine."

Here follows the dimensions of a machine suited to two horses, which is only copied so far as refers to the cutting apparatus, viz: "The back of the saw may be from one inch to one and one-half inches wide, and from three-sixteenths to one-quarter of an inch thick; and the steel plates for the teeth should be about onetenth of an inch thick; one end of the mortice in the guard should be fitted to receive the back of the saw, so that the bearing may be on the back of the saw only."

"In this machine the following points are claimed as new and original: 1st. The straight horizontal saw, with the teeth sharp on their two sides for cutting grain. 2d. The guards 



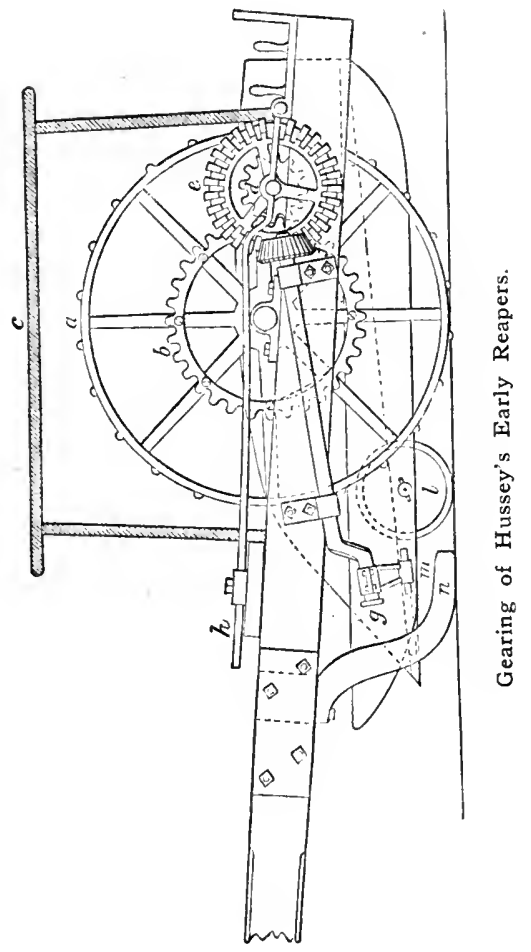


forming double bearers above and below the saw, whereby the cutting is made sure, whether The Four with a sharp or dull edge, the guards at the same time protecting the saw from rocks or stones, or other large substances it may meet with. 3d. The peculiar construction that the saw teeth may run free, whereby the necessary pressure and consequent friction of two corresponding edges cutting together, as on the principle of scissors, is entirely avoided. 4th. The peculiar arrangement by which the horses are made to go before the machine, being more natural, and greatly facilitating the use of the machine, and the general arrangement of the points as above described.

"In cutting grass, the platform is reduced in width, and the grass falls on the ground as it is cut."

In the improvement of the guards patented in 1847, the claim states: "I accordingly claim the opening above the blades A, fig. 3 , and at $D$, fig. 1 , in combination with vibrating blades. I also claim the particular application of the flush edge at the fork of the blades, for the purpose described.

"The end and design of the improvements above claimed is to prevent the blades choking."

En passant, we would ask any intelligent and candid farmer or mechanic who has ex- 
amined a successful reaper, to compare the foregoing plain specifications which all can understand, with the cutting apparatus of the most successful modern machine. And we would especially desire him to compare them in principle with the "improved form of fingers to hold up the corn, and an iron case to preserve the sickles from clogging;" not the alleged invention of 1831 , by C. H. McCormick, and abandoned from 1840 to 1843 , but the McCormick Twelve Years Late claims patented by him in 1845 [as stated in the letter to Philip Pusey, M. P.], twelve years after the date of Hussey's patent, and twelve years after his most complete and uninterrupted success in cutting both grain and grass. In fact, there was no year from and including 1833 up to 1854 , a period of 21 years the past harvest, that we have not the most positive and conclusive evidence of the success of Hussey's reaper; in numerous cases the same machines had cut from 500 to 800 , and even one thousand acres; in one instance, the same machine was used for fourteen harvests, or as many years, successively and successfully.

We have given some of the evidence for 1833. For 1834 we annex two letters giving an account of the two machines made this year, one in Illinois, and the other in New York, viz: 
"Spring Creek, Sangamon Co., Ill., "October 1st, 1854.

"Mr. Obed Hussey, Baltimore:

"Dear Sir:-Your favor of August 10th came to hand a few days since. The reason was, it lay at Berlin (formerly Island Grove Post-office) and my Post-office address is Springfield, the only place where I call for letters.

"In answer to your query, how your Reap- Canfield ing Machine worked in 1834, I have to say that Testimonial it cut about sixteen acres of wheat for me on my farm; that it did the work in first rate style; according to my best recollection, as well as any of the machines that have since been introduced. The only objection I recollect being made, was, that when the straw was wet, or there was much green grass among the wheat, the blades would choke. You certainly demonstrated in 1834 the practicability of cutting grain or grass with horse-power; and all the machines since introduced seem to have copied your machine in all its essential features.

$$
\begin{aligned}
& \text { "I am respectfully yours, } \\
& \text { "JOHN E. CANFIELD." }
\end{aligned}
$$

The next letter we copy from the Genesee Farmer of December 6th, 1834. The reader will readily perceive that the author, William 
C. Dwight, knew how to handle the pen as well as the plow, and equally well to work the reaper, being a practical farmer. But we are pained to add that he lost his life by the fatal railroad accident at Norwalk, Ct., about a year since.

From the Genesee Farmer, December 6, 1834.

"To the Editor of the Genesee Farmer:

"I wrote you last May that Mr. Hussey, the inventor of a machine for harvesting wheat, had left in this village one of his machines for the purpose of giving our farmers an opportunity to test its value, and I promised to write you further about it when it had been put to use. For many reasons which will not interest either yourself or the public, the matter has been delayed till the first rainy day, after my fall work was out of the way, should give leisure to remember and fulfill my promise.

"The machine has been fully tried, and I am gratified to be able to say that it has fully succeeded; hundreds of farmers from the different towns of this and the adjoining counties have witnessed its operations, and all have not only expressed their confidence in its success, but their gratification in the perfection of the work.

"As every inquirer asks the same series of questions, I presume your readers will have a 
like course of thought, and wish for satisfaction in the same particulars. To give them this, I will write them in their order, and give the answers :

"Does the machine make clean work?

"It saves all the grain. To use the language of a gratified looker-on, an old and experienced farmer, 'it cheats the hogs.'*

"Does the machine expedite the work?

"What the machine is capable of accomplishing, we who have used it can hardly say, as we had no field in fit order, large enough for a fair trial through a whole day; and can only say what it has done. Five acres of heavy wheat, on the Genesee flats, were harvested in two hours and a quarter.

"In what condition is the wheat left, and how is the work done where the wheat is lodged?

"The machine leaves the wheat in gavels large enough for a sheaf, and where grain stands well enough to make fair work with the cradle, it leaves the straw in as good condition to bind as the gavels of a good reaper. Whether the grain stands or is lodged is of little consequence, except as to the appearance of the sheaf, and the necessity of saving more straw, when lodged, than is desirable. The condition

* The hogs are the gleaners in this section of country. 
of the sheaf when the grain is lodged depends much upon the adroitness of the raker.

"What number of hands, and what strength of team is necessary to manage the machine advantageously?

"Two men, one to drive the team and the other to rake off the wheat, and two horses, work the machine; but when the grain is heavy, or the land mellow, a change of horses is necessary, as the gait of the horses is too rapid to admit of heavy draft. The horses go at the rate of four to five miles an hour, and when the growth of straw is not heavy a fair trot of the team is not too much.

"Is the machine liable to derangement and destruction from its own motion?

"This is a question which cannot be so directly answered as the others. We have only used the machine to cut about fifty acres, and have had no trouble; judging from appearances so far, should say it was as little subject to this evil as any machinery whatever. The wear upon the cutting part being so little as to require not more than fifteen minutes sharpening in a day; there is no loss of time on this score.

"Is the sheaf a good one to thresh?

"The man who has fed the threshing machine with the grain of twenty acres cut by this machine, says the sheaves are much better 
than those of cradled grain, and quite as good as those of a reaper.

"There is one more advantage beyond ordinary inquiries, of consequence, where so much grain is raised as in this valley; be the grain ever so ripe, there is no waste of grain by any agitation of the straw, and all the waste which can take place must arise from the handling and shaking in binding.

$$
\begin{aligned}
& \text { "I am yours, etc., } \\
& \text { "WM. C. DWIGHT. }
\end{aligned}
$$

"Moscow, Livingston Co., N. Y., Nov. 14, 1834.

"N. B.-The machine we used was intended only for upland, but by some little alterations and additions we used it with equal facility on all kinds of soil; and it can be used on any farm so clean from stumps and stones as not to endanger the blocking the wheels."

The following letter is evidence for 1835 , and also refers to the originality of the invention by $O$. Hussey.

$$
\text { "Palmyra, Mo., Aug. 14, } 1854 .
$$

"Friend Hussey-Yours duly received. As to the machines sent by you (ordered some two years since) they both worked well.

"Before you had invented your machine in 1831 or 1832 , your attention was drawn to a mode of cutting grain, hemp and grass and 
you told me you thought you could invent such a machine to be drawn by horses; and after you had returned to Cincinnati from Laurenceburg you wrote me a letter in '32 or at the furthest in '33 (for I left Indiana 2nd Oct., 1833) with a draft and description of a plan for cutting grain. The draft was thus (here follows a diagram of the cutting apparatus exactly as described by the patent) and the description was, that these knives were to work by the motion of the wheels, being a perfect description of the invented principle.

"As soon as I saw the plan, I was satisfied of its success and wrote to you that there was no doubt of the success of your machine; that it was astonishing the world had so many thousand years been confined to the sickle when so obvious a mode of cutting grain and grass existed; and shortly after you obtained a patent for the machine.

"On the 6th July, 1835, you brought to Palmyra two of your machines, and they were put in operation near this place-one in a meadow between here and Philadelphia, and one in the heavy grass in Marion City bottom.* The machines did cut well. I was the editor of the Missouri Courier, from the month of November, 1833, until 1838, and brought your ma-

- Both of these machines were sold to Wm. Muldrow, Agent, of Marion College, Marion County, Mo. 
chine before the public; it excited much attention, and its performance was highly satisfactory. The results of the trials were published in the paper by me in August or September, 1835. I knew of the capacity of the machine, and that it did so execute in the bottom three acres an hour. In this I cannot be mistaken, for I felt at the time the deepest interest in the success of the machine. Mr. McElroy is dead, where you boarded, and also Samuel Muldrow and James Muldrow. Still I will inquire if any persons can be found who were present.

"I know the results, and recollect distinctly the reception the machines met with, and the prices, to wit, $\$ 150$ each. Muldrow bought another for $\$ 500-$ which was a whirling wheel. You recollect it; it never run any. Yours, I know it was said then, would cut off brush large enough for a hoop-hole. Court is now in session, but as soon as I can ascertain the witnesses (at the exhibition) I will write you further. But my recollection is distinct, from the relations existing between us, my interest in machinery generally, and my position as editor of the only paper of this section of country.

"As ever, your friend, "EDWIN G. PRATT." 
In 18360 . Hussey visited Maryland at the written solicitation of the Board of Trustees of The Maryland Agricultural Society, for the Eastern Shore. The fame of his reaping exploits in the State of New York, and the far West, had reached the East; though with something like a "snail's pace." We had not then the Magnetic Telegraph, which with lightning speed enables the East to talk with the West; nor even the "iron horse," by whose speed and power, the reaper that cut a large crop of wheat in Maryland, could within the same week cur another equally large in the valley of the Mississippi ; but it then required some two to three years to prepare the public mind for the reception of the machine here; and owing to the Mode of limited means of the inventor, the transportaTrans. portation tion from place to place was often done by a single horse; accompanied by the inventor footsore and weary from walking hundreds of miles!

The annexed certificate was given, published, and widely circulated after a full trial of the machine, in cutting more than two hundred acres, and by large farmers and practical men, known throughout the State. Comment is unnecessary on such a paper; but we feel bound to state that it was mainly owing to the exertions of the liberal public spirited gentlemen, the last, though not the least of the sign- 
ers, Gen. Tench Tilghman, that the Reaper was then introduced into this State. He was the early and steadfast friend of the Patentee, and to the cause of agricultural improvement in our State. Strange as it may appear to many at the present day, and notwithstanding these demonstrations in Ohio, Illinois, New York, Missouri and Maryland, which did not admit of cavil or doubt as to the entire efficiency and success of Hussey's reaper, scarcely a farmer could be found ready and willing to take hold of it, and aid the inventor in introducing it into use. But farmers as a class are proverbially cautious, and disinclined to change from established customs and usages; it often requires "line upon line and precept upon precept," aided, too, by almost a free gift of the article, to induce them even to give a new agricultural implement a fair trial,-a plough, for instance, that will do better work, with a fourth to a third less draught; the old and nearly worn out implement "does well enough." Gen. T. was, we believe, the first farmer in Maryland to use and purchase a reaping machine; and by so doing, to aid the inventive genius and talent of his countrymen, and also at the same time greatly to benefit the interest of his brother farmers. It avails little to the inventor, or the public, how valuable his improvement may be,-for in nine cases out of ten the 
An inventor is limited in means,-if none can be Inventor's found who are both able and willing to lend a Difficulties helping hand to modest merit; for true genius is ever modest; and unfortunately the term is too often synonymous with penury and want.

Very few of the really valuable inventions inure to the benefit of the inventors,-even to a tithe of the profits that are occasionally realized. His necessities often compel him to a forced sale of his patent right to some capi-

The talist who has the tact to turn other men's wits Inventor's to his own advantage; or the Public,-which Rewards simply means other capitalists of another description, who possess little or no inventive genius themselves, and just about as much principle as genius-seize upon the invention, and often in spite of law, justice, or right, reap the reward justly due to another.

This, however, is a digression for which we beg the reader's pardon; but we could not let the occasion pass without rendering this honest tribute to the public spirited farmer, who had the discernment to perceive its merits, and the liberality to aid its introduction, of one of the most valuable improvements of this, or any age.

The following three letters not only embrace the year 1837, but are equally good evidence from that period to the present, 1854. As they are short, and to the point, we use 
them all. The very appropriate and just remarks of Col. Hughes as regards the rights, and what is due to inventive talent, we most cordially respond to; as must every right minded and disinterested reader. He refers to Col. Edw. Lloyd of "Wye House" as the largest wheat grower in Maryland; we much doubt if he is not the largest in the Union. Several years since, he informed us that his average crop of wheat was from 33 to 35 thousand bushels; and a year or two ago we learned that the crop exceeded forty thousand bushels. He now, and for many years past has used Hussey's Reaper exclusively. More satisfactory and conclusive evidence cannot be given, or desired, than is afforded in these three letters, of the early use, and long proved efficiency of the invention.

$$
\begin{aligned}
& \text { "Hornewood, E. Shore, Md., } \\
& \text { "August 22, '54. }
\end{aligned}
$$

"Dear Sir:-In reply to your enquiry whether I recollect the time, and the success of your reaping machine at my father's in 1837 , I answer that I do perfectly; and also seeing it in operation in company with my friend, $\mathbf{M r}$. J. H. Luckett, of Balto., at Col. H. L. Edmondson's of Talbot Co. the same season.

"My father expressed himself highly satisfied with the performance of the reaper, as did 
other gentlemen who saw it in operation at Cheston. So well convinced was my father of the value of the machine, that he offered you a considerable advance per acre on your charge for cutting, to remain and reap his two fields, say 125 to 130 acres, which you declined, owing to prior engagements. At an early date after this trial, my father secured one of your reapers, and the farm has since never been without.

"My brother, Dr. DeCourcy, has now one which did its work most excellently well this past harvest, and without any stoppage. With some trivial repairs, it has been in successful use nearly ten years.

"Wishing you every possible success with your reaper, for which the agricultural community owe you a heavy debt,

$$
\begin{gathered}
\text { "I am respectfully yours, } \\
\text { "N. H. ROZIER DE COURCEY." }
\end{gathered}
$$

"Baltimore, October 17th, 1854. "To Obed Hussey, Esq.:

"Sir-In the harvest of 1837 I saw one of your Reapers in operation in my neighborhood [West River, Anne Arundel Co., Md.] in charge of the Hon. John C. Weems, who I believe was the owner of it; and was so much pleased with its performance that I ordered one from you in the following year, 1838, which 
you set in motion for me. It worked most admirably, and fully met my expectations; as it has done from that early period to the present day.

"In a loose way, I estimated that in the saving of labor, and grain from shattering, it nearly or quite paid for itself the first harvest. Since then the machine has been much improved.

" $U p$ to the time I purchased, very few had been used in this State. The first, as I have always understood, was bought by that intelligent and enterprising farmer, Gen. Tench Tilghman, of Oxford, Talbot County. In 1838, Col. Edward Lloyd, of 'Wye,' Talbot Co., the largest wheat grower in Maryland, and myself, as above mentioned, availed ourselves of your invention; but I did not hear of any other orders for it in this State. It came, like most other agricultural implements, slowly into use; and I fear has not fairly compensated you for the labor and ingenuity bestowed upon it. This, however, is too often the fate of discoverers and inventors; and others reap the fruits of their toil and genius. I have long thought that governments were unjust to inventors; and could never understand why a man has not the same right of property to a machine conceived in his head, and constructed by his 
hands, as to that acquired in any other manner. The same that a farmer has to the lands he owns.

$$
\begin{aligned}
& \text { "Very respectfully, y'r ob't serv't, } \\
& \text { "GEO. W. HUGHES." }
\end{aligned}
$$

“Oxford, Md., Sept. 22d, 1854.

"Mr. Obed Hussey:

"Dear Sir:-I recently received from the Commissioner of Patents the Report on Mechanics for 1853, and have examined with much interest the descriptions of what claim to be improvements in the Reaping Machine.

"I was rather surprised to find that so many of then were almost identical with the notions which were tried and rejected during the season you spent with me nearly twenty years ago; when for the first time (I believe) a reaper was used throughout our entire harvest, on a farm as large as six hundred acres.

"You had just then arrived from Cincinnati with two machines-one a reaper, and the other a reaper and mower.

"They were exhibited publicly at Oxford and Easton, and their operation on wheat gave entire satisfaction. The work throughout the harvest was equally well done; the only objection being the delay caused by repairing the machinery, a difficulty common to all new machines of much power at that period. 
"Since then I have used one or more reapers every year, and have watched with much interest the progress of their improvement. I have examined most of those which have the best reputation, and do not believe there is a single one in which the cutting principle has not been copied from yours.

"In attempting to avoid an infringement of your patent, variations have been made either in the cutting apparatus, or the driving machinery, by which they have been made more complicated and less efficient. Burrall's, which approaches nearest to yours in simplicity and efficiency, is so close a copy that I do not see how the courts could refuse an injunction to prohibit the use of it. The only material difference is the attempt at a side delivery which was tried by you on your first machine, and proved an entire failure.

"Believing sincerely that the farmers of the U. S. owe you a debt of gratitude, which a regard for themselves should prompt them to pay, and understanding that attempts have The Farmers' Debt to Mr. Hussey been made to question even the priority of your invention, I send you a volume of the Genesee Farmer published in 1834, which will show the opinion entertained at that time by the farmers of that celebrated wheat growing 
region, both as to the efficiency and priority of your reaper.

\author{
"Your ob't serv't," \\ “TENCH TILGHMAN."
}

As we have already much exceeded the intended limits of the narrative, we might, perhaps, with propriety, here rest the enquiry, having, as we think, satisfactorily shown, and by evidence that cannot be disproved: first, that for a.period of nine or ten years after the Conclusive alleged invention of the reaper by C. H. McEvidence Cormick in 1831 he did not sell a single machine; nor could he establish by all the evidence adduced before the Board of Extensions, in 1848 , that prior to 1840 or 1841 was his reaper in any degree an effective or practical machine; for as he himself states in the letter to Philip Pusey, Esq., M. P., it was not until very material alterations-all essential it may be said-were made, some six or eight years after the date of the patent, could the machine be made to work even tolerably well. Indeed, he states, "I may say they were not of much practical value, until the improvements of my second patent in 1845," being eleven years after the date of the patent, and fourteen years after the alleged invention in 1831 .

On the other hand we have shown by as good and respectable testimony as can be had 
in any cause, that from 1833 to 1854 , a period of twenty-one years, Hussey's invention was most efficient and satisfactory, every year; not by cutting a patch of the fraction of an acre, but by reaping hundreds, nay thousands of acres annually, by the few machines placed in the hands of the farmers from 1833 to 1840 .

As, however, we have given no direct evidence from Delaware, or Virginia, none from North Carolina, and but one from New York, we annex a few short testimonials from each, that embrace the period from 1838 to 1845 ; and with a few more of the same respectable character up to 1853 , both in this country and in England, we will leave the decision of the question to the intelligent reader. We will, however, call the reader's attention to the concluding paragraph of Maj. J. Jones' letter, from Delaware-one of the smallest States, but containing as large a proportion of noble minded, talented men, and as good practical farmers, as any in the Union.*

It will be perceived that a reaper sold in 1838 to the St. George's and Appoquinomick

* It is reported of one of her sons, that during the struggle for Independence, when a Delegate to the Convention from one of the largest and most powerful Colonies was ready to quail and almost despair of success in the unequal contest, he was encouraged and cheered on by a member from little Delaware; and told that when he found his Colony likely to be overrun by the enemy, to call on Delaware for aid-she would lend a helping hand. 
Agricultural Society had, after subsequently coming into the possession of Col. Vandergrift, and prior to 1845, "cut about seven hundred acres of his grain," and "was then in good repair"! We wish it was in our power to state how many times seven hundred acres this single machine had reaped since 1838.

"Wheatland, Del., July 21, 1845.

"Mr. Hussey:

"Dear Sir:-I have just finished cutting my oats; I finished cutting my wheat on the 28th of June, having cut over 160 acres, excepting what was cut by a cradle in opening tracks for

An the horses and rounding the corners so that the Important Testimonial from Delaware machine might sweep round without loss of time in turning, which it did with ease and certainty, cutting more than twenty acres a day on an average. A part of the wheat was so heavy as to require three active shockers to keep up with the cutting; the whole cost of all necessary repairs $31 \mathrm{r} / 4$ cents for the harvest.

"Of the two machines which I purchased of you I used the large one, having sold the small one to Richard Millwood, who rents the farm of Dr. Noble. Strange as it may appear, I could find no landholder in the vicinity who 
had enterprise enough to risk the purchase of that machine until they could see it work; but after the performance was once witnessed, the impression it made was such as to justify me in ordering you to have ten ready by next harvest for New Castle County, Del. Mr. Millwood's wheat was very heavy, one measured acre having sixty dozen sheaves upon it, and the whole cutting time on the forty acre field was but two days, making for the small machine a full average of twenty acres per day, without any repairing or accident. None of the hands who worked it had ever seen such a machine before those you sent to me. My crop has not all passed through the half bushel yet, but it will fall but little short of 3,000 bushels

- expect it will all be in market to-morrow.

"In conversation with Col. Vandergrift, the present owner of the Reaper you sold to the St. George and Appoquinomick Agricultural Society, in 1838, he told me that he had cut about 700 acres of wheat and oats with it since he owned it, and up to that time the cost of repairs had been $\$ 1.25$ for every hundred acres cut. It was then in good repair.

$$
\text { "Yours, }
$$

"JOHN JONES." 


\section{"Jefferson County, Va., \\ "August 9th, 1845.}

"To Mr. Obed Hussey:

"Dear Sir:-We, the undersigned, having used your reaping machine during the recent harvest in cutting our respective crops, take great pleasure in tendering to you this voluntary testimonial of the very high estimation in which we hold your invention. We have now tried your machines fully and fairly, and we are unanimous in the conclusion that in every case they have borne the test in a manner which has excited our highest admiration of their merits. We were particularly pleased with their work in lodged grain; they cut and gather every straw with the utmost ease, and the only fault at all that we have had to find with them was that they did not cut wet grain with facility; this single defect, however, we are pleased to perceive you have completely remedied with the late improvement (with open guards to the knives, etc.) which the most of us saw at work in Mr. Wm. Butler's field cut wet grain and green oats as well as could possibly be desired-it will also cut timothy and clover-so that now we have no hesitation in recommending your reaper, as we hereby most cordially do, to our brother farmers, as the most complete and efficient in agri- 
cultural operations, and as one which, whilst from its simple and substantial construction, is not liable to be broken or to get out of order, will at the same time save its owner the first year more than its original cost.

$$
\begin{aligned}
& \text { "WM. BUTLER, } \\
& \text { "J. H. TAYLOR, } \\
& \text { "W. SHORTT, } \\
& \text { "JOSEPH M'MURRAN, } \\
& \text { "DANIEL G. HENKLE, } \\
& \text { "DAVID L. HENSELL, } \\
& \text { "W. G. BUTLER, } \\
& \text { "JAS. S. MARKELL, } \\
& \text { "V. M. BUTLER, } \\
& \text { "ANDREW M'INTIRE, } \\
& \text { "ADAM SMELL, } \\
& \text { "GEORGE TABB, } \\
& \text { "JOHN MARSHALL." }
\end{aligned}
$$

"Washington County, Aug. 7th, 1845.

"I hereby certify that I have used Mr. Obed Hussey's wheat cutter through the late harvest, and that it answered my fullest expectations, in every respect, except that it will not cut when the wheat is damp from rain or the dews of the morning. I cut 140 acres of wheat with it in nine days; and on one occasion, cut off thirty acres in eighteen hours, from daylight in the morning until 11 o'clock the next day, and with the same four horses, never having: changed them during that time.

$$
\text { "JOHN R. DALL. }
$$


“Oaklands (near Geneva), N. Y.

"26th August, 1845.

"Mr. Obed Hussey, Baltimore:

"Dear Sir:-Having housed all the grain crops of this farm, it is due to you that I should now frankly admit the removal of all my doubts in regard to the effectiveness and excellence of your 'Reaping Machine.' The doubts expressed in my early correspondence with you arose from the many abortive attempts in this country and in England to produce a reaping machine, possessing power and simplicity and durability; most of them were complicated, and proved too fragile.

"Soon after the arrival of your machine, I tried its power and became readily familiar with the manner of using it; the result of my experience will appear from the following facts :

"The wheat crop of this farm covered 104 acres, producing 2,540 shocks, 30,480 sheaves, as counted on the ground, and again when housed in the grain barn and sheds.

"The whole crop was cut by your reaping machine in eight days, using one team, a boy to drive and a man to manage the machine.

"The average quantity cut per day was thirteen acres. 



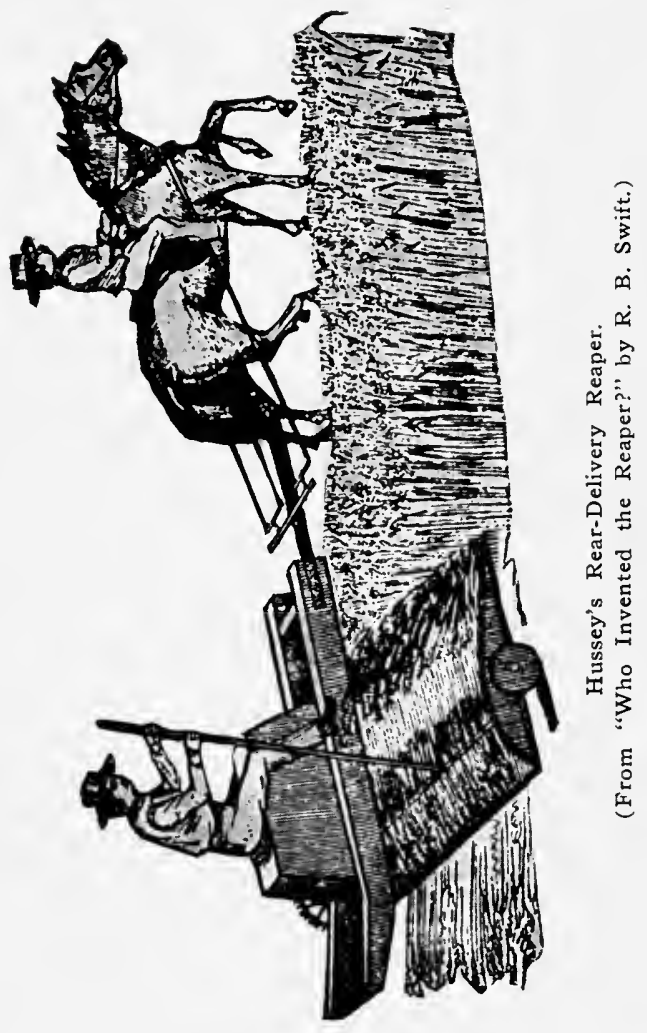


"The largest quantity cut on any one day was seventeen acres.

"The longest period for working the machine on any one day was nine hours.

"Seven men were stationed on the field to bind the sheaves.

"The cost of cutting the wheat with your machine is twenty-five cents per acre.

"The total cost for cutting, raking, binding and shocking is seventy-eight cents and a fraction per acre.

"The cost may be stated as follows, viz:

A man and team for eight days at $\$ 1.50$

per day $\ldots \ldots \ldots \ldots \ldots \ldots \ldots \ldots 12.00$

A boy to drive for eight days at fifty

cents per day.............. 4.00

Interest on cost of machine and for

wear and tear, say at 10 per cent. . 10.00

$\$ 26.00$

"Which is equal to 25 cents per acre on 104 acres. The seven men employed to rake and bind received, each, $\$ 1$ per day for eight days, say $\$ 56$, which sum added to the cost for cutting or reaping, gives a total cost of $\$ 82$, or $7888 / 100$ cents per acre.

"I have compared this cost with the cost paid by my neighboring farmers this season, and find it vastly in favor of your machine. 
The individual in this town who harvested with the most economy paid $\$ 113 / 100$ per acre-other farmers have paid from $\$ 125 / 100$ to $\$ 2$ per acre.

"Since the wheat harvest the machine has cut with signal advantage about twenty acres of oats.

"The wheat and oats were cut with such neatness and precision that the gleanings were not sufficient to pay the labor of raking.

"The machine remains in perfect order, and did not fail to perform all you promised.

"I deem it one of the best labor-saving machines ever offered for the advantage of the farmer; its effectiveness, simple and durable construction, have been witnessed with satisfaction by a large number of my neighbor farmers.

$$
\begin{aligned}
& \text { "Respectfully yours, } \\
& \text { "J. DELAFIELD." }
\end{aligned}
$$

The machine alluded to in the above letter is the low priced one at $\$ 100$.

For 1846,1847 and 1848 we copy from the Richmond Planter and American Farmerand all from North Carolina, though the evidence from other sections is much more extended, and equally as conclusive: 


\section{"Somerset Place, Washington Co., "North Carolina 25th Aug. 1847.}

"To the Editor of the American Farmer:

"Dear Sir:-Yours of the 6th ult. arrived at my residence during my absence in consequence of which I was unable to return you an answer in time for your August number of the American Farmer. I trust, however, the delay will not materially affect the value of my communication. In consequence of the recommendation of a gentleman who had used "Hussey's Reaper" in the harvest of 1846 with much satisfaction, I was induced to make a trial of one the present season. It was put in operation under the direction and supervision of $\mathbf{M r}$. Hussey himself, upon a field of reclaimed low ground, originally Cypress Swamp, which of course could only be cultivated in beds-these beds were six feet wide, including the waterfurrow between, and were intersected at intervals of about fifty yards by drains, known to us as tap-ditches, which cross the water furrows at right angles, and are cut from two to four inches deeper than the furrows themselves. I am particular in describing the land, as I had always supposed that an insuperable obstacle in the way of the regular action of any machine would be found in the irregularity of surface into which our land is necessarily 
thrown by our system of culture. The machine surmounted every anticipated difficulty, and was eminently successful, both in cutting lengthwise with the beds and across them. The wheat was cut in a most thorough manner; nothing escaped the cutting surfaces, nor did weeds or any other obstruction of the kind hinder the machine from doing its work perfectly. During the running of the machine one day in the harvest, seventeen acres of wheat were cut by it.* This was done by using relays of horses, four at each time, the same hands being employed, however, and the working time was twelve hours. After a heavy rain we were obliged to abandon the use of the machine, owing to the fact that the ground became so soft that the "road wheel" as it is termed, buried in the soil, and would become clogged with mud. This difficulty can, I have no doubt, be easily overcome by increasing the "tread" of this wheel, and making some slight alteration in the cog-wheel which gears into it.

"Some two years since I saw an experiment made upon an adjoining estate with McCormick's machine; it cut occasionally well where the wheat was free from weeds, but any ob-

*When Mr. Hussey was with me I informed him that the piece of wheat cut by the machine on this occasion equalled twenty acres, but I have since discovered that I had been mistaken in my calculation of the acre. 
struction from that source would immediately choke it, when of course the wheat would be overrun without being cut. The experiment proved a failure, and the machine was laid aside. The blade in this machine appears to me to be too delicate in its cutting surface to

\section{A}

McCormick Failure succeed, except under the most favorable circumstances. Quite a number of McCormick's have been in use in this part of the country during the last two years, and to my inquiries concerning them I have received but one answear and that an unfavorable one. The few of Hussey's machines, on the contrary, that have been employed within my ken, have in each instance given entire satisfaction. I do not hesitate to say that when well managed, with a skilful hand at the rake, in dry wheat ( $I$ do not recommend it when the straw is wet), it will, as compared with ordinary cutting, save per acre the entire expense of reaping, from the thorough manner in which every stalk is cut, thus preventing loss or waste.

"Believing, as I do, that a great desideratum to those who grow wheat upon a large scale, is to be found in Mr. Hussey's reaper, I cannot but wish that both he and they may reap the benefit of its general adoption.

"I am, sir,

"Very respectfully your ob't serv't, "JOSIAH COLLINS." 
“Edenton, N. C., January 25th, 1848.

"To the Editor of the American Farmer:

"Dear Sir:-Some months ago I received a letter from you, making enquiries of me relative to Hussey's Reaping Machine. When your letter reached me I was on the eve of leaving home for the summer, and since my return home, my engagements have been of such a character as to cause me until the present to neglect replying to it.

"I have used one of Hussey's machines one season, and though under circumstances not very favorable for the machine, I take pleasure in stating that its operation was satisfactory. During my harvest, which was about three weeks' duration, this machine was kept constantly at work, with the exception of a day and a half, yet I did not ascertain how many acres it would reap. Mr. Collins, of Lake Scuppernong also used one last season, and from him I learned that he cut upwards of twenty acres a day.

"There is certainly much less wheat left in the field by one of these machines than is by the ordinary method of reaping by the scythe or reap hook; it cuts close, lays the straw smoothly, thus rendering tying of it in sheaves much easier. 



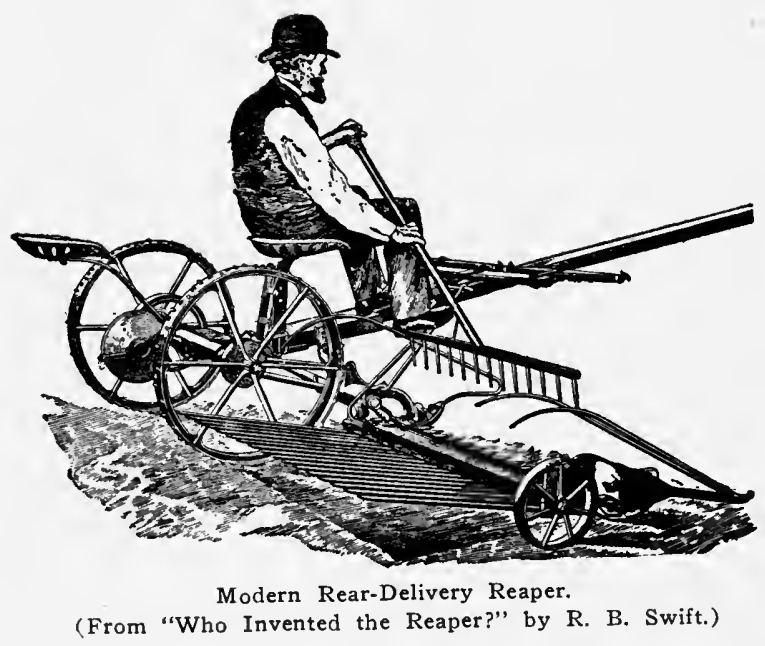


"I have witnessed McCormick's, which I consider a poor affair, and meriting no consideration except a dissent from me. Many of this last kind of reaper found their way here a few years ago; they now, or rather their remains, may be seen lying in the field whence they will never be removed.

\section{“THOS. D. WARREN."}

From the Richmond Planter.

\section{HUSSEY'S AND M'CORMICK'S REAPERS}

"It is very painful to be compelled to inflict a private injury in the discharge of a public duty; upon a particular system of cultivation we can talk and write without restraint; but when we are called on to discuss the merits of an invention, upon which the fortunes of the originator may absolutely depend, it is a much more responsible and delicate office. We are aware, too, that in introducing a subject of the kind, we are opening the floodgates of a controversy that is often hard to close; we have had the strongest evidence of that fact in the controversy that once occurred in this paper between Messrs. McCormick and Hussey, and yet it is to the relative merits of the reaping machines of these two gentlemen that we are 
compelled again to draw the public attention. Probably not less than fifteen thousand dollars has been spent in Virginia this summer for reaping machines, and it becomes a subject of great importance to the wheat growing community at least, to ascertain how such a sum is annually to be dispensed to the greatest advantage. We shall express no opinion ourself in the discussion which must necessarily follow the introduction of this subject, and we would greatly prefer that neither of the gentlemen more particularly interested in the subject would appear in our columns. We will publish statements of facts for either, provided they are made over responsible names, and are short and permanent. As one of these facts we feel bound to state that we acted this year as the agent for McCormick's machine, and we have heard great complaint of the manner in which it was gotten up; but it is but fair also to state, that we believe Mr. McCormick himself has been superintending the manufacture of his machine in the State of New York, and that probably his work has not been as well done as it would have been could he have seen to it in person. The following communication is altogether in favor of Hussey's machine: 
"I have had in operation on my plantation this year both Hussey's and McCormick's reapers. Now, as you have asked me to furnish the Planter with the result of my own experience and opinion as to the comparative merit of the two machines, it is now at your service. I have had them both in operation (as the weather would permit) for the last fortnight, and have cut with the two rather upwards of two hundred acres of wheat. Both machines have been, I think, very fairly tested in all qualities of grain, from wheat five feet and more in height, both standing up, and lodged and tangled, and averaging, as is supposed, from thirty and forty bushels, down to light, thin wheat, not averaging more than four bushels (being some galled hills) and I am candidly and decidedly of opinion that Hussey's machine is vastly superior. I deem it superior, not only in the execution of its work, but in the durability of the machine. So well pleased am I with its performance that I have ordered another machine of Hussey's for my next harvest, and also one, and probably two, for my father's plantation. I consider this machine invaluable to the grower of wheat, and would recommend every farmer who grows even fifty acres of wheat, to purchase one. He may rest assured that he will be 
pleased with his purchase. I shall probably be in Richmond shortly.

$$
\begin{aligned}
& \text { "Yours very respectfully, } \\
& \text { "T. POLLOCK BURGUYN. }
\end{aligned}
$$

"Occonichee Wigwam, near Halifax, N. C., "June 20, 1846.

"For 1849 and 1850 we will return and see how the invention progresses on the broad prairies and fertile lands of the West, where it first operated-in 1833 and 1834-and where, too, although the most luxuriant crops are grown with comparatively but little labor, it would in many cases be next to impossible to save them without the aid of this invaluable invention.

"These certificates embrace the mowing of large crops of grass as well as grain, and in addition, the cutting of more than three hundred acres of hemp in the harvest of 1849 and 1850 , by 'the same single machine.'

"Hussey's complete success in cutting grass and hemp was no new thing ten years ago; but we suppose, like the grain cutting, in the view of Philip Pusey, Esq., M. P., 'Its perfection depended on its being new only in England,' full eighteen years after it was effected in America. 


\section{"Blackberry, Kane County, Ill., "August 28, 1849.}

"This may certify that I have had one of Mr. Hussey's mowing and reaping machines on my farm this year cutting wheat, oats, and grass for a short time. I think nothing can beat it cutting timothy grass, and I intend to purchase one for that purpose. While the machine was cutting prairie grass in my field, I cut off a dry poplar stake, one inch in diameter, which had beeen sticking in the ground after it had been laid off for a ditch. I am of the opinion that it will cut wheat well, where it is so much lodged, or so foul with stiff weeds or corn stalks that it cannot be cut with any other machine I have seen in this country. Some of my neighbors say that they intend to have Mr. Hussey's reaper in preference to any other; and from what I can learn this opinion is pretty general in my neighborhood amongst those who have seen this machine work, and are acquainted with other machines. My brother farmers have had great trouble with McCormick's machine, by the breaking of sickles, and the great difficulty or rather the impossibility of getting them repaired, or getting new ones made when broken, whereas the blades of Mr. Hussey's machine can be made 
by any common blacksmith. I have no doubt but Mr. Hussey's machine will come into general use.

"D. W. ANNIS."

\title{
"Franklin Precinct, DeKalb Co., \\ "August 13, 1849.
}

"This may certify that we have seen Mr. O. Hussey's machine cut about an acre of wheat, so badly lodged that McCormick's reaper could do nothing with it, nor could it be cradled. Said Hussey's machine cut it handsomely, and laid it in very good bundles for binding.

\author{
"JOHN SCHOOMAKER, \\ "ALBERT FIELD, \\ "JOHN M. SCHOOMAKER, \\ "DANIEL MILLER, \\ "ALBERT FIELD, JR., \\ "ISAAC CRILL, \\ "JOHN MILLER."
}

\section{"Berkshire, Kane County, Ill., \\ "August 6, 1849.}

"We, the undersigned, having seen $\mathrm{Mr}$. Hussey's reaper work at cutting grass and grain, think it preferable to McCormick's or any other machine that we have seen. It cut wheat that could not be cut with McCormick's 
reaper or a cradle. We are well acquainted with McCormick's machine.

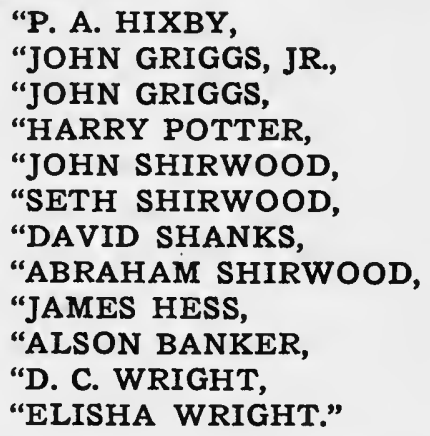

"Oswego, Ill., August 2, 1849.

"This may certify that I cut a lot of Black Sea Wheat with Mr. O. Hussey's Reaper; the wheat was so badly lodged that no McCormick Reaper or Cradle could cut it; Mr. Hussey's Reaper cut it clean and laid the bundles out of the track in good order for binding. I have seen the work done by this machine in grass; it was as good work as ever I saw done by a scythe, or better. For my choice I should rather have my grass cut by the Reaper than by the scythe. Every farmer ought to have such a machine, and every farmer I hear talk about it says the same.

\section{"PHILIP YOUNG."}




\section{"Sugar Grove, August 8, 1849.}

"This may certify that we have seen Mr. $\mathrm{O}$. Hussey's machine operate in clean grain, and where weeds were very tall, large and thick. In the former, it operated as well as any machine we have seen; in the latter, it worked to a charm, even where it was impracticable to cut with one of McCormick's Reapers.

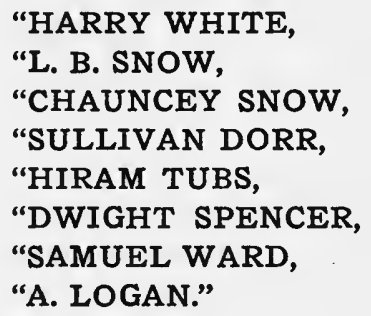

"Springfield, Ill., Dec. 25, 1850.

"Mr. Obed Hussey, Baltimore, Md.:

"Dear Sir:-I have used one of your Mowing and Reaping Machines, and consider it the best machine I ever saw, and never intend to do without one, if it is possible to get one, even if $I$ have to go to Baltimore and remain at the shop till one can be made. I do candidly believe if I had had one ten years ago I would now feel like a much younger man; and cheerfully recommend them to all who have grass 
or grain to cut, as a machine that will do their work in perfect order, neatness, and with ease to all employed.

\section{"JOHN SIMMS,}

"Four miles west of Springfield, Ill."

"Utica, Lasal Co., Ill., Dec. 14, 1850.

"Obed Hussey, Esq.:

"Dear Sir:-I received your Reaping and Mowing Machine in time for harvest, and used it for harvesting and for mowing. I am fully satisfied that your machines are the best yet offered to the farmers of this State. I have mowed about four hundred acres, a great portion of which was wild prairie, very frequently running against stones and ant heaps with sufficient force to throw both driver and raker off the machine, without injury to the machine. Why your machine is preferable to any other, is, after you have cut your different kinds of grain, fully as well as can be done with any other machine, with not over fifteen minutes' work, you can take the same machine into your meadow or on to the prairie, and cut your grass at the rate of ten acres per day, cutting closer and cleaner than can be done with a scythe. With proper care, your machines will last fifteen or twenty years, with trifling repairs.

"Respectfully yours,

"JAMES CLARK." 


\section{"Island Grove, Sangamon Co., Ill., \\ “December 25, 1850.}

"Mr. Obed Hussey, Baltimore, Md.:

"Dear Sir:-Last summer I received two of Hussey's Mowing and Reaping Machines; one from your own shop in Baltimore, and the other manufactured in this State. Unfortunately for me, I retained the one manufactured in this State, and with some difficulty succeeded in cutting about two hundred acres of wheat and grass. The one from your shop I let $\mathrm{Mr}$. John Simms have, who cut his wheat, oats and hay (about seventy-five acres) with perfect satisfaction and ease, most of it with two horses, and without being obliged to grind the knives. After Mr. Simms finished his harvest he let Mr. James D. Smith, of Island Grove, have it, who cut about three hundred acres of grass with it, the machine giving perfect satisfaction.

$$
\begin{aligned}
& \text { "Very respectfully yours, } \\
& \text { "EDWARD J. ENO." }
\end{aligned}
$$

\section{“Carrolton, Green Co., Ill., Dec. 27, 1850.}

"I procured one of Mr. Hussey's Reaping and Mowing Machines from Baltimore last spring; I cut eighty acres of wheat, and ten acres of oats, and fifty acres of timothy with it, to my entire satisfaction-after which I cut sixty acres of cloverseed with it in less than five 
days. I could not have saved the cloverseed without the machine, so I consider I saved the whole cost of the machine in the saving of the cloverseed alone.

\section{"SAMUEL THOMAS."}

"Springfield, Ill., Dec. 25, 1850.

"Mr. Obed Hussey, Baltimore, Md.:

"Dear Sir:-During the harvest of August, 1849, with one of your machines I cut sixty acres of Hemp, using a set of $41 / 2$ feet knives and guards, and two teams of four horses each, changing every two rounds, which cut on an average eight acres per day. This last harvest, the same single machine, with 6 foot guides and knives,* operated by the same force, cut successfully 250 acres of hemp, or from 10 to 12 acres per day. From this experience, I take pleasure in recommending your Cutters above the hemp cradle and hook, not only as laborsaving, by the expedition with which they cut, but as hemp saving, from the perfect thoroughness, evenness and nearness to the ground with which they do their work, and the regular and collected form in which they leave the hemp after being cut.

"Yours respectfully,

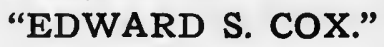

* The cutters were lengthened by removing a board that previously reduced the cutting space to $41 / 3$ feet in length. 
"Carrolton,Lebanon Co., Il1., Sept., 1850. "Mr. O. Hussey:

"The four Reaping and Mowing Machines you sent arrived safe and in good order. Their performance far exceeded our expectations, the work went on so smoothly that we scarcely knew it was hay time and harvest. '* * * If your machine had been as well known as they are now, you could have sold twenty as well as one. "Yours,

"JONAS WARD."

The few letters which follow, taken from the American Farmer, and referring to a still later period, are selected for their brevity, from many others, and principally from Maryland and Ohio. It is considered unnecessary to extend the list, for the operation and character of the machine is too well and too widely known at this day to render it necessary to the intelligent farmer and general reader, in any grain growing section of the country. $\dagger$

$\dagger$ With the view of determining as far as possible which was the best Reaping and Mowing Machines for the farmer to purchase, the Maryland State Agricultural Society in 1852 offered a prize of one hundred dollars-the largest yet offered in the country-for the best machine, to be tested by a committee appointed by the Society; a large committee of men of the first standing in the State, and all large wheat growers, was appointed, and extended notice published of the trial to take place at "Wye," the seat of Col. Edward Lloyd, Eastern Shore, Md., in July. 
"Harewood, 12mo., 8, 1852.

"Having used one of O. Hussey's Reaping and Mowing Machines during the last harvest (1852) I can state that in cutting wheat, oats and cloverseed-also in mowing my crop of grass-it has fully answered my expectations, doing the work better than I ever had it done by the scythe, and at much less expense. The machine has been tested by cutting some fifty to sixty acres of grass-quite sufficient to prove its complete adaptation to mowing as well as reaping.

\section{"EDWARD STABLER."}

\section{"Wye House, Dec. 20, 1852.}

"Dear Sir:-Having worked your Reaper for many years I have fully tested its merits. It has proved itself to be not only a wheat saving implement but a labor and time saving one - these are all important to the farmer.

"It does its work completely, regardless of the position of the wheat, if in condition to bind.

Every effort was made by the Society and Committee to give a fair and satisfactory trial; as the extent of crops in that fine wheat growing region, and extensive level face of the country, are unsurpassed anywhere for such an exhibition.

But two machines were entered for competition, McKeever's and Hussey's. The prize was awarded unanimously to Hussey. Why no others could be induced to attend was a matter of surprize at the time, and so remains with many. 
"Those you sent me in the spring worked well through the harvest, and proved their strength.

"Yours respectfully,

“EDW'D LLOYD."

“Oxford, Md., Dec. 8, 1852.

"Mr. Obed Hussey:

"Sir:-I have used your Reaper with such entire satisfaction that I am but performing a duty to my brother farmers by recommending it in the strongest terms.

"For sixteen years I have used a Reaping Machine, and know from experience that the most important qualities are strength and simplicity. In these respects your machine is superior to any other, and is the only one I have seen which can be safely entrusted to the management of ordinary overseers, with negro laborers.

"Yours, etc.,

"TENCH TILGHMAN."

"Hayes, Montgomery Co., Md.,

"December 7, 1852.

"I purchased in the year 1851 one of $\mathrm{Mr}$. Obed Hussey's Reaping Machines. I used it that year and this year in cutting my grain; I was pleased with the machine; I consider it a valuable implement, and hope never to be without one while I continue to be a farmer. My 
machine was used in cutting wheat and oatsit was not designed for grass. I employed it about half the day, and reaped about ten acres of land in grain-the rest of the day was devoted to the securing of the grain; I used four horses. My machine, I believe, was of the smallest size, and was without front wheels; with wheels it would have been a relief to the horses.

"I cannot speak of the relative value of this machine compared with others, having never seen any Reaping Machines but Hussey's at work. I do not think I could be induced to return to the old mode of cutting grain by the scythe and cradle.

"Respectfully yours, etc., "ROBERT P. DUNLOP."

"Forest Hill, King and Queens Co., Va., "December 24, 1852.

"Mr. O. Hussey:

"Sir:-It gives me pleasure to state that I used your Reaping Machine in my late harvest with great satisfaction. It fully equals my expectation as a labor-saving implement, and does the work better than can be done by the cradle. I would farther state that the seven which were purchased along with mine for my relations 
and friends of this country have given in every instance, entire satisfaction.

$$
\begin{aligned}
& \text { "Very respectfully, } \\
& \text { "WM. D. GRESHAM." }
\end{aligned}
$$

"To the Editor of the American Farmer:

"Dear Sir:-Having had a fair opportunity of observing the performance of Mr. Hussey's celebrated 'Reaper' on my farm last season, under circumstances peculiarly calculated to test its efficiency, I think it not inappropriate to bear my testimony in its favor.

"I finished cutting my grain more than a week ago. The grain was not only blown as flat as possible, but was tangled and twisted together, and lying in every direction; so much so that it would have been impossible to cut a large portion of it with the cradle. No one who saw the field believed the machine could possibly succeed.

"I take great pleasure in stating that its success was perfect and entire. It cut and gathered the grain in the very worst spots almost as well as that which was standing; and I was thus enabled to mow my crop in about one-half the time the old fashioned method would have required, thereby effecting a large pecuniary gain. It cuts the grass as evenly and as close as the most expert mower. I need 
scarcely say that I am perfectly satisfied with it. I subscribe myself yours, etc.,

\section{"AQUILLA TABOT."}

"Alexandria, Va., 12 mo., 11, 1852.

"It gives me much pleasure to state that I have had in use on my farm in Montgomery County, Md., for the past two seasons, one of 'Hussey's Reapers,' and its operation has given me entire satisfaction in every respect. It appears to combine the three qualities so important to the farmer, efficiency, durability and economy. I can, with great sincerity, recommend its general adoption.

"BENJAMIN HALLOWELL.

"To Obed Hussey:

"Dear Sir :-Having used one of your Reapers upon land, a great deal of which was hilly, stony and rough, I take pleasure in saying that it has given entire satisfaction, and proved to be a very durable, well built, and great labor saving machine.

$$
\begin{aligned}
& \text { "Respectfully, } \\
& \text { "A. B. DAVIS." }
\end{aligned}
$$

“Greenwood, Mont. Co., Md., Dec. 20, 1852."

“Pickaway County, O., July 1, 1851.

"I made an experiment this season in my field of testing the McCormick and Hussey Reapers. I tried each fairly and under similar 
circumstances. I am satisfied that Hussey's is decidedly the best Reaper, both as to cutting grain and durability. The objections made to Hussey's Reaper by agents and manufacturers of other machines I do not find, upon trial, to exist in any one particular.

"WM. STAGE."

"We, the undersigned, present at the trial, concur in Mr. Stage's statement: $Z$. Pritchett, John Reber, Philip Stuart, Isaac Stage, John Hogeland, Michael Eyer."

"Salem Tp., Champaign Co., O., July, 1851.

"I have worked with McCormick and Hussey's Reapers three seasons, and unqualifiedly pronounce Hussey's the best machine. It cuts cleaner and faster, and leaves the grain in better order on the ground; and this is the opinion of every hand in giving an expression of the comparative merits of the two machines.

"THOS. OUTRAM."

"Union Township, Champaign County, O.,

$$
\text { "July, } 1851 .
$$

"I have for the past four seasons worked Hussey's Reaper, and unhesitatingly pronounce it vastly superior to McCormick's or any other Reaper I have seen used.

"WILLIAM T. ZOMBRO." 
"Salem Township, Champaign County, O.,

$$
\text { "July, } 1851 .
$$

"I have had Hussey's Reaper used on my farm. It will cut 20 acres of the heaviest wheat per day, with ease. I consider it far superior to the McCormick Reaper.

$$
\begin{aligned}
& \text { "JOSHUA BUFFINGTON." } \\
& \text { "Ross County, Ohio, July, } 1851 .
\end{aligned}
$$

"I have used Hussey's Reaper, and consider it an invaluable machine. I have seen McCormick's Reaper operate, and am of opinion that Hussey's is the best machine.

$$
\text { "D. M'CONNELL." }
$$

"Union Township, Champaign County, O.,

$$
\text { "August, } 1851 .
$$

"I have used Hussey's Reaper for four years. I prefer it to every other machine. I do not have to drive fast, and the raking is the easiest work in the field.

\section{"JOHN EARSOM."}

"Salem Township, Champaign County, O.,

$$
\text { "August, } 1851 .
$$

"I bought a Hussey Reaper this season, and it has given the best satisfaction. I cut wheat that was down as badly as any I ever saw. It operated well by driving in a slow walk. My hands would rather rake than bind.

"JOHN LEE." 
"Union Township, Champaign County, O.,

$$
\text { "July, } 1851 .
$$

"I have used for five years Hussey's Reaper. It is a labor and grain saving machine. It is a much better machine than McCormick's, in several particulars; it is more substantial, not so liable to injury, and will cut faster and cleaner. I cut this season, with three horses, sixteen acres of heavy wheat, in five hours and thirty minutes.

\section{"REZIN C. WILSON."}

\section{“Bergen, September 1, 1851.}

"This is to certify that I have for three seasons used one of Hussey's Reaping Machines, which I purchased at the Genesee Seed Store, and that it gives perfect satisfaction. I have cut my wheat when it was very badly lodged, much faster, better and cheaper than it could have been done in any other way. I had one of McCormick's, but left it in the road, a useless article, as I consider it, having tried for three years to use it without success.

"I consider Hussey's machine just the thing for our farmers, and I could not now, after having proved its merits, be induced to be without one.

\section{"NOAH WILSON."}

With a few general remarks as to the reputation of Reaping Machines in England, and 
on the authority of the annexed English publications, we take leave of the subject.

At the trial for which the "Great Council Medal" was awarded, but which no practical farmer in this country would consider as any trial at all, being merely the attempt to cut a small space in green and wet grain, and during the temporary absence of Hussey, his machine was operated by ignorant laborers of the "Chrystal Palace," and who had never before seen a reaping machine.

This did not satisfy the English farmers; complaints were soon heard of injustice, partiality, and unfairness. It compelled C. H. McCormick or his agents to offer a challenge, which was promptly accepted by Hussey; and before the Cleveland Agricultural Society a tolerably fair trial was had of the rival machines, though neither the grain nor ground was then in a suitable state. For the decision of twelve prominent men and practical farmers we refer. to the annexed English account for the complete triumph of the unmedalled machine.

In an interview with an extensive agricultural implement maker of Yorkshire-himself an inventor of many valuable implements, and to no small extent a rival-he spoke of Obed Hussey as a man who conferred honor on his own country; as well by his genius and 
talents, as by his integrity of character. This feeling was alike honorable to the gentleman who gave it expression, and just to an American citizen.

Obed Hussey is perhaps the only American who ever waved the "Stars and Stripes" on the soil of England [placed there, too, at different

Mr. times, on his machine, by Englishmen] or who Hussey's could do it without a strong feeling of envy Distinction and jealousy being engendered. Even Englishmen, jealous as they are known to be, viewed Hussey as a public benefactor, and his mission as one calculated either directly or indirectly to benefit all classes. Yet in his own country, which he has so signally benefited, he is compelled to supplicate for years, and as yet in vain, for rights, that others, with not a tithe of his claim and merit, but with more ample means perhaps, or more influential friends, succeed in obtaining. It is a reproach to the age and to the Halls of Legislation. When it was supposed this great invention was perfected in England, many years ago-though not successful, as was subsequently provedthe Nation took the matter in hand, and Parliament voted a reward to its author.

At the great Agricultural Exhibition for "Bath and the West of England," held at Plymouth in 1853, the Plymouth Mail states: ["the interest and excitement created by the 



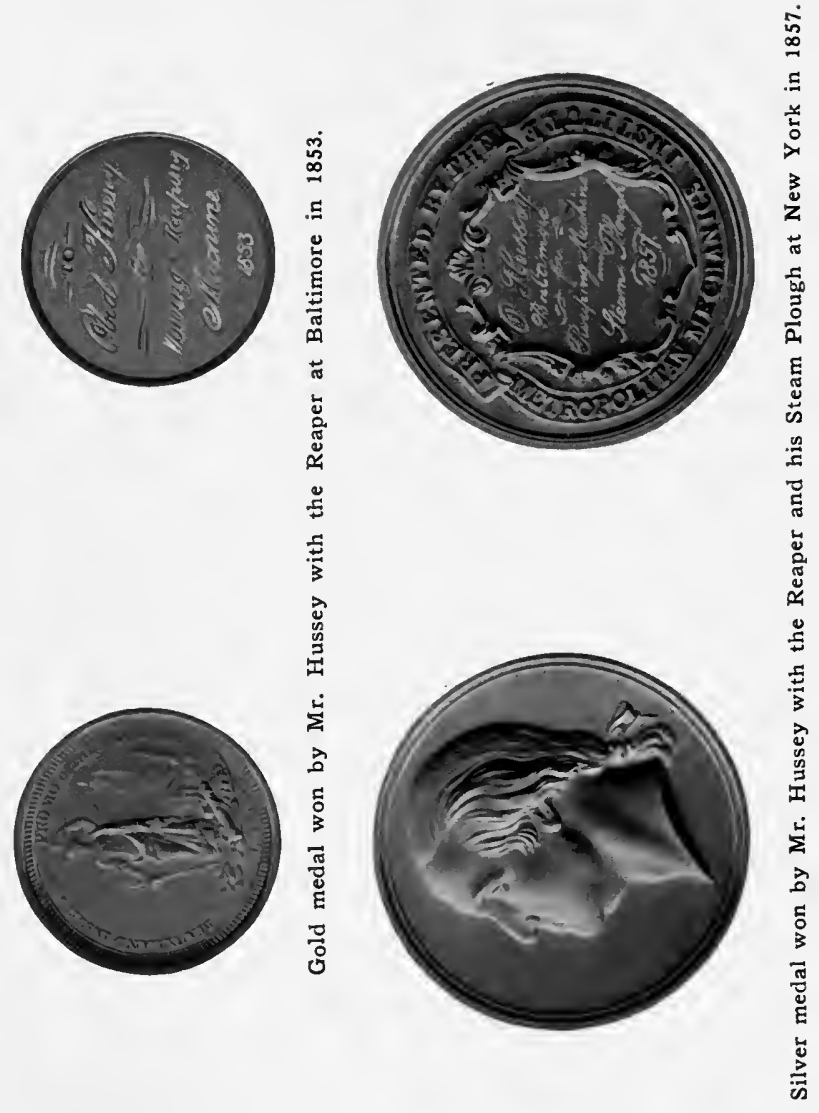


trial of Reaping Machines was very great, and the crowd of persons assembled to witness their performance was immense"] - that Hussey won the prize for Reaping, by acclamation, over all competitors-the only other American machine present, McCormick's included; and an eye witness states that three cheers were proposed for Mr. Hussey by Sir Thomas Ackland, the President, and member of Parliament, which was responded to by thousands, and without a dissenting voice; that his reaper was crowned with laurel by the Judges, and the "Stars and Stripes" waved in triumph twentyfive feet high over American ingenuity and enterprise on English soil.

At this trial it was again demonstrated to the agriculturists of Great Britain by Obed Hussey [and not the first time, though he was the first to do it] that his machine would cut their grass quite as perfectly as their "corn." The Mail goes on to say: "A mowing machine was so remote from the expectations and hopes of the Society, that no prize was offered for one; yet Mr. Hussey was prepared with a mowing machine, which was taken to an adjoining field of meadow grass and clover mixed. The people followed, but evidently with no expectation of being gratified. The machine mower was put in action, and to the admiration of every one, it cut the grass with an evenness and

A Mowing Machine as Well as a Reaper 
precision which is truly surprising, being more close and even than a scythe. The grass left behind the machine was quite evenly spread, and where it was not so, it lay so light and open that the use of the tending machine was scarcely necessary. The admiration of the truly astonishing performance was universal.

"The cutting the rye was looked for, but mowing the grass took every one by surprise. Thus a great desideratum has been achieved; the farmer has now only to gear up his horses and take a ride through his meadow, and his grass is cut."

Again, at the Royal Agricultural Society's Exhibition, held at Lincoln, the present season, the Mark Lane Express states that Hussey's machine won the prize over all competitors; and admits that Bell's machine was "at last fairly beaten."

Is there an American who can read these accounts who does not feel indebted to the man who, solely by his own perseverance and skill, has added lustre to his country's renown in the peaceful walks of life? If the same man, as a "warrior in hostile array," had raised the same flag in triumph on the same soil, how would his countrymen have rewarded him? Doubtless by a "vote of thanks by both Houses of Congress," together with a sword and gold medal, if not a monument in addition! 
Should not those be equally honored and rewarded by the Country, who are engaged in the arts and in agriculture; who devote their energies to add to the comfort and happiness of their fellow man, as those engaged in shedding blood, making widows and orphans to mourn for their untimely bereavement, and who literally for hire, not patriotism, and with the spirit demons, seek to slay and destroy?

We fully believe so; for fame and renown in arms are rarely or never acquired, except by entailing misery and distress on our fellow beings, and engendering the worst feelings and passions of our nature.

But we hope for the advent of better days; when, if the political sword is not literally beaten into a plough-share, and the partisan spear turned into a pruning hook, the inventive genius and talent of our countrymen shall be more aided and better rewarded by Government, in its praiseworthy efforts "for the diffusion of knowledge among men," in all that really ennobles the mind, and benefits the whole human family. Such, at least, is the. earnest wish and desire of

\section{A FARMER AND MECHANIC.}




\section{HUSSEY'S REAPING AND MOW. ING MACHINE IN ENGLAND}

"In presenting the following pages for consideration of the farmers of the country, the subscriber has confined himself strictly to matters selected from English papers, which will speak for itself. As a short explanation from me will be looked for, I will merely state that at the trial in presence of the Exhibition Jury, An Unfair Mr. McCormick's machine was operated by an Dis- experienced hand sent from the United States, advantage while mine was managed by English laborers of the lower class, who were total strangers to it, and had never seen it in operation. The trial was made in unripe wheat on a rainy day. My machine was very improperly adjusted for the work and wrongly put together, in consequence of which the ignorant raker failed to deliver the sheaves, and it stopped as a matter of course, and was immediately laid aside, after cutting but a few feet. My machine was never tried in presence of that Jury by any other hands, or in any other condition, myself not being in England.

"It was on such a trial that the Exhibition medal was disposed of, and with what justice the reader can judge by reading the following pages. On my arrival in England I took my 


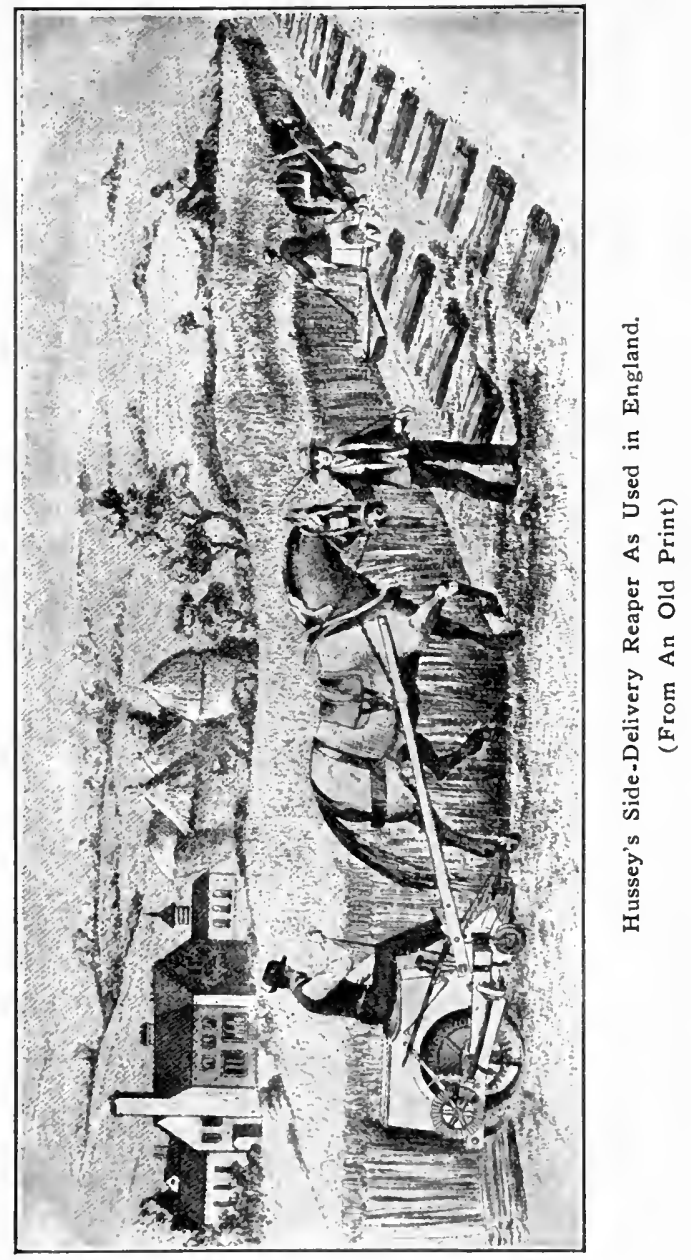



machine into the field that it might work its way into public favor as it best could. After being exhibited in several places, its rising fame appeared to produce some effect, as it will appear by the following in the Windsor and Eaton Express of November 8, 1851 :

"Alluding to the astonishing and unexpected performance of my Reaper, it says: ' $B y$ this unlooked for turn of events, the proprietors of McCormick's machine found that their supremacy was no longer undisputed, and that the necessity was laid upon them to look to their laurels; they therefore came boldly forward, and threw down the gauntlet!'

"That farmers who are acquainted with my reaper may understand why it failed to perform well in the hands of strangers at the Exhibition trial where McCormick got the medal, it will be necessary for me to say that when the machine was sent from Baltimore it was set to cut high. That when the inexperienced hands undertook to make it cut low, they pitched down the cutters by putting on the tongue, not knowing any other way to lower it. In doing so the hind part of the platform was of course raised high. In this condition the unpracticed raker failed to push the heavy wet wheat off up an inclined plane; and as a matter of course the machine choaked, and for the same reason that a mill will choak when the

How McCormick Received a Medal 
corn goes in faster than the meal comes out. A skillful hand would have lowered the cut at the axle of the machine, and brought the platform horizontal or lowest at the rear, as it should be in cutting wet grain.

"The following pages will show the result, the authenticity of which, if doubted, will be proved by the production of the originals in my possession.

"OBED HUSSEY.

"Baltimore, Md., Jan. 1, 1852."

From the Hull [England] Advertiser, September 5, 1851.

"At the annual meeting on Mr. Mechi's Farm at Tiptree Heath, a few weeks ago, a brief report of which appeared in the Hull Advertiser at the time, several reaping machines were tested, the result then being that one manufactured and invented by Mr. McCormick, of America, was the only one which was considered to have done its work properly. Amongst those tried was one invented and manufactured by Mr. O. Hussey, Baltimore, Md. (U. S.) which, in the opinion of gentlemen then present, did not fully accomplish the object in view. It should, however, be mentioned, that while Mr. McCormick's machine had on that trial the advantage of the superintendence of persons intimately acquainted with its mechanism, and who had been accustomed 
to the working of the machine for some years, Mr. Hussey's invention was (in the absence of the inventor) in the hands of persons entirely unacquainted with the proper mode of working it. Since then Mr. Hussey himself has come over to England in order to superintend his machine, and the result has been that it is now brought out to receive a thorough trial of its merits.

"The trial of Wednesday, however, was the best. It took place in a field belonging to Mr. Coskill, Grovehill Lane, Beverly. There was assembled during the day a great number of farmers and gentlemen interested in agriculture, who witnessed the trial with great interest.

"The wheat in this case was very much 'laid;' indeed in many places it was almost flat on the ground. It therefore afforded one of the best opportunities for judging of the capabilities of the machine under disadvantageous circumstances that could possibly occur.

"On the whole, the conclusion come to was that the reaping was done as well by machine as by hand. No one doubted for a moment that it would cut corn well where it was standing; but some farmers thought it would not equal the scythe where the corn was laid. The result, however, showed the contrary, and every person acknowledged that it had suc- 
ceeded admirably. After cutting a large quantity of wheat, the machine was taken into another field, and after a slight alteration, set to work to cut clover. We understand that on the day before previous to coming to Hull, it had been tried on clover and cut it extremely well.

Winning Its Own Way

"As the machine cut along it was followed closely by groups of farmers striving hard to find flaws in its performance. But they could not. On the contrary, in those places where the corn was most 'laid,' and where, consequently, the greatest difficulty must occur in the cutting, the manner in which the reaper did its work elicited their loudest approbation. 'Why,' said one burly old gentleman by our side, 'a man with a scythe could never cut it like that.' 'It is wonderful,' said another.

From the Morning Advertiser, September 12, 1851.

"On Monday last, the public trial of Hussey's patent Reaping Machine took place with the permission of his Grace, the Duke of Marlborough, on his Grace's estate of Blenheim, near Woodstock, Oxfordshire, and also, on the adjoining one of $\mathrm{Mr}$. Southern, one of the most considerable landed proprietors of the country. A large assemblage of the Agriculturists of the highest class attracted by the celebrity which this ingenious and efficient contrivance has ac- 
quired for itself in a course of successful experiments performed last week in Yorkshire, were present to witness the trial, mostly from Oxfordshire and the adjoining counties, but many from a considerable distance, and all of them concurred in the most ready acknowledgments of its advantages.

"The reaping commenced at 11 o'clock in the barley field, the machine being drawn by two fine chestnut horses, lent by his Grace for the purpose of the experiment, in which he took the deepest interest, following the reaper in a car, and watching with evident satisfaction, the ease and rapidity with which the blades cut down the golden produce of the field. The crop was by no means one calculated to favor the experiment. On the contrary, some The Duke of Marlborough's of it was down and much laid. It was cut down, however, with great regularity and speed, and the general evenness of the stubble was the subject of general remark. As the machine passed on, hewing its way at a smart pace through the dense mass of stalks, the crowd of eager observers rushed after it, and many were the cheers with which it was welcomed. Occasionally, to satisfy the ideas of the more fastidious, the level of the cutters was changed, so as to leave a greater or less length 
of stubble, and it was evident to all that in this respect the machine was susceptible of the nicest adjustment. Some times at the end of a turn it was rested to give the farmers an opportunity of inspecting it, which they seemed never tired of doing, and then it was turned round at right angles to cut in the cross direction. In the experiments upon barley, it showed itself capable of reaping the enormous space of fifteen acres, which we believe is from eight to nine times the power of the most vigorous and skillful reaper. Afterwards the machine was taken into a large field of clover, which it cut to within two inches of the ground, and with still greater rapidity.

"His Grace repeatedly expressed his admiration of the powers of the apparatus, and congratulated some of the agricultural gentlemen present with him on the prospects of greater economy and security in harvesting which it afforded them. These opinions were generally entertained upon the ground, and yesterday at Bishop's Startford, in Hartfordshire, the farmers of that part of the country witnessed a similar experiment, attended with results precisely similar, and which gave them the same satisfaction." 



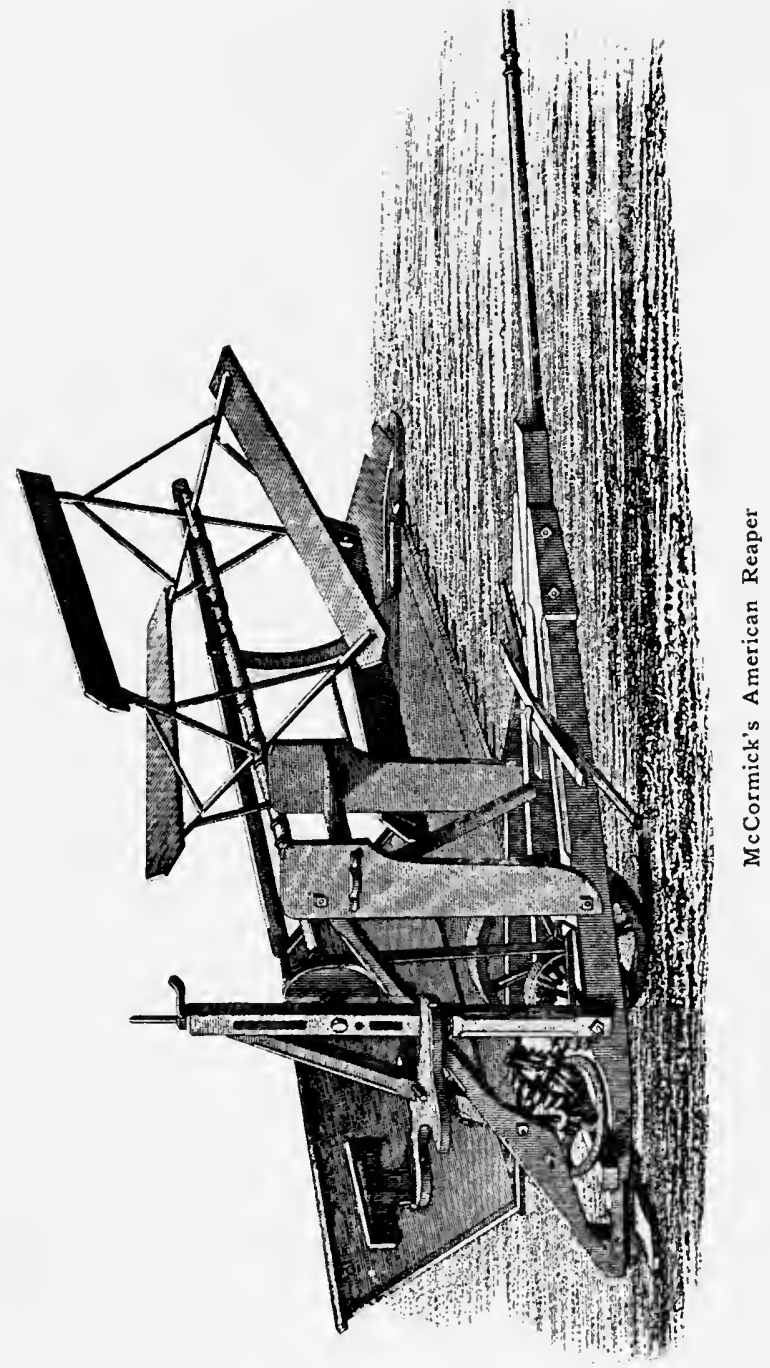


The following testimonial was given by the Duke of Marlborough:

"Tuesday, September 9th, 1851.

"Having yesterday witnessed the working of the American Reaping Machine, patented by Mr. Hussey, and being requested to give my opinion upon its execution, I state that it performed its work admirably, laying the corn when cut very neatly for tying up, and leaving the stubble very regular.

\section{"MARLBOROUGH."}

Following upon these various successes, an advertisement from the proprietors of McCormick's Machine appeared in the public papers, as follows:

\section{MR. M'CORMICK'S AMERICAN REAPER}

"Public Challenge to Makers and Venders of Reaping Machines: We, the undersigned, agents for Mr. McCormick, having observed sundry advertisements and circulars complain- The ing of the decision of the Jurors of the Great Challenge Exhibition of 1851 in favor of Mr. McCormick's Reaper, and of the reports given in the public journals of the trials which led to such decision, do hereby give notice to Messrs. Wm. Dray \& Co., Messrs. Garrett \& Son, Mr. O. 
Hussey, and all other makers and venders of Reaping Machines whatsoever, that M'CORMICK'S REAPER will be tried at the Cleveland Society's Show at Marton, Middlesbrough, near Stockton-on-Tees, on the 25th inst., and publicly CHALLENGE them or any of them, to meet us there, with their machines, for the purpose of a comparative trial of the respective merits of each, to be determined by the Chairman and Council of the Cleveland Society, or by such Judge or Judges as the said Society may appoint. BURGESS \& KEY, 103 Newgate Street, London."

The Challenge was immediately accepted.

\section{MR. HUSSEY'S AMERICAN REAPER}

"In answer to an advertisement which appeared in the Times of the 18th, from Messrs. Burgess \& Key, giving us a PUBLIC CHALLENGE to a TRIAL of the AMERICAN

The REAPING MACHINES, we hereby announce Acceptance that we shall willingly ACCEPT the SAME, and on the 25th inst. we shall be prepared at the Cleveland Society's Show, Marton, Middlesborough, near Stockton-on-Tees, to prove to the Agricultural World the superiority of HUSSEY'S REAPER for general farming purposes. We stipulate, however, that the $\mathrm{Ma}$ - 
As no report was made of the trial on the first day, the following may be relied upon:

From the Gateshead Observer, September 27, 1851.

"It was curious to see on the soil of a Cleveland farm two implements of agriculture lying side by side in rivalry, respectively marked, 'McCormick, inventor, Chicago, Illinois,' 'Hussey, inventor, Baltimore, Maryland'-America competing with America, on English soil.

"Mr. Hussey led off. An attempt was made to keep back the eager crowd; but their curiosity was irrepressible; they flocked in upon the machine so that the experiment could not be properly performed, nor could the jury duly discharge their duties. P. C. Thompson did his very best; he was all but everywhere at once; but what avails a police force, one strong, against a concourse of Yorkshire yeomanry and clowns? It was requisite that he should have recruits, and a body of self-elected 'specials' came to his aid, who succeeded in procuring approach to a clear course. Mr. Hussey then took his seat anew, and his machine cut down a breadth of wheat from end to end of the field. It seemed to us to do its work neatly and well. The wheat was cleverly delivered from the teeth of the reaper, and handed over to the binders by the rake." 
"Stockton-on-Tees, September 27th, 1851.

"Sir-Having been in communication with you relative to the trial of your Reaper against McCormick's, and feeling deeply interested in the introduction of the new implement into this district, particularly one of so much importance as a Reaping Machine, I think it is not probably out of place in me if I give you the result of my observations during the two trials which have taken place. From the fact that McCormick's Machine obtained the prize at the Great Exhibition (though I do not pin my faith upon awards made by Agricultural and other societies) the letter of Mr. Pusey's, in the Royal Agricultural Society's Journal, the various newspaper reports, etc., etc., it was natural for me to be predisposed in favor of McCormick's Machine; indeed Mr. M. had a prestige in his favor, which of course operated against the 'Little Hussey.' Previous to starting, at Marton, on Thursday, the gentlemen representing McCormick's machine expressed themselves desirous of testing the machines early in the morning when the dew was on, believing that their machine would cut the grain under such circumstances, and that yours would not. Well, on Thursday we had a deluge rain, the surface of the land was very soft, and 
chines shall be tested, not only on a particular patch of good upstanding grain, where they might, perhaps, prove equal, but on an average variety of conditions, as to short and laid corn, etc., such as the farmer will usually meet with. Its capabilities for cutting green crops, such as clover, etc., shall also be proved. It must be evident to the Farming Public that the Reaping Machine which will cut a crop of the greatest variety and difference of condition must possess the greatest merit. WM. DRAY \& CO., Agricultural Warehouse, Swan-Lane, London Bridge."

Accordingly the matter was arranged, and the following gentlemen were called upon to act as jurors:

Henry Stephen Thompson, Esq., of Moat Hall, Foreman; Mr. Wm. Lister of Dunsa Bank; Mr. Jno. Booth of Killerby; Mr. John Parrington, of Brancepeth; Mr. Wm. Wetherell, of Kirkbridge, Darlington; Mr. Robert Hymers, of Marton; Mr. Christopher Cobson, Linthorpe; Mr. Robert Fawcitt, of Ormsby; Mr. Joseph Parrington, of Cross Beck; Mr. John Outhwaite, of Bainesse; Mr. Geo. Reed, Hutton Lowcross; Mr. Thomas Phillips, of Helmsley, and Mr. Thomas Outhwaite, of Bainesse. 
The following were the conditions to be submitted by the representatives of the respective machines:

The machines to be tried on wheat and barley in such order, and for such lengths of time, as the jurymen may direct. The jury to have full power to use any means they deem advisable in order to put the machines to the severest trial. The jury in deciding on the merits of the two machines, to take into their consideration:

Conditions 1st. Which of the two cuts corn in the best of the manner.

Contest

2d. Which of the two causes the least waste.

3d. Which of the two does the most work in a given time.

4th. Which of the two leaves the corn in the best order for gathering and binding.

5th. Which of the two is the best adapted for the ridge and furrow.

6th. Which of the two is the least liable to get out of order.

7th. Which of the two at first cost is least price.

8th. Which of the two requires the least amount of horse labor.

9th. Which of the two requires the least amount of manual labor. 
day been fine the number of spectators present yesterday (Thursday) would have been at least fourfold what it was. Bad as the weather was, not only was there a large muster of members of the society, but 803 persons, many of them from a considerable distance, paid sixpence each for admission to the ground. The trial of the rival machines was, unfortunately, so short, and conducted under such adverse circumstances, that it was impossible to pronounce any opinion as to their relative merits; but what he saw of Hussey's was as satisfactory as he could expect. (Applause.)

"Mr. George Reade, of Hutton Lowcross, said, had it not been for the boisterous weather, the receipts of the Society at Ormesby and Middlesbrough would have been marvelous. As it was, there was a large assemblage to witness the trial of the American reaping machines, and they were regarded with an anxious desire that they might succeed. Indeed, let any ingenious mechanic-he cared not whether he was English, Scotch, Irish, American or German-come before a jury of the farmers of Cleveland with an implement or machine for the improvement of Agriculture, and it would be judged with candor, impartiality and uprightness, and the inventor should go home satisfied that he had experienced fair play. (Applause.) 
"Mr. Isaac Wilson proposed the health of 'The Strangers.' To those gentlemen the members were greatly indebted for their attendance. Had the weather permitted, they would all have experienced much pleasure from an inspection of the celebrated reaping machines in action, and the ingenious draining plough of Mr. Fowler, which did him very much credit. (The toast was drank with musical honors.)

"Mr. Pierce, the representative of Dray \& Co., being called upon to respond, rose and said, bad as the weather had been, he had been delighted with his visit to Middlesbrough. The kindness of the inhabitants soon made him no stranger. He was not four and twenty hours in the place before he fraternized with the whole parish. (Laughter.) He rejoiced that Mr. Hussey's reaping machine was now in the hands of a jury of Cleveland farmers. It would have a fair, honest, impartial trial; and what more could an Englishman desire. (Applause.) He thanked the company for the honor which they had conferred upon their visitors from a distance, and wished continued success to their flourishing society. (Applause.)

Mr. Hussey's

Toast to England

"Mr. Hussey was next called upon, and said that he had for many years been building machines in America. If he had had the least idea of the interest which England would take in the reaping of crops by machinery, it would 
the corn very wet. Everybody there was astonished to see your machine brought up the field at a trot, cutting its way to the admiration of all present; it not only cut to the leaning corn, but it cut cross over the corn leaning to the left of the postillion (I presume I must call him). McCormick's machine then attempted to start (he made two or three attempts) but the attendant confessed it was impossible to do so. That there might be no mistake about it, your representatives proposed that their machines should go up again; the jury said 'No! we are satisfied that your machine can cut it under the present circumstances,' and so ended Thursday's trial."

From the Gateshead Observer, October 4.

"We left the members and friends of this society, on Friday, the 26th ult, on the Showground at Middlesbrough, immersed in rain. The scene now shifts to the Townhall, where, in a handsome and spacious apartment, we find them assembled in the evening, to dinner, to the number of 150, with the Earl of Zetland in the chair, and in the vice-chair Mr. John Vaughan, of the firm of Bolckow \& Vaughan, iron-masters and manufacturers. His lordship was supported by the Rev. W. F. Wharton, of Birmingham, and Messrs. J. T. Wharton, Henry Pease, G. D. Trotter, Isaac Wilson, 
George Coates, J. W. Pease, George Reade, John Pierson, etc.; and the vice-chair by Messrs. C. Dryden, W. Fallows, R. Chilton, etc. In the body of the hall were the leading inhabitants of the town and neighborhood; also, Mr. Burgess and Mr. Samuelson (who had come to the meeting with Mr. McCormick's reaping machine), Mr. Hussey, the inventor of the reaper which bears his name, and $\mathrm{Mr}$. Pierce and Mr. Stevens (on the part of Messrs. Dray \& Co., agents for Mr. Hussey).

"On the removal of the cloth, the noble Chairman (behind whose seat was inscribed on the wall in conspicuous characters, 'Success to the Cleveland Agricultural Society-Eighteenth Anniversary') gave the customary loyal toasts, and took occasion to observe that had it not been for the Exhibition of Industry, projected by Prince Albert, the 'Reaping Machine,' from which he anticipated great benefits to agriculture, would not have been introduced into this country. (Applause.)

"The Earl of Zetland again referred to the reaping machine. Such an aid to agriculture, his lordship observed, was needed in Cleveland and elsewhere.

"Mr. J. T. Wharton, of Skelton Castle, said he had never witnessed so much enthusiasm in an agricultural district as was displayed in connection with the reaping machine. Had the 
mick's machine. The other was in the hands of the inventor himself, Mr. Hussey, and of Mr. Pierce and Mr. Steevens (who represented the agents, Messrs. Dray \& Co.)

"The Rev. Mr. Wharton (the jury, competitors, etc., having gathered round him on the field, on Saturday morning) announced that after the lapse of an hour, when the corn would be in such a condition that Mr. Fawcitt, as he had just said, would, under ordinary circumstances, reap it himself, the trial would commence.

"The question was, now, which of the two machines should begin. A 'toss' gave the chance to $\mathrm{Mr}$. Pierce, and he requested Mr. Burgess to lead off.

"McCormick's machine then got into action, taking the crop in the most favorable manner -that is, leaning toward the knife. Passing along the field (which was from two to three hundred yards in length) it cut down a breadth of little more than four feet. The corn being laid, the flier, of course did not come into practical operation; nor was it necessary that it should do so-the elements having already done its work. The corn was well cut-the stubble a little too high.

"Another breadth or two having been cut, Hussey's machine followed, and cut some 
breadths-somewhat wider than McCormick's, and closer to the ground.

"Mackenzie, when we pointed out the shorter stubble of his rival, admitted the fact, but said there would be no difficulty-not the slightest-in bringing Mr. McCormick's knife nearer to the ground. In America, however, where the straw is comparatively of little or no value, the stubble is no object, and there are some advantages in cutting high.

"A backer of McCormick's machine (and many bets have been laid on the two machines) urged that Hussey's would spoil clover when going among wheat. The reply was, that Hussey's knife could be raised or depressed at pleasure.

"The next test was cutting the crop across ridge and furrow, so that the corn was lying neither to nor from the knife, but sidewise. Both the machines cut the corn under these circumstances-Hussey's the cleaner of the two.

"The jury then required the experiment to be made along the field, with the corn lying from the knife.

"Mr. Hussey consented, and the machine succeeded in cutting the corn-leaving a tolerable stubble, but not so short and regular as before. 
have been a difficult thing to keep him on the other side of the Atlantic; and he knew not, now, after the reception which he had met with, how he should ever get home again. (Applause and laughter.)

"Mr. Steevens, Dray \& Co.'s engineer, was also called upon to rise, and stated that his employers had purchased Mr. Hussey's machine because they saw it to be the best, and they would meet every competitor in the three kingdoms, fearless of the result. (Cheers.)

"[It should be stated that Messrs. Fowler, Burgess, Samuelson,* etc., had by this time left the hall, and therefore could not be called upon.]

"Mr. Parrington, having read the award, announced that a second trial of McCormick's and Hussey's reaping machines would be made, if the weather were favorable, on the following morning (Saturday), at 9 o'clock, at Mr. Fawcitt's farm. The jury, appointed by the committee, would give no opinion on the trial of the previous day (Thursday). That would go for nothing. They would devote the whole of next day, if necessary, to a full, fair, and satisfactory trial of the two machines. (Applause.)

"On Saturday morning, the weather was so far favorable that there was no rain. The trial,

* McCormick's agents. 
therefore, took place. There was a numerous gathering of land-owners, farmers, laborers, etc., but not so crowded a muster as to obstruct the experiment.

"The foreman of the jury, Mr. Thompson, being unavoidably absent, his place was supplied by the Rev. W. F. Wharton, of Birmingham. Messrs. Lister, Outhwaite, (J. and T. P.) Booth, Wetherell, Phillips, and Dobson, were also absent. Their places were filled by Mr. William Morley, Dishforth; Mr. Thomas Parrington, Marton; Mr. J. T. Wharton, Shelton Castle; Mr. Wm. Hill, Staunton; Mr. Joseph Coulson, Sexhow; Mr. Joseph Harrison, White House; Mr. John Mason Hopper, Marton.

"The trial commenced in a level enclosure, adjoining the road from Stockton and Middlesbrough to Ormesby Hall (the residence of Sir Wm. Pennyman, Bart.). The wheat was laid. We have seen a crop in worse condition, but not often. The straw was damp and soft. The soil was loamy and light, and the field free from wet; it was to Mr. Fawcitt's credit that he was able to place such a field at the service of the society under the circumstances; still, the earth was in a state to clog the wheels of the reapers. Altogether, the test was a severe one for the competitors. Mr. Samuelson, Mr. Burgess, and Mr. D. C. Mackenzie (the son of an emigrant from Ivernesse) were in charge of Mr. McCor- 
he would soon beat the inventor himself. Even $I$, townsman as I am, made fair work; and in an hour or two's practice, I would engage to cut a crop in a manner not to be found fault with. You may safely say that any ordinary workman about a farm would be able to manage the machine; and when I say this of Hussey's, it is also true of McCormick's. The one may be a better machine than the other, but the merits of either of them may be brought into practical action by a laborer of average intelligence and skill. It is the opinion of farmers and others with whom I have conversed, that the saving per acre, by the use of Hussey's machine, would be about $5 \mathrm{~s}$.

"At the close of the contest on Saturday, the knives of the two machines were placed in the hands of Mr. Robinson, engineer to $\mathrm{Mr}$. Bellerby, of York, that he might report thereon, and on the machinery generally, to the Jury. "Wednesday, October 1.-The Marquis of Londonderry, and several other gentlemen, have visited Mr. Fawcitt's farm, to see the machine at work.

"The laurels so recently placed upon the brow of Mr. McCormick have been plucked off-not wholly, but in great part-by his fellow countryman, Mr. Hussey.

"We would enlarge upon this theme, but our report has left us little room. We would 
only say, that while the farmers of Cleveland, and of the Island generally, are turning their attention to agricultural improvements-by reaping machines, draining ploughs, and steam ploughs-we would say to them, in the words of Mr. Hussey to the Cleveland horse-jockey, when his machine was ready for its work, 'Now, then, go ahead!'"

\section{REPORT OF THE JURY}

"The Jury regret exceedingly the most unfavorable state of the weather on the days of trial (a perfect hurricane raging during the whole of the first day), and their consequent inability to make so full and satisfactory a trial as they could have wished.

"The machines were tested on a crop of wheat, computed at 25 bushels per acre, very short in the straw, and if possible, more laid than the wheat.

"The Jury, taking the different points submitted to their consideration, in the order as mentioned :

"1. Their unanimous opinion, that Mr. Hussey's machine, as exhibited by Messrs. Wm. Dray \& Co., cut the corn in the best manner, especially across ridge and furrow, and when the machine was working in the direction of the corn laid. 
"McCormick's machine was then tried, and failed. As it scoured over the corn, making sad havoc, there were loud cries of 'Stop! stop! you're wasting it!'

"Barley was next cut, with much the same result. In this case, Mr. Hussey adjusted his platform for discharging the corn at the side.

"The binders being summoned before the jury, and asked which of the two machines they Hussey Wins 6 to 4 preferred, so far as their particular department was concerned, decided, 4 for McCormick's, 6 for Hussey's.

"Clover was now to be tried, but at this stage of the proceedings we left the field. Clover-cutting, we should state, formed no part of the competition. The agreement merely refers to wheat and barley. McCormick's machine is not intended for clover-cutting; but some of the land owners and farmers were anxious to see clover cut by Hussey's machine. Mr. Thompson, we understand, had requested his proxy to have the experiment made. We were told on the ground that the machine had already been tried on clover at Newport, near Middlesbrough, and 'cut it well-if the weather had been dry it would have cut it beautifully.'

"It was pleasant to mark the anxiety and watchfulness of the gentlemen in charge of the two machines. Mr. McCormick suffered no loss from his absence, he was so admirably rep- 
resented; and in Messrs. Pierce and Steevens, Dray \& Co. had invaluable agents-on the Thursday in particular, when a storm, which ravaged land and sea, could not deter them or Mr. Hussey, from practically attesting the reaper's prowess in the field. The trial, throughout, was conducted with a fidelity to self which would not throw a point away, and a courtesy to rivals which should ever mark honorable competition.

\section{From a Correspondent.}

"Stockton, Monday, September 29.-A report reached me, after I left the farm, that Hussey's machine cut the barley very much better than McCormick's. It came to me, however, through parties who might fairly be suspected of a bias, and therefore I kept my judgment in suspense until I could obtain information on which I could more implicitly rely. This I have now got. I have been to the farm again today, and made inquiries of persons who saw the completion of the trial. McCormick's machine did not cut the barley so well as Hussey's. It cut it much too high; and as the crop was very much laid, the heads only, in many cases were cut off. We had Hussey's machine in operation to-day, both on barley and wheat, and made better work than on Saturday. Mr. Fawcitt worked it with the greatest ease. I think 
"2. By a majority of eleven to one, that Mr. Hussey's machine caused the least waste.

"3. Taking the breadth of the two machines into consideration, that of Mr. Hussey did most work.

"4. That Mr. Hussey's machine leaves the cut corn in the best order for gathering and binding. This question was submitted to the laborers employed on the occasion, and decided by them, as above, by a majority of 6 to 4 .

"5. Their unanimous opinion that $\mathrm{Mr}$. Hussey's machine is best adapted for ridge and furrow.

"6. This question was referred by the Jury to Mr. Robinson, foreman to Messrs. Bellerby, of York, a practical mechanic of acknowledged ability, whose report is appended below.

"7. That Mr. Hussey's machine at first cost is less price.

"8, 9. The Jury decline to express a decided opinion on these points in consequence of the state of the weather.

"The trials took place on the farm of Robert Fawcitt, of Ormsby, near Marlbro'-on-Tees, who in the most liberal and disinterested spirit allowed his crops to be trodden down and damaged to a very great extent, especially on the 25th, when in spite of the storm an immense crowd assembled to witness the trials. 
"The Jury cannot conclude their report without expressing the great pleasure they have derived from seeing two machines brought into competition that were able to do such very good work, and also at witnessing the friendly, straightforward, and honorable way in which the exhibitors of the respective machines met on this occasion.

"Signed on behalf of the Jury, "W. F. WHARTON, Foreman."

MR. ROBINSON'S REPORT ON QUESTION 6.

"Having carefully examined both machines, and given the subject due consideration, I am of opinion that McCormick's Reaping Machine, as at present made, is most liable to get out of order.

"(Signed) THOMAS ROBINSON.

"York, 30th September, 1851."

From the London Mercantile Journal.

"The Great Exhibition and Transatlantic Superiority Over European IngenuityAmerican Reaping Machines.-The close of the Crystal Palace has given rise to many panegyrics, and we would not for one moment detract from its merits; it has been deservedly the admiration of the world, and visited by thousands of its inhabitants. Brought into life by 
the most eminent men, and supported by royalty; the means taken were such as no private individual could have accomplished; every exertion was used to obtain the choicest relics that the earth could produce; almost every country vied in exhibiting the arts and treasures of its products and manufactures, and were with one exception considered eminently successful. The United States of America, however, was thought to be deficient, and in one or two cases some rather strong and even coarse remarks were indulged in. But what are the results? France can boast of the richness of its silks and artificial manufactures, and England of its machinery; but we find that our own newspapers are filled with admiration at the inventions of Brother Jonathan. We shall only slightly touch upon the sensation produced by the splendid performance of the American yacht, and the dexterity displayed in the lock-picking, which was previously deemed impracticable. But it may be said that these are trifling matters in a national point of view; still, facts have been elicited by these apparent trifling incidents, for we find that the superior build of the little American yacht involves a principle-it being now admitted that in nautical matters the Americans are equal, if not superior, to other nations in their construction of their merchant vessels, and also in the equip- 
ment of their ships of war. On the land they are equally successful; their reaping machines have astonished our agriculturists. We extract from the Gateshead Observer, and other local papers, the surprising performance of Hussey's and McCormick's machines. Our readers are aware that there are two rival parties competing their powers on British ground, and without entering into the question as to which of the two performed their work in the best manner, we copy the result of the trial. The Durham Advertiser states that the performance took place at Middlesbro', and says :

" 'Few subjects have created a greater sensation in the agricultural world than the recent introduction into the country of the reaping machines of Mr. McCormick, and the subsequent appearance, of a rival, of no inferior description, in a similar implement from Mr. Hussey. The interesting trial of the two in competition, intended to have taken place on Thursday last, was postponed, in consequence of the torrents of rain, until Saturday, when, under the superintendence of a very efficient jury empanelled to decide the respective merits of the two implements, the contest came off. The compact form of Hussey's implement was in its favor, though from the notoriety of McCormick's at Mr. Mechi's farm, the general preference was at first on his side. McCormick's ma- 
chine was first tried against the inclination of the corn, and completed its portion in very good style, leaving the sheaves in a handy manner at the side of the furrow. Hussey's completed a similar breadth, but deposited the sheaves behind, and consequently several binders were required to follow the machine to clear the course for cutting the next breadth, an imperfection, which, however, it was understood could be easily remedied, and the back deliver replaced by a side one. This breadth was closer cut than the one executed by McCormick's reaper. The two were then tried across the ridge, where Hussey's implement carried the palm, McCormick's leaving a very considerable portion of the straw standing behind it; and the last trial upon the wheat, in the direction of the lean of the wheat, Hussey's machine did its work very fairly, while McCormick's was obliged to be stopped in its course, after having taken the heads of the wheat, but left the whole of the straw standing. At this time two opinions did not exist among the company present-Hussey's being the favorite. The trial was then carried to some barley, where Hussey's again succeeded in obtaining public favor. The more compact form of Hussey's implement, as well as the superiority of the clipping action over the cutting action of McCormick's, entitle it to a greater share of public favor, and as the 
advantages of a side delivery can be easily applied to it, it will doubtless become the more general in use amongst the farmers. We cannot, however, but think that some mechanical process might be substituted for raking the sheaf from the receiving board, and this with a few other mechanical improvements, would we think, make Hussey's reaping machine a perfect, useful and economical agricultural implement. The latter may be also advantageously applied to the cutting of clover crops, which is quite out of the question with the farmer. Another Correspondent on this subject says:

19 Out of 20

Favored the Hussey Reaper

"The jury did not on Saturday announce their decision, nor have they yet made a report. Nineteen farmers out of twenty who witnessed the trial were in favor of Hussey's machine." "The Gateshead Observer remarks: "The great Cleveland contest between the two American reaping machines, respectively invented by Mr. McCormick, of Chicago, and Mr. Hussey, of Baltimore, originally appointed for Thursday, the 25 th ult., frustrated, for a time by the deluge and hurricane of that disastrous day, came off on Saturday, the 27th. The trial was one of great severity, the crops of wheat and barley were laid, and the straw damp and soft. The laurels so recently placed upon the brow of Mr. McCormick have been plucked off-not wholly, but in great part, by his fellow coun- 
tryman, Mr. Hussey. Both the machines proved their ability to do good work, but Mr. Hussey's attested its superiority; and the English farmer has now seen, thanks to Prince Albert and the Exhibition of Works of Industry, that his corn and grasses, hitherto slowly and laboriously reaped with the sickle and the scythe, may now be plained off the land, in five feet breadth, as rapidly, as a horse can trot." "

" A trial has taken place before the Cleveland Agricultural Society of the respective merits of McCormick's and Hussey's American Reaping Machines, and the report of the jury of practical men, appointed by the consent of both parties to decide the question of merit is favorable to the latter implement. This decision throws considerable doubt upon the justice of the award of a great medal at the exhibition to McCormick's.'-London Times, October 7."

Following upon its success at Cleveland, the proprietors were invited to exhibit the machine at the Barnard Castle Agricultural Society, Lord Harry Vane, president.

"Barnard Castle, October 8, 1851.

“The undersigned President, Vice Presidents, and members of the Barnard Castle Agricultural Society and others who have wit- 
nessed the working of the American Reaping Machine, invented by Mr. Hussey, do certify their unqualified approval of its operations and entire success.

"Lord Harry Vane, President.

"W. F. Wharton, Vice President.

"John Mitchell, V. P., Forcett Hall, Yorkshire, Esq.

"J. S. Edgar, M. D., Barnard Castle, Esq.

"John Dickonson Holmes, Barnard Castle, Solicitor.

"George P. Harrison, Forcett, Yorkshire, Esq., Farmer.

"Edward Scaith, Keverston, near Darlington, Esq., Farmer, and Assistant Draining Commissioner.

"Thomas Robinson, Hutton Hall, near Richmond, Yorkshire, Esq., Farmer.

"Richard Kay, Forcett Valley, near Darlington, Esq., Farmer.

"William Harrison, Greta Bridge, Yorkshire, Esq., Farmer.

"Thomas Carter, Scales, near Richmond, Esq., Farmer.

"Jno Whitfield, London, Esq.

"Rev. Thomas Boys Croome, Scotland. "William Watson, Jr., Barnard Castle, Solicitor.

"J. R. Monkhouse, Barnard Castle, Manufacturer. 
"Samuel Nelson, of Scaife House, near Staindrop, Durham, Esq., Farmer.

"William Thompson, Lanehead, near Ovington, Yorkshire, Esq., Farmer.

"John Ethwaite, Bainesse, near Catterick, Yorkshire, Farmer.

"Rev. George Dugard, Barnard Castle, Incumbent of Yorkshire, Farmer.

"William Watson, Secretary of the Barnard Agricultural Association."

From the Darlington and Stockton [England] Times, October 11.

BARNARD CASTLE AGRICULTURAL SOCIETY.

MR. HUSSEY'S REAPING MACHINE.

"Great interest was excited in Barnardcastle and its neighborhood on Tuesday last, by the announcement that $\mathrm{Mr}$. Hussey's reaping machine would be exhibited at the forthcoming meeting of the Barnardcastle Agricultural Society; and that a trial of its powers would be made previous to the meeting. Accordingly, on Tuesday last, the machine was brought into operation in a field of barley, belonging to $\mathrm{Mr}$. George White, of Stainton, near Barnardcastle, which it cut admirably well. The Rev. W. F. Wharton, and other gentlemen in the vicinity, besides a vast number of farmers, were present. The Judges on the occasion were $H$. S. Thompson, Esq., of Moat Hall (one of the Agricul- 
tural Jury of the Great Exhibition); W. Lister, Esq., of Dunsa Bank; and T. Robinson, Esq., of Hutton. Luncheon was provided for a large party in an out-building near the scene of the experiments, and it is a fact worthy of notice that after dinner Mr. Thompson proposed the health of Mr. Hussey (who was present) with great fervour, and spoke of the disadvantages under which Mr. Hussey's Machine had labored when tried against McCormick's for the Great Exhibition Medal; Mr. Hussey not being in the country at that time, and no one being present who understood the adjusting or working of the implement. Mr. Thompson said he was now so thoroughly satisfied of its great merits that he would do his best to get a medal awarded to it. After luncheon, the machine was taken to the grounds of Mr. Adamson, and tried upon a field of oats, which were so laid as to form a very severe test to the machine, but it nevertheless was successful there also. The party retired greatly pleased with it, and some of the most wary agriculturists ordered machines upon the ground. On Wednesday morning a large assemblage of agriculturists met on the farm of Mr. F. Atkinson, Westwood, Startforth, to see the machine cut a field of wheat, and there again the experiment yielded all that even its inventor could desire. We understand that a large number of orders were 
given for machines by the farmers present, which is perhaps the very best test of their views in the matter. The general impression seemed to be that it would prove of incalculable value to the agricultural interest.

"At about 3 o'clock in the afternoon, a large party sat down to a sumptuous dinner at the King's Head Inn. Lord Harry Vane presided and the Rev. W. F. Wharton occupied the vicechair. After dinner the usual loyal toasts having been proposed, the vice-chair proposed the health of Mr. Hussey; that gentleman, he said, had contributed to their gratification and interest in bringing his invention there for trial; the result of that trial had exceeded everything they could have previously imagined or hoped; and therefore he begged they would excuse him for proposing this health so early, as Mr. Hussey and his agents's representative, Mr. Pierce, had to leave by the first train from Darlington, which they had then but sufficient time to reach. He proposed the healths of $\mathrm{Mr}$. Hussey and of the enterprising firm, Messrs. Dray \& Co., who had undertaken to bring that machine into the British market. The toast was drank with honors. Mr. Hussey briefly returned thanks.

"After some further proceedings, the ViceChairman proposed the health of the President. Lord Harry Vane responded.

\section{A Toast to Mr. Hussey}


"The healths of the Vice-Presidents were proposed. Mr. Mitchell briefly responded. Mr. Wharton, in acknowledging the toast, took the opportunity of again bringing before the meeting the merits of the invention which had been the object of that day's attraction. It had been most unfortunate that when the trial took place for the prize of the great exhibition, $\mathbf{M r}$. Hussey had not arrived in this country-nobody knew how it was managed, whilst McCormick's was properly attended to. Mr. Hussey's machine did no work, and Mr. McCormick took the medal. No sooner did Mr. Hussey arrive than he prayed for a further trial, but the Jury could not grant it. All difficulty was removed by $\mathrm{Mr}$. McCormick throwing down the gauntlet. The trial came off in Cleveland-the result was clear and satisfactory in favor of Mr. Hussey's machine as decidedly superior. Mr. Thompson, of Moat Hall, one of the Great Exhibition Jury, was "A Worthy, also one of the Judges in Cleveland, and was Modest and so satisfied on the subject that he left, deterUnassuming mined to urge for a medal for Mr. Hussey. It must be a source of pleasure to all to find that justice was thus about to be done to a worthy, modest and unassuming man." 
From the Darlington and Stockton Times, October 11, 1851.

THE REAPING MACHINES AT BARNARDCASTLE.

"To the Editor of the Darlington and Stockton Times:

"Sir-I beg to trouble you with a few particulars of Mr. Hussey's American Reaping Machine, which I yesterday saw working in a field near Barnardcastle. I am not a farmer, and of course cannot be thoroughly au fait at describing an agricultural implement, nor am I sufficiently versed in mechanics to explain to you the construction of the machine in all its details, but of the result I can speak, and that with confidence.

"Drawn by two horses, a man seated on the near side horse as driver, this wonderful implement was drawn with perfect ease, at more than the rate of three miles an hour, round and round a field, partly in wheat and partly in barley, cutting a breadth of corn in its progress with a regularity and evenness that was surprising. No straggling stalks of corn were left, none of the slovenly irregular work too often seen where manual labor is employed was to be discovered; on the contrary, the field after shearing, looked nearly as smooth and even as a kitchen floor or turnpike road. The farmer has now no longer occasion to be behind the 
reapers, dinning in their ears, 'shear low'-'now do shear low;' for this machine, with a very simple adjustment, will cut the corn as low as he can possibly require. A seat on the machine is provided for a man, who, with a large rake, and with motion resembling the pushing of a punt, removes the corn from the machine as it is cut, and leaves it for the binders to put together in sheafs.

"The assistance of two men and two horses are thus all that is required to draw and to guide this wonderful sickle—and so manned, it will cut with the ease and regularity I have described, from perhaps ten to twelve acres in the working day. Nor as far as I could see, or learn from the observation of others, does there appear to be any drawback against its general adoption. Its price (£21) is not exorbitantits construction is not so complex as to cause a fear of frequent repairs being required; men of the common run of agricultural laborers are quite competent to go with it, and the work of drawing it is not distressing to the horses. Neither does the nature of the ground appear to be much an object, for it traveled as well over ridge and furrow as it did upon a level.

"Nothing could be more unanimous than the approval of which the machine met with from all who saw its work, and I was informed that nine machines were ordered on the 
ground. Among the purchasers was the Duke of Cleveland, who, with Lord Harry Vane, was present and examined its working and construction minutely. The curiosity excited by the machine was great, and an immense number of people visited the ground during the two days. Noblemen and gentlemen, farmers and farm laborers, tradesmen and mechanics, men and women, flocked to see the implement which from the other side of the Atlantic has come to effect so important a revolution in the labor of the harvest field, and all were agreed that Brother Jonathan, though still a young man, had some clever notions in his head, and that John Bull, in the case of the reaping machine, would not be above taking advantage of his intelligence. I am, etc.,

$$
\text { "A. B." }
$$

From the London Daily News.

HUSSEY'S REAPING MACHINE-TRIAL BEFORE PRINCE ALBERT.

"The celebrated battle of the Ganges hardly excited more interest in the railway world than the battle of the Reaping machines has lately created in the agricultural world; nor is the result perhaps very much less important in the latter case than in the former.

"Of the recent inventions for diminishing the cost of production, the most remarkable are 
undoubtedly the Reaping machines of Messrs. Hussey and McCormick. Perhaps it would be more accurate to call them importations than inventions, since both have been in use for a considerable time in America; and amongst the benefits arising from the Exhibition, it is certainly not the least that it has introduced to the agriculturist of Great Britain implements of the highest practical utility, which might otherwise have remained forever exclusively in the hands of their brethren across the Atlantic. It will be remembered that a trial of the two rival machines took place last summer, at $\mathrm{Mr}$. Mechi's model farm in Essex, having been directed by the royal commissioners, with the view of determining the comparative merits of the two instruments, whose patentees were competitors for the forthcoming medal prizes. At that time Mr. Hussey, the American inventor of the machine called after his name, had not arrived in the country. The weather, too, was very unpropitious for the trial, notwithstanding which a very large number of gentlemen were present. The machines were tried upon a field of wheat, and the result was such as to convince all present of the superiority, in every point of view, of McCormick's machinea conviction which was subsequently confirmed by the fact of the Exhibition medal being awarded exclusively to the patentee of 



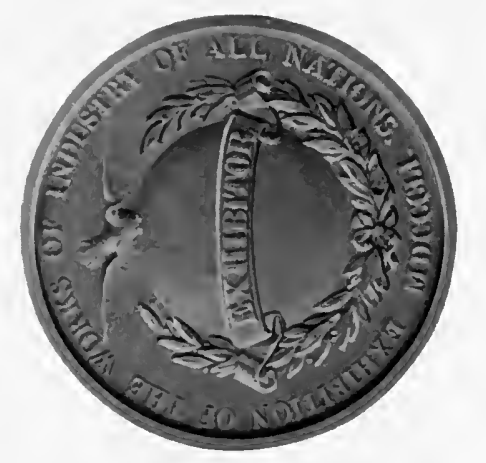

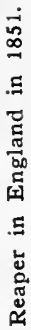

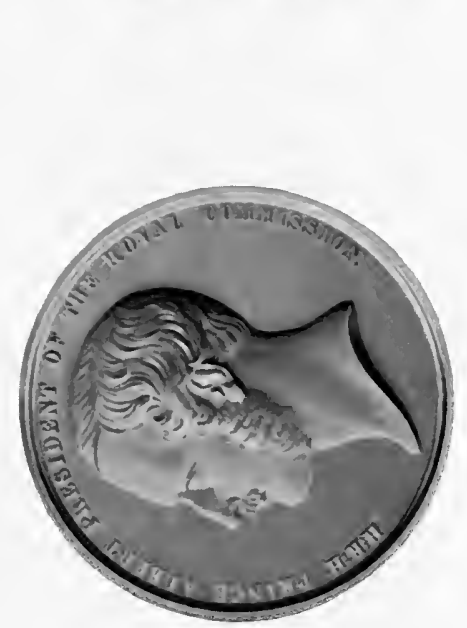

量

点

궁

䎑

崖

궁

동

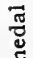

농 
that machine. The tables, however, were soon to be turned. Mr. Hussey arrived in England; a challenge having been given by the agents of Mr. McCormick, it was accepted by Mr. Hussey, and his English agent, Mr. Dray; and, after a fair contest before the Cleveland Society, at Middlesbro', near Stockton-on-Tees, on the 25th and 27th of September, a jury of twelve agriculturists pronounced a verdict in favor of the unmedalled machine. They decided that of the two machines, Hussey's had the preponderance of advantages-that it cut corn in the best manner, caused the least waste, did the most work in a given time, left the cut corn in the best order for gathering and binding, was the best adapted for ridge and furrow, was the least liable to get out of repair, and was the least price at first cost. On the two other points submitted to them, namely, which machine required the least amount of horse labor, and which the least amount of manual labor, the jury declined to express a decided opinion, in consequence of the state of the weather."

"There have been many other trials of Hussey's machine in different parts of the country, and the result has been so far uniformly satisfactory. Amongst these we have now to mention a very interesting one which took place by appointment last Saturday, at Windsor, in the 
presence of his Royal Highness, Prince Albert, originating in a correspondence between General Wemyss, on behalf of the Prince, and Messrs. Dray \& Co. of Swan-lane, the agents for Mr. Hussey. The spot selected for the trial was behind the statue of George III, at the end of the Long Walk, fern-of which there is an abundance in that locality-being the article on which the machine had to operate. The Prince having from an early hour in the morning been engaged in shooting in the vicinity of the statue, at half-past twelve, resigned his gun, and proceeded on horseback, in company with General Wemyss and Col. Seymour, Arrival of to the spot appointed for the trial of the mathe Prince chine. Dismounting from his horse, his Royal Highness saluted briefly and gracefully the assembled company, and especially Mr. Hussey and Mr. Dray. He then asked a few general questions respecting the history of the machine, and observed that as the ground selected was very uneven (it was in fact remarkably so) the trial would be a good one. After a brief delay, the gear being declared in order, on went the machine, drawn by two strong horses, and heedless of ruts and hillocks in its course, which was very rapid, bringing down every thing it encountered cleanly and completely, including two or three slices of turf at least a foot long, and more than an inch thick. 
"The performances of the machine were not confined to one single course. A considerable amount of work was performed in the most satisfactory manner, Mr. Hussey himself sitting on the box at the side, and throwing aside what was cut down in the manner best adapted for gathering and binding. Indeed the work was not confined to the fern; a rabbit which was not accustomed to this species of interference was startled and cruelly lacerated before it had time to escape.

"At the close of the trial, his Royal Highness gave a practical proof of his favorable opinion A Royal Order by ordering two of the machines for himself, one for Windsor and the other for Osborne. He then, after expressing his gratification, rode back to the game-keepers and resumed his gun. After he had left, the machine operated well upon some rushes.

"It may not be out of place to state here that Mr. Dray's explanation of the failure of the Hussey machine at Tiptree Hall (Mr. Mechi's farm) is that it was entirely owing to its not being properly managed. On that occasion, he says, the person in charge of it was simply a porter at the Exhibition, who, not understanding the matter, neglected to clear away the wheat as it was cut down, in consequence of which the action of the machine was unavoidably and fatally impeded. We wit- 
nessed the result at Mr. Mechi's, and certainly there was no such fault on Saturday. The progress of the machine was notwithstanding the unevenness of the ground, rapid and satisfactory; and it was stated as a fact that on a level ground the horses used in drawing may trot, not only without weakening or impeding the action of the knives, but even with advantages, as by that means the cutting requires increased precision and force."

The following is Prince Albert's certificate:

"Windsor Castle, Nov. 13, 1851.

"Sir-In answer to your letter addressed to Gen. Wemyss, I have received the commands of his Royal Highness, Prince Albert, to say, that so far as he could judge of Mr. Hussey's A Royal Reaping Machine, from its performance in the Verdict high fern at Windsor Park, his Royal Highness is disposed to form a very favorable opinion of it, and has ordered one* in consequence for the use of his own farm. His Royal Highness can however give no opinion as to the relative merits of this machine in comparison with those of others which he has not seen at work.

"I have the honor to be, sir, your obedient servant,

\section{"GREY."}

* The Prince ordered two Machines, one for Windsor and one for Isle of Wight. 
From Maidstone \& South Eastern Gazette, October 21, 1851.

\section{WEST KENT AGRICULTURAL SOCIETY'S PLOUGHING MATCH.}

HUSSEY'S AMERICAN REAPER.

"A distinguishing feature at this society's meeting on Thursday, the 16th inst., was an exhibition of the capabilities of the above machine. The session of the year of course prevented a display of its powers on anything in the shape of grain, indeed great difficulty was found in procuring even a green crop on which to operate. Undaunted by this fact, the inventor was determined to show to the anxious hundreds assembled the extent of the advantages to be derived from the use of his reaper. At two o'clock the machine was set to work upon a field of clover, short and light (as may be supposed), where its performance was effectual as it possibly could be, exciting a considerable amount of surprise as well as gratification. It was then taken to a piece of marsh land, where clumps of stout rushes in many places were growing in thick masses, presenting the appearance of stunted grain. The machine passed over this marsh, cutting the rushes with the same facility as if it had been corn, leaving the stubble about four inches long and very regular, giving also a good representation of the manner in which the sheaves of wheat, 
etc., are usually delivered. Both these operations, but especially the latter, were considered severe contests of the capabilities of the machine. Taking all the circumstances into consideration, the performance was far beyond all reasonable expectations. It was a question whether the excellent work of the 58 competing ploughs, or the extraordinary novelty of Hussey's machine in operation, added most to the gratification of the large assemblage of the leading agriculturists of Kent."

From the Kentish Gazette, November 11, 1851.

"In addition to the interest naturally felt by all who live on and by the soil in its proper cultivation, there was an unusual degree of attraction in the fact that a reaping machine by Mr. Hussey (the celebrated American Machinist) would be tested upon seven acres of mustard adjoining the ploughing field. The reaping was commenced about twelve o'clock, and continued for a considerable period. The crop of mustard was wet, and by no means calculated to favor the experiment. It was, however, after the machine was properly arranged, cut down with great regularity; and at a speed equal to four miles an hour it traversed the circuit of the field, hewing its way through the mustard, quickly followed by a crowd of eager 
observers, whose wondering gaze exhibited at once their astonishment and admiration of its working. Occasionally the level of the cutters were altered, so as to leave a greater or less length of stubble, which evinced the accurate adjustment to which the machine could be brought. Some portion of it was taken to pieces, and the whole of the arrangements shown, which the farmers present displayed an eager anxiety to investigate, and many were the questions proposed, and satisfactorily answered by the talented inventor.

"We should mention that the undulation of the land does not impede its operations in the least-as it was well observed by a gentleman present, that where a cart could travel there this machine could also go, and complete its design. No previous acquaintance with its principle is necessary to be able to guide its operation, as was shown by Mr. Neame, Jr., who mounted the platform and discharged the functions appertaining to the party who removes the corn from the machine after it is cut, with the greatest ease and precision. Indeed the most unqualified approval was given by the gentlemen present, to the applicability of the reaping machine to the purposes for which it is designed. We have thus entered into minute particulars, because this is the first 
opportunity we have had of witnessing the results of such an experiment, attended as it was with every degree of satisfaction. Lord Sondes gave an order for one of the machines, and we understand that three or four orders were given in the course of the day.

"At the dinner which followed, the chairman gave 'Sir John Tyldon and the visitors.'

"Sir John Tylden, as a member as well as a visitor, replied to the toast, and in a jocular strain animadverted on the suffering of the farmers of Faversham, who were determined, like a celebrated regiment in the service, to 'die hard.' He alluded to the reaping machine of Mr. Hussey, which he characterized in contradistinction to that of Mr. McCormick's and all others, as the universal reaping machine, of which he spoke in highly approving terms, and passed a warm eulogium on its talented inventor, and the country he represented, which in the space of 80 years had risen from a wilderness to her now exalted position, and proud of her Anglo-Saxon blood." 



\section{THIS BOOK IS DUE ON THE LAST DATE} STAMPED BELOW. 


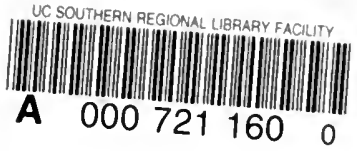


